\title{
Brackish to hypersaline facies in lacustrine carbonates: Purbeck Limestone Group, Upper Jurassic-Lower Cretaceous, Wessex Basin, Dorset, UK
}

\author{
Arnaud Gallois $^{1}\left[\right.$ D . Dan Bosence ${ }^{1} \cdot$ Peter M. Burgess ${ }^{2}$
}

Received: 15 September 2017 / Accepted: 8 March 2018 / Published online: 21 March 2018

(c) The Author(s) 2018

\begin{abstract}
Sedimentary facies and stratigraphic architecture of non-marine carbonates are controlled by a range of environmental parameters, such as climate, hydrology and tectonic setting, but the few published facies models do not account for this variability. Outcrop and petrographic observations from the Mupe Member of the Purbeck Limestone Group (Upper Jurassic-Lower Cretaceous) in Dorset, southern England, are the basis for new depositional models of non-marine microbialites and associated carbonates in an extensional basin. Ten facies are defined, described and grouped into five facies associations. The Mupe Member is characterised by accumulation of in situ microbial mounds developed around tree remains preserved as moulds and silicified wood. Mounds occur within three stratigraphic units, separated by three palaeosoils, characterised by less-porous, bedded, inter-mound packstone-grainstone that commonly onlap mound margins. Mounds are developed mainly in the shallowest areas of the lake, as indicated by their shapes, facies relationships and association with palaeosoils. These microbial mounds are compared to modern (Laguna Bacalar, Mexico and Great Salt Lake, Utah, USA) and ancient (Eocene Green River Formation, Uinta Basin, Utah, USA) analogues to assess their value as palaeoenvironmental indicators. Facies transitions indicate an earlier, brackish-water lake and a later hypersaline lake for the Mupe Member, both within a semi-arid climate setting in an extensional basin. The fact that the microbialites are covered by evaporitic strata, together with sedimentological, palaeontological and stable isotope data, suggest that there was a sharp change from through-flowing brackish-water, to a closed hypersaline, lacustrine system.
\end{abstract}

Keywords Non-marine carbonates · Lacustrine - Upper Jurassic-Lower Cretaceous · Microbialites · Purbeck Limestone Group · Facies transition

\section{Introduction}

Non-marine carbonates accumulate in basins where the deposition and facies distribution are controlled by a wide range of external factors such as climate, tectonics, source area lithologies, drainage systems and sediment input. Internal factors including hydrology, water-depth, nutrient levels and the ecology of carbonate producers (e.g. plankton, molluscs,

Arnaud Gallois

arnaud.gallois.2012@live.rhul.ac.uk

1 Earth Sciences Department, Royal Holloway, University of London, Queens Building, Egham Hill, Egham TW20 0EX, UK

2 School of Environmental Sciences, University of Liverpool, Jane Herdman Building, Liverpool L69 3GP, UK ostracods, algae and microbes) also play a major part (Platt and Wright 1991; Talbot and Allen 1996; Bohacs et al. 2000; Gierlowski-Kordesch 2010). Changes in lacustrine depositional environments and facies transitions can occur rapidly or over longer periods of time, both laterally and vertically, depending on the external controls involved (Platt and Wright 1991; Carroll and Bohacs 1999; Bohacs et al. 2000). The nature of such transitions can be gradual and interbedded or abrupt, within a conformable vertical succession and closely linked to lake-level fluctuations and/or climate/drainage system changes (Carroll and Bohacs 1999). However, there is still debate about the controls on these lake-level fluctuations and the sedimentological response to climatic change or modification of the tectonic regime (Platt and Wright 1991; Talbot and Allen 1996; Bohacs et al. 2000; Gierlowski-Kordesch 2010). Of particular importance for this study, Bohacs et al. (2000) proposed that transitions between lake types appear to be 
driven by climate in balanced-fill and overfilled lakes and by tectonics in underfilled lakes. This paper analyses the nature of the contact between the brackish and hypersaline facies of the lower Purbeck limestones to decipher the dominating external and internal controls on the depositional environment and the observed facies transitions.

Related to this is the question of the possible environmental significance of the occurrence of microbialites. Microbialites are common in lacustrine systems and the associated microbes typically colonise the shallowest areas of lakes with a variety of salinities, from hypersaline to freshwater, and set within various climates from tropical to temperate and from arid to humid (Dupraz et al. 2006, 2009; Della Porta 2015). Whereas there are many studies that indicate that different microbial fabrics occur in different sedimentary environments (e.g. Jahnert and Collins 2011, 2012; Chidsey et al. 2015), Della Porta (2015 p. 51) has recently stated in a large review of non-marine carbonate build-ups that "non-marine carbonate fabrics cannot be linked to a specific environment of deposition". These differing views have been expressed for the origin of microbial carbonates from the lower part of the Purbeck limestones in Dorset since original work by Webster (1826) who described "burrs" encasing in situ tree stumps in the Soft Cap bed at Lulworth Cove. Although originally interpreted as freshwater accumulations (Webster 1826; Buckland and De La Bèche 1835) these units were subsequently interpreted as stromatolitic and forming in hypersaline lagoons (West 1975; Francis 1982). However, more recent work has proposed formation in fresh- to brackish-water lakes (Bosence 1987) or freshwater lakes (Perry 1994). This paper also addresses this aspect by examining the sedimentological, palaeontological and isotopic characteristics of the microbialites and associated facies to assess depositional environments and, through comparison with present-day analogues, propose facies models.

The aims of this paper are: (1) to provide new data on ten non-marine carbonate facies and in particular on nonmarine microbial deposits; (2) to interpret these facies in terms of their depositional environments with the creation of two facies models, an earlier brackish-water lake and a later hypersaline water lake; (3) to discuss the different published interpretations of the environments of deposition of the Mupe Member of the Purbeck Limestone Group; and (4) to determine the nature of the contact and the processes that controlled the transition from the brackish to hypersaline facies.

\section{Geological setting of the Purbeck Limestone Group in the Wessex Basin}

The Wessex Basin of southern England and northern France (Fig. 1) evolved as an extensional sub-basin within a much larger system of intracratonic Mesozoic basins that covered much of north-western Europe (Ziegler 1982; Underhill and Stoneley 1998). These basins were inverted during Cenozoic times by south to north directed compression. The original extent of the Wessex Basin has been compiled from both surface outcrop and subsurface data (Fig. 1; Lake 1985; Cope et al. 1980; West 1992; Underhill 2002) and occasional marine connections have been suggested to the southwest and the northeast (Casey 1963; Cope et al. 1992). The Wessex Basin comprises three sub-basins: the Portland-Wight to the south-west (the subject of this paper), the Pewsey to the north-west and the Weald to the east (Underhill and Stoneley 1998) (Fig. 1b).

Deposition in the Wessex Basin is recorded in sandstones, shales, limestones and evaporites ranging from the Permian through to the Cenozoic, where deposits occur in the successor Hampshire Basin, following Cenozoic inversion (Fig. 2; Underhill and Stoneley 1998). The subject of this paper, the Purbeck Limestone Group, occurs within the PermianLower Cretaceous syn-rift megasequence (Underhill and Stoneley 1998).

The Purbeck Limestone Group comprises Upper Jurassic to Lower Cretaceous non-marine carbonate, evaporite and palaeosoil facies (West 1975; Bosence 1987; Perry 1994). The Mupe Member of the Purbeck Limestone Group, the subject of this paper, is particularly well exposed in its type area along the southern Dorset coast (Fig. 1c) as part of the Jurassic Coast World Heritage Site. The non-marine Mupe Member deposits (Fig. 2) have been studied intermittently over nearly 200 years, and most publications focus on the middle and upper parts of the group that are well exposed in Durlston Bay (e.g. Wimbledon and Hunt 1983; Clements 1993; Horne 2004; Riboulleau et al. 2007).

There have been fewer studies on the details of the lower part of the Mupe Member (Westhead and Mather 1996) that comprises the "Caps" and "Dirt Beds", the "Broken Beds" and the "Cypris Freestone" of earlier authors (Austen 1852; Arkell 1933; House 1969; Clements 1993). Notable exceptions are West $(1975,1979)$ and Francis $(1982,1983,1984$, 1986).

\section{Materials and methods}

This work is based on examination and logging of successions at 22 localities (Fig. 1c), preparation of 228 slabbed specimens and thin-sections for classic petrography and microscopy. Cathodoluminescence (CL) was also used to identify diagenetic phases, using a Technosyn Cold Cathode Luminescence Model 8200 Mk II coupled to an Olympus microscope $\mathrm{BH} 2$ and to a digital camera Zeiss MRc5. Facies descriptions are based on integrated field observations, slabbed specimens, and thin-section microscopy (Table 1). 


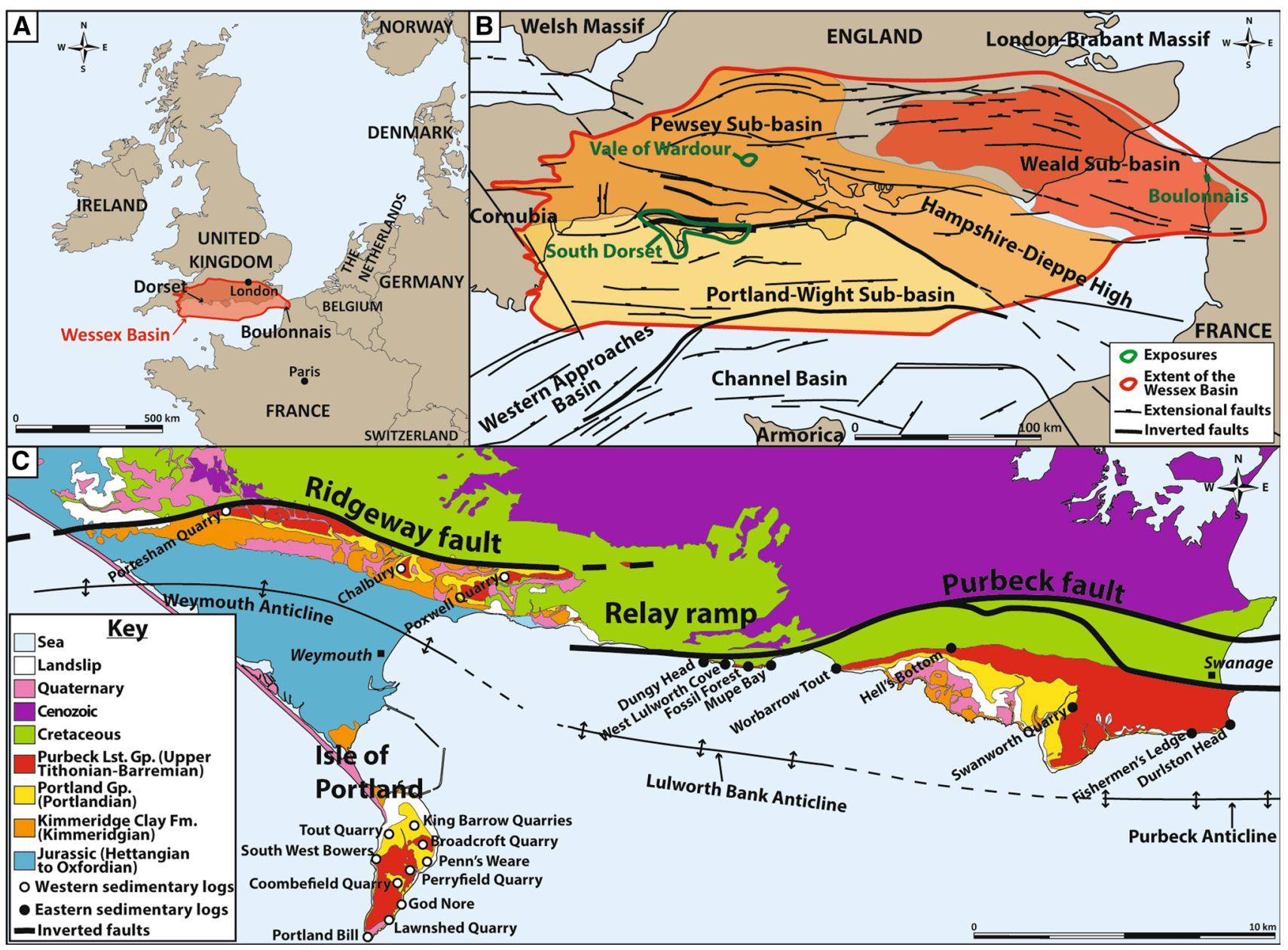

Fig. 1 Location and geological setting. a Purbeck Limestone Group exposures in UK and France. b Structural map of the Channel and Wessex Basins and sub-basins. The thick lines identify Mesozoic extensional faults inverted during the Alpine orogeny. c Simplified geological map of south Dorset with inverted faults (bold black lines) and associated anticlines. Locations of sedimentary logs measured in this study are labelled as dots. The white dots indicate the western logs and the black dots indicate the eastern logs used for the quantitative analysis of facies transitions
Quantitative analysis of facies transitions was carried out following the methods described in Burgess (2016).

\section{Facies description and succession}

Ten facies have been established within the Mupe Member and the details of the facies and their palaeoenvironmental interpretations are given in Table 1 and Figs. 4, 5, 6, 7, 8, 9, 10, 11, 12, 13, 14, 15. The generalised $\log$ (Fig. 3) for the Mupe Member shows characteristic facies of each of the named beds. Although not of formal lithostratigraphic status, the bed names (Fig. 2b), originating from quarrymen's terms, have been used in the geological literature for over 150 years.

The succession has a fine-grained horizon (Wackestone to fine grainstone facies, Fig. 9, Table 1) overlain by three horizons of mound-forming microbial deposits (Microbialite facies divided into Thrombolite and Stromatolite, and an unusual Burrow boundstone facies, Figs. 4, 5, 6, Table 1) that are interbedded and surrounded by the inter-mound facies (Intraclastic peloidal packstone-grainstone, Fig. 7, Table 1) and capped by three palaeosoils (Conglomerate and Carbonaceous marl facies, Figs. 12, 13, Table 1). These are overlain by either evaporitic horizons (Evaporite facies divided into Evaporite vuggy and Evaporite breccia subfacies, Figs. 14, 15, Table 1) or packstone to grainstone horizons (Cross-bedded peloidal packstone-grainstone, Fig. 8, Table 1). These two lithologies are interbedded with a Gypsiferous peloidal packstone (Fig. 10, Table 1) and Calcareous sandstone horizons (Fig. 11, Table 1).

The facies succession and bed transitions are described below in stratigraphic order. The Transition Bed (West 2013) erosively overlies the Portland Group at the base of the 


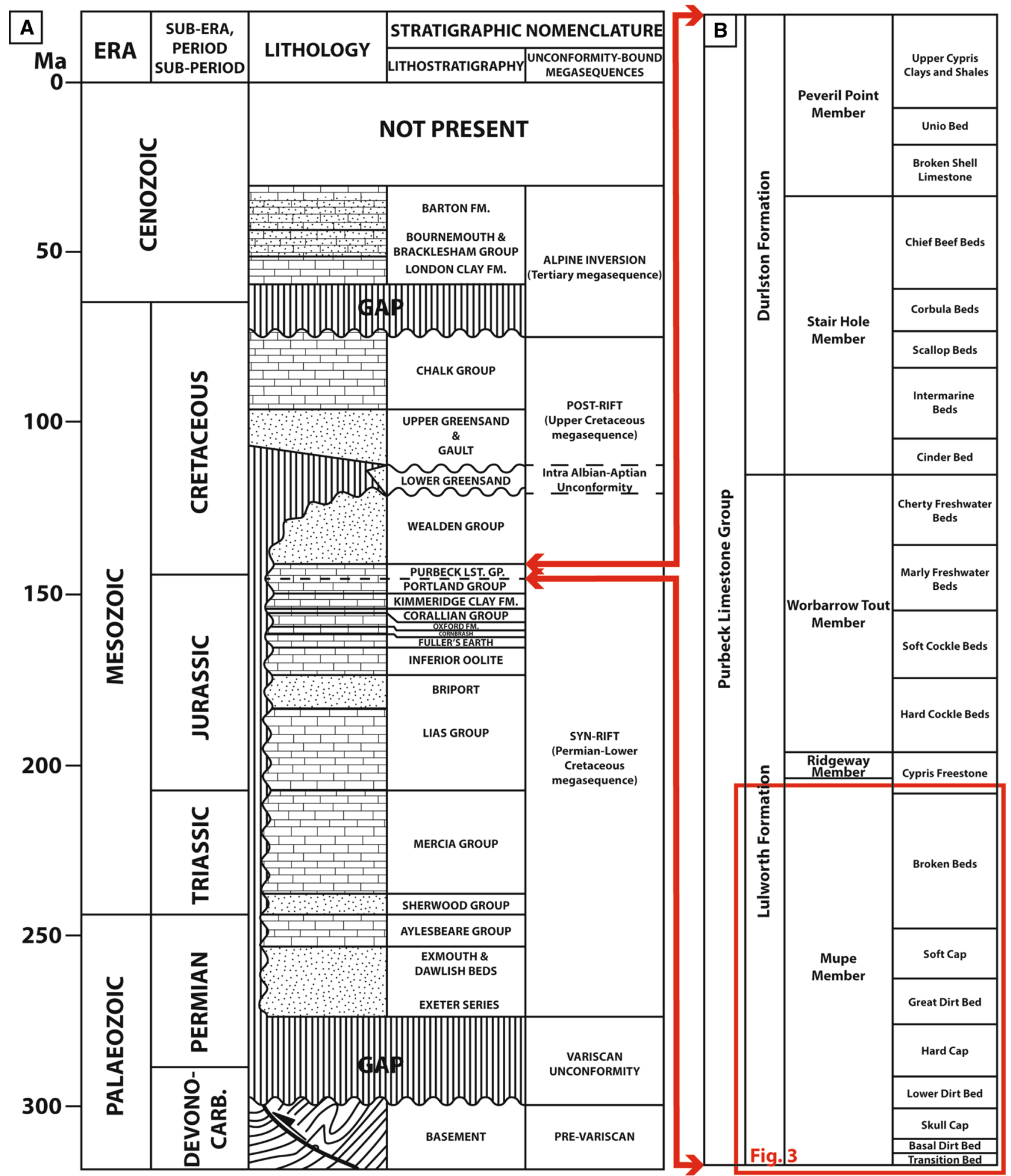

Fig. 2 Stratigraphic divisions of the Wessex Basin. a Stratigraphy of the Wessex Basin (modified after Underhill and Stoneley 1998). b Detailed stratigraphy of the Purbeck Limestone Group as used in this study. Formation names from Casey (1963); member names from Westhead and Mather (1996); bed names from Fisher (1856), Bristow (1857), Strahan (1898), Francis (1982) and West (2013) 


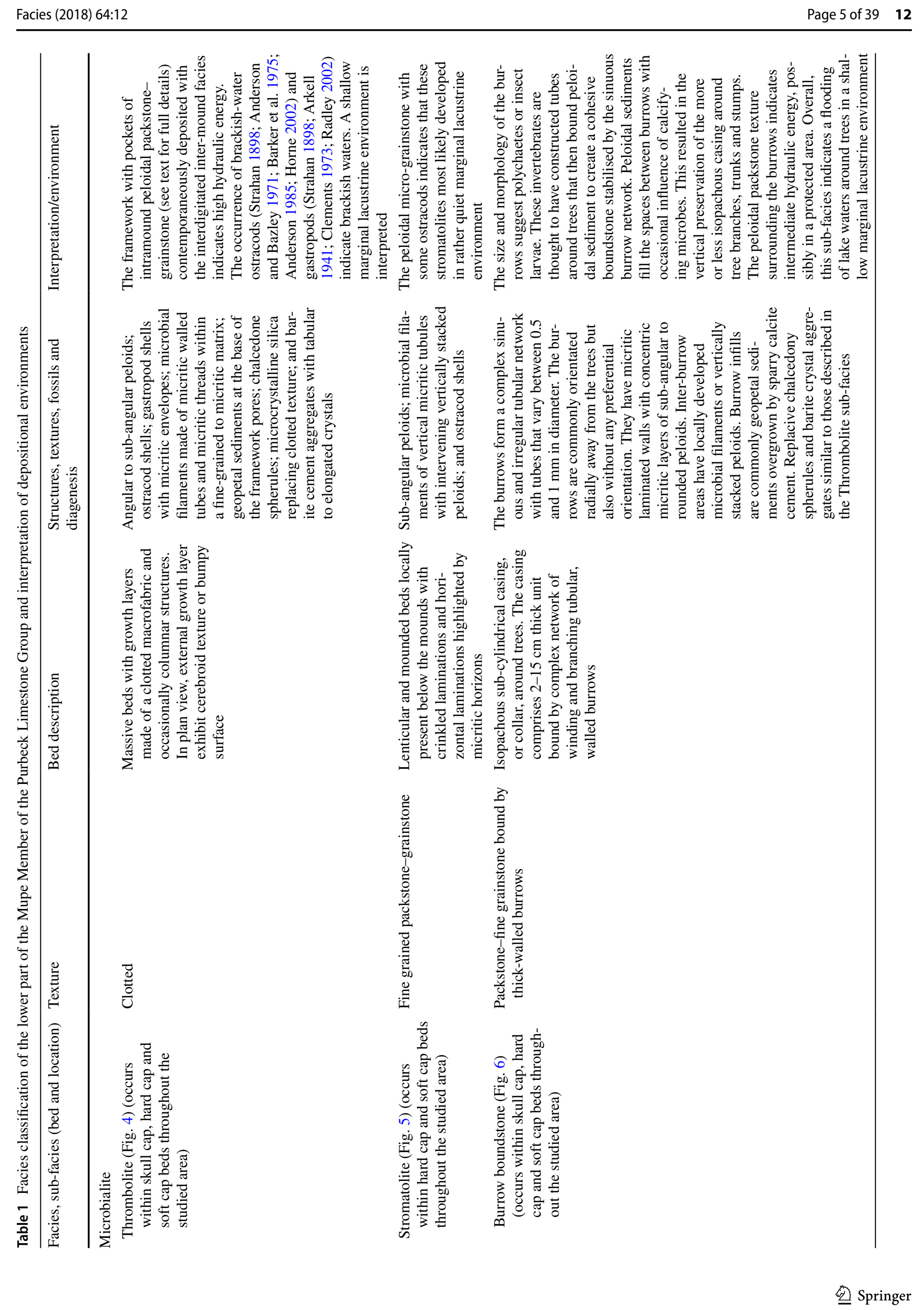




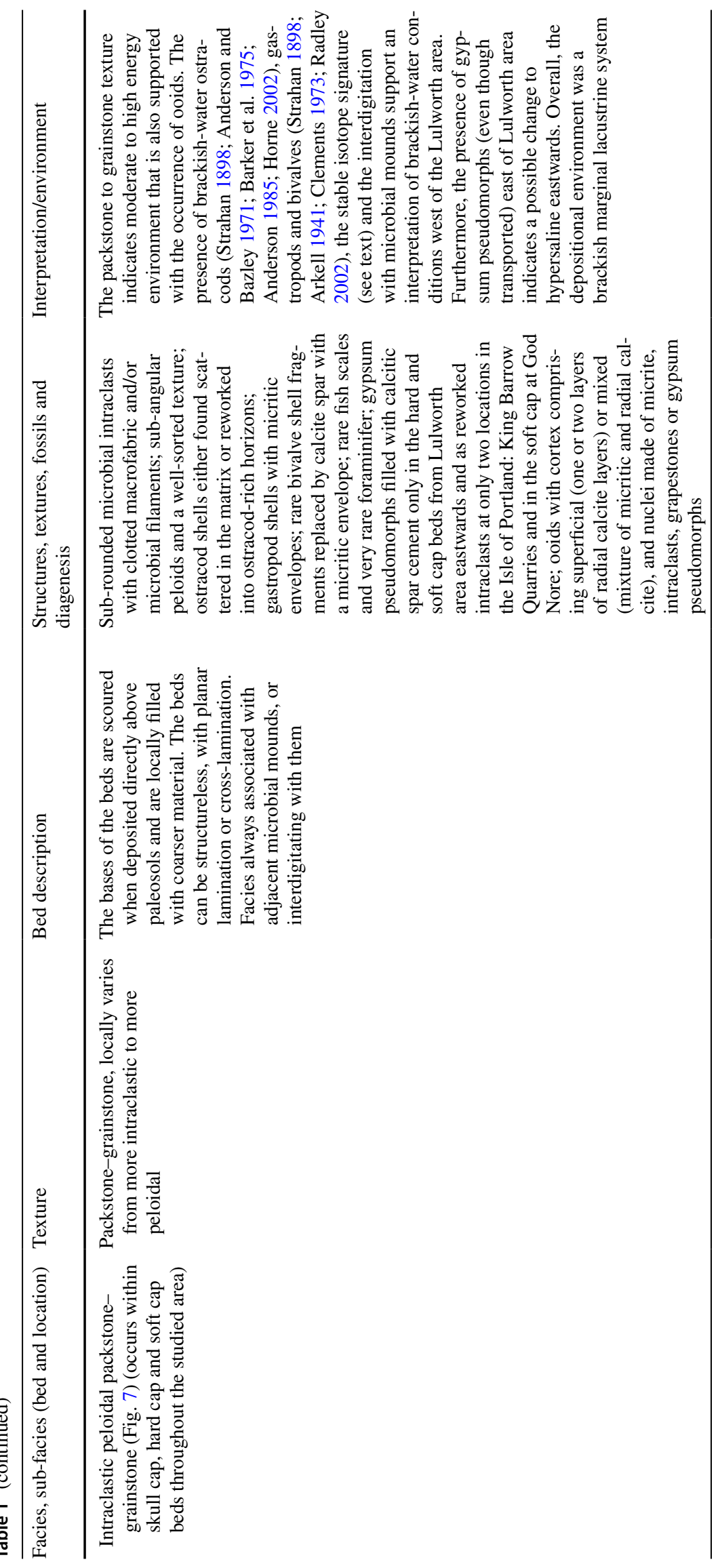




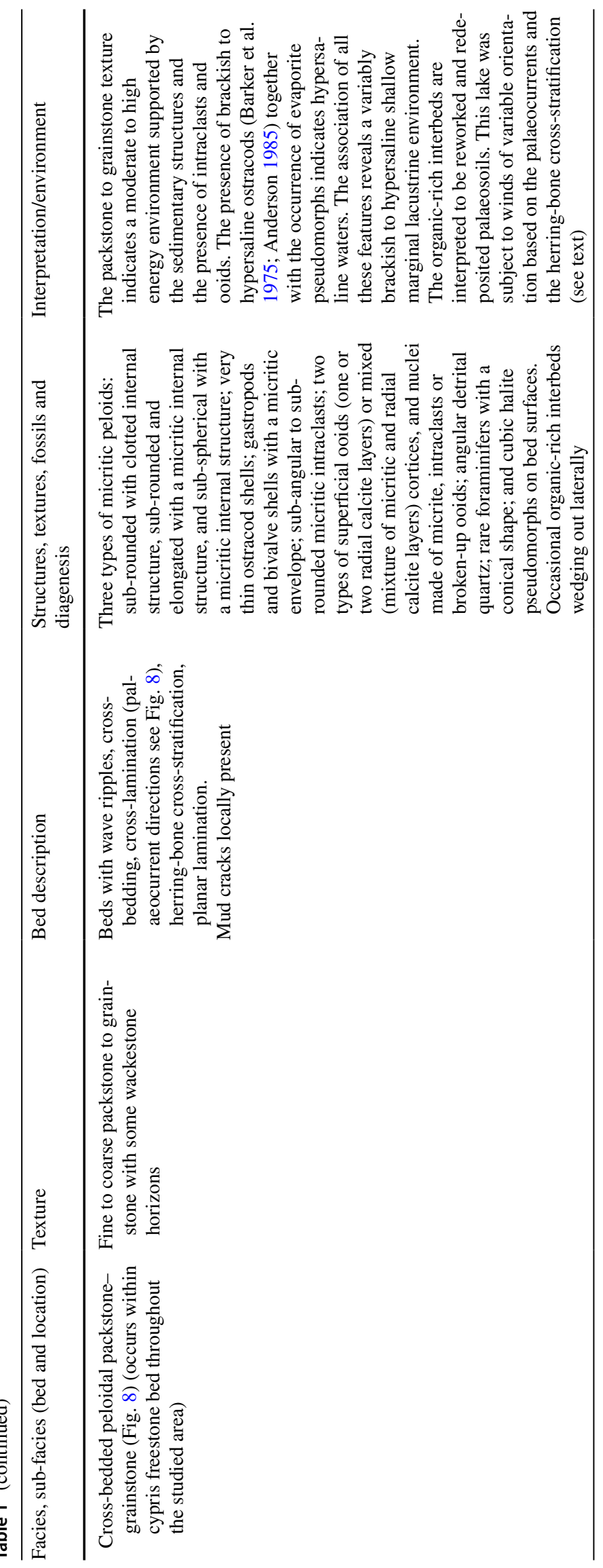




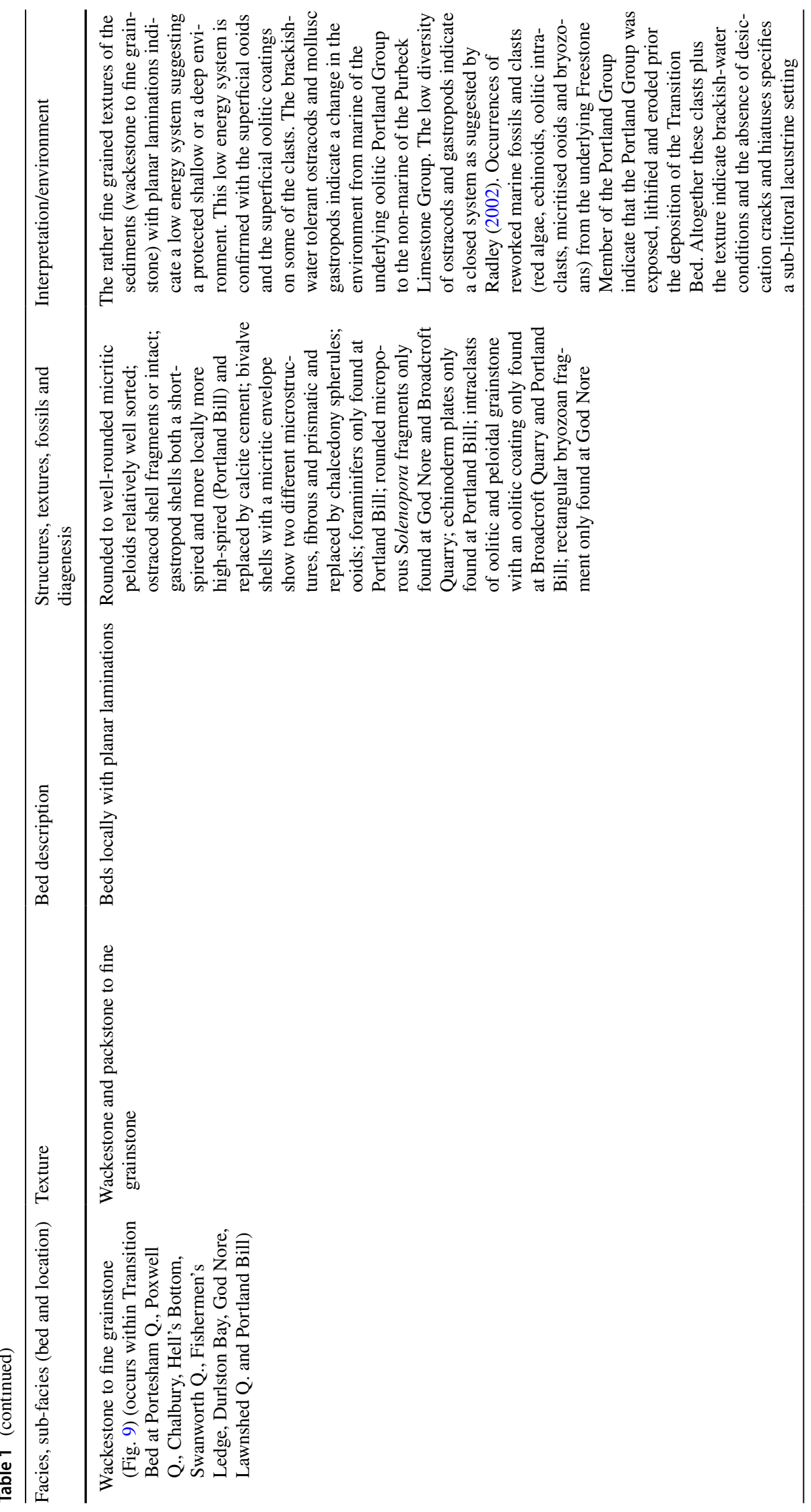




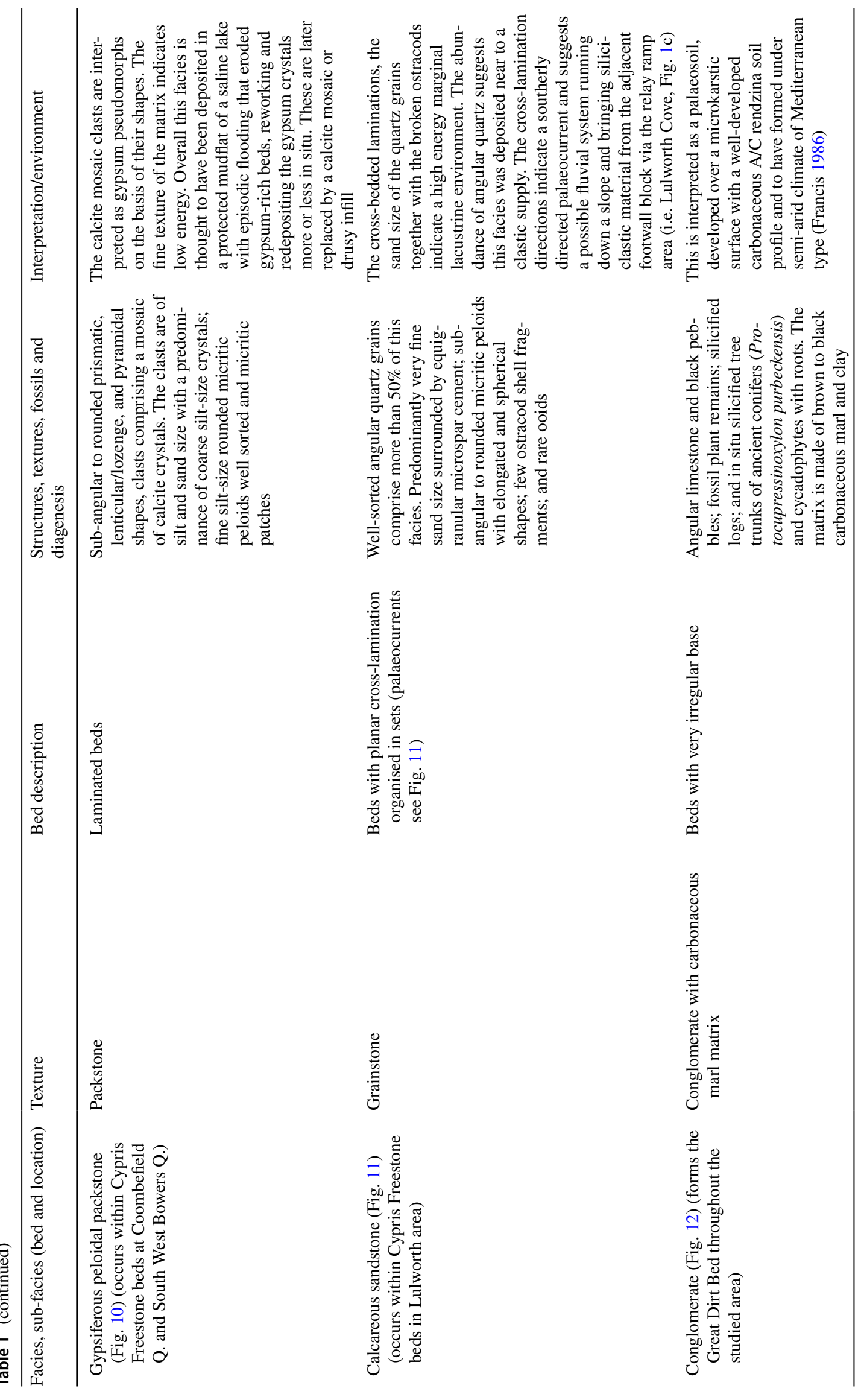




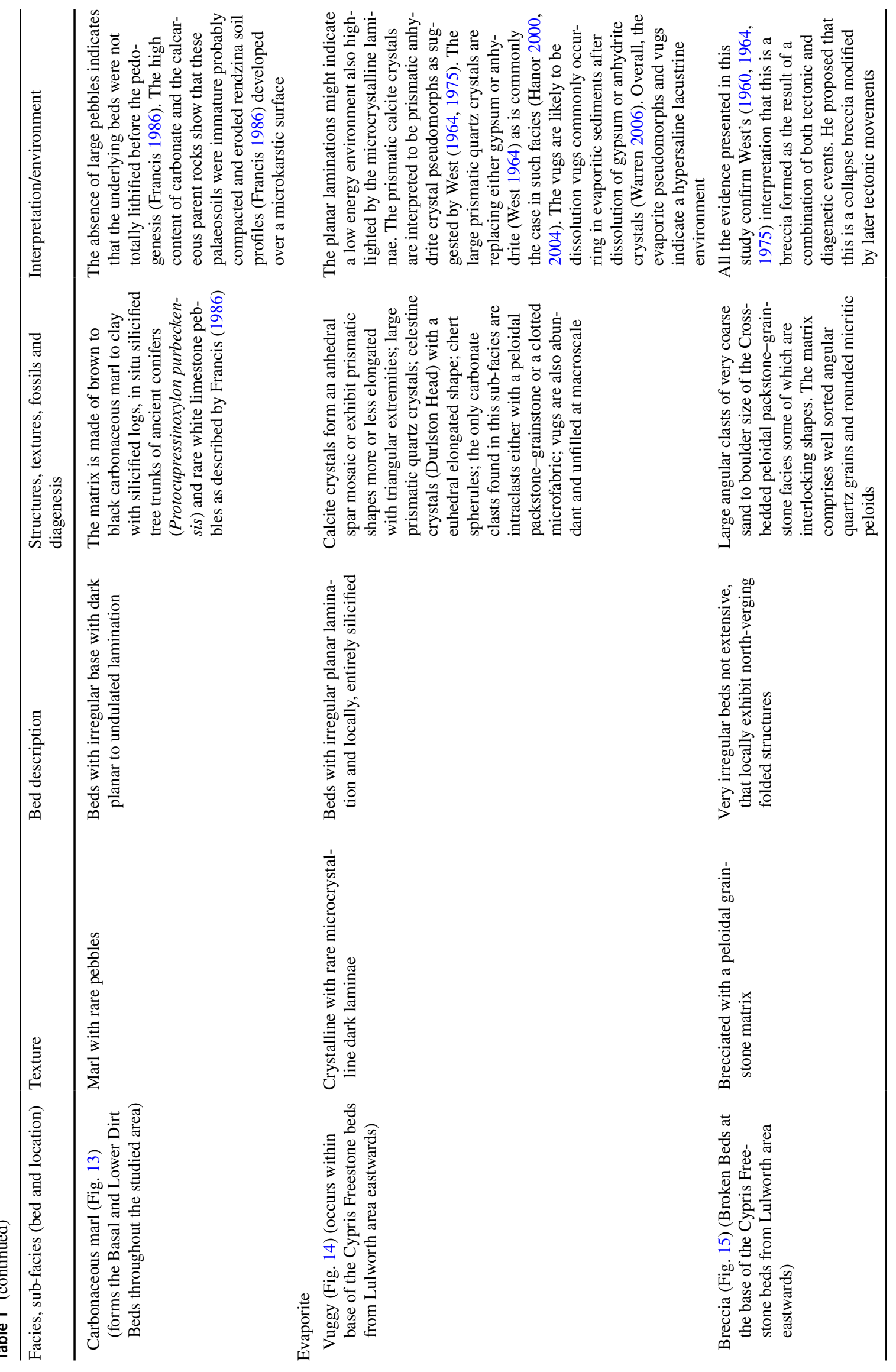


Fig. 3 Idealised log for the lower Mupe Member of the study area indicaring beds and facies as classified in this paper (Table 1), and drawn with average thicknesses of each bed (based on 22 sedimentary logs, Fig. 1). $M$ mudstone, $W$ wackestone, $F$ floatstone, $P$ packstone, $G$ grainstone, $R$ rudstone, $B$ boundstone, $C$ crystalline

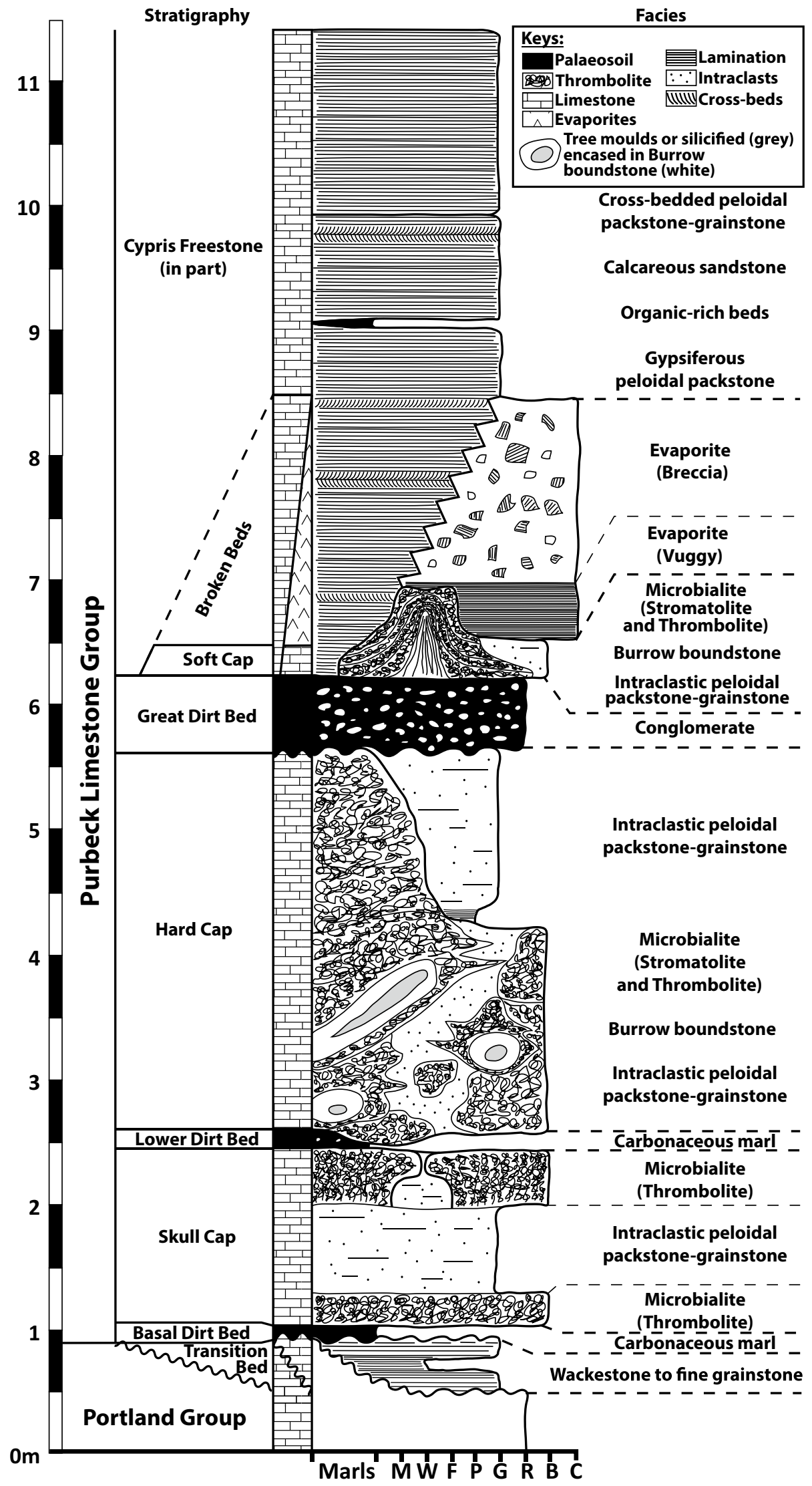



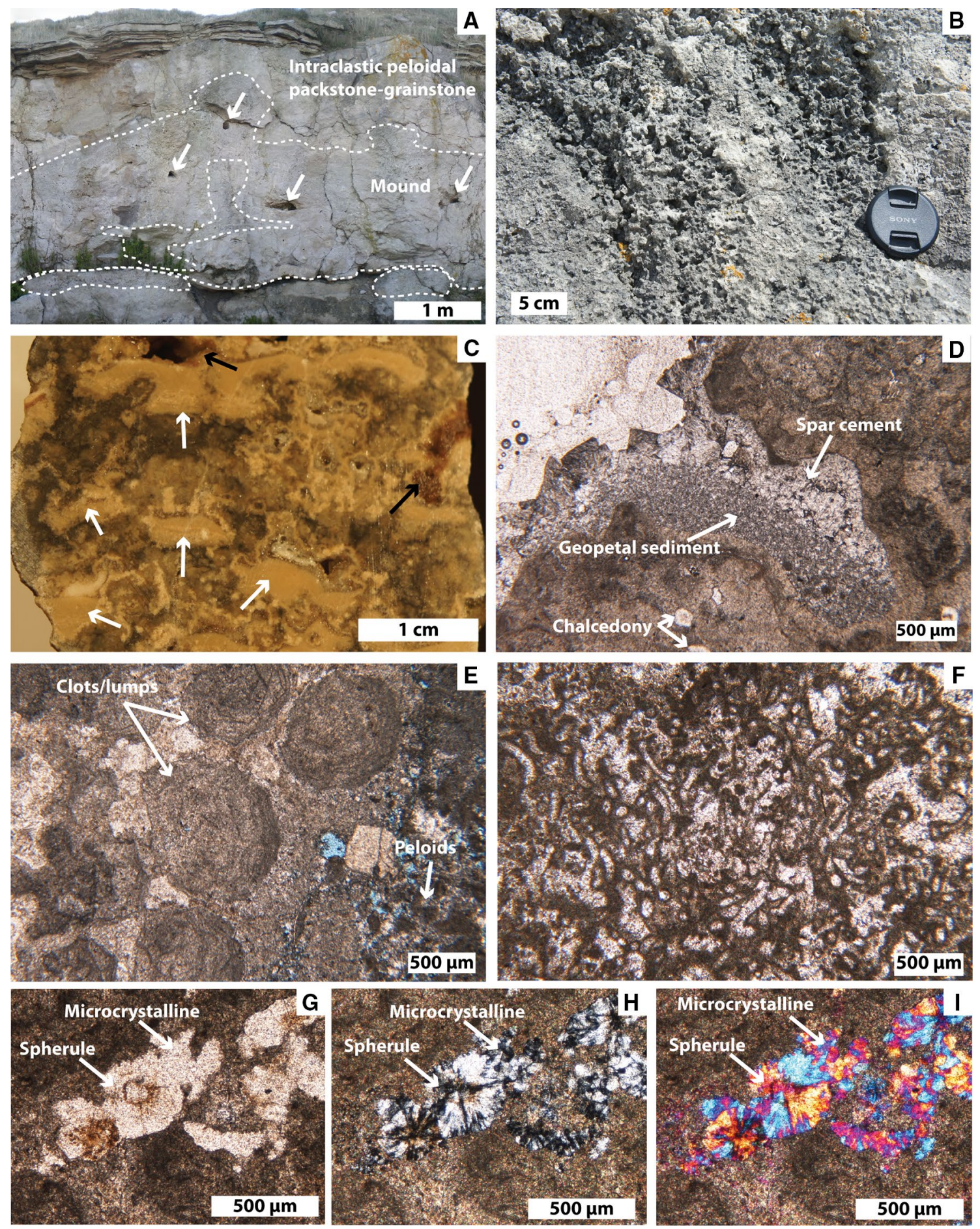

Purbeck Limestone Group and comprises the Wackestone to fine grainstone facies (Figs. 3 and 9, Table 1). The Basal Dirt Bed (Francis 1982) is an immature rendzina palaeosoil labelled as the Carbonaceous marl facies (Fig. 13) with an erosional surface at its base (Fig. 3). The Skull Cap (Damon 1860) comprises the Thrombolite sub-facies (Fig. 4) and the Intraclastic peloidal packstone-grainstone (Fig. 7). The base of the Skull Cap is a sharp, planar surface over the Basal
Dirt Bed (Fig. 3) and then comprises flat-topped microbial mounds before the transition in the middle part of the Skull Cap to the Intraclastic peloidal packstone-grainstone facies. This unit is overlain by tabular-shaped thrombolitic microbial mounds (Fig. 3). The Lower Dirt Bed (Damon 1860 ) is also interpreted by Francis (1986) as an immature rendzina palaeosoil made of the Carbonaceous marl facies resting on an erosional base (Fig. 3). The overlying Hard 
4Fig. 4 Thrombolite sub-facies. a Cross section of a mound with ca. 10-cm-wide tree (i.e. trunk and/or branch) holes (white arrows) and inter-mound bedding of Intraclastic peloidal pack-grainstone facies (Hard Cap, God Nore, Isle of Portland, 50³1'31.41"N; $\left.2^{\circ} 26^{\prime} 22.51^{\prime \prime} \mathrm{W}\right)$. b Clotted structure and irregular branches in Thrombolite sub-facies (Soft Cap, Fossil Forest, 50³6'58.37"N; $2^{\circ} 14^{\prime} 23.09^{\prime \prime} \mathrm{W}$ ). c Geopetal sediment (white arrows) and later barite crystals (black arrows) infilling framework pores (SH1, Sand Hole, Isle of Portland, 50 $\left.31^{\prime} 22.42^{\prime \prime} \mathrm{N} ; 2^{\circ} 36^{\prime} 34.58^{\prime \prime} \mathrm{W}\right)$. d Geopetal sediments filling growth framework cavity in mounds in plain polarised light (PPL, CQ2, Skull Cap, Coombefield Quarry, Isle of Portland, $50^{\circ} 31^{\prime} 58.25^{\prime \prime} \mathrm{N} ; 2^{\circ} 26^{\prime} 33.65^{\prime \prime} \mathrm{W}$ ). e Clots/lumps near the external surface of thrombolite framework (in PPL, BQ8, Broadcroft Quarry, Isle of Portland, 50 $32^{\prime} 53.74^{\prime \prime} \mathrm{N} ; 2^{\circ} 25^{\prime} 35.07^{\prime \prime} \mathrm{W}$ ), mound on the left and peloidal grainstone (i.e. inter-mound) on the right. f Filaments from thrombolite head (HB6, Hell's Bottom, 50³7'11.60"N; $\left.2^{\circ} 6^{\prime} 54.88^{\prime \prime} \mathrm{W}\right)$. g-i Silica spherules in micritic fabric in PPL (g); Cross-polarised light (XPL) (h) showing the extinction crosses centred in the spherules and the straight extinction in the microcrystalline silica; and (i) with gypsum plate showing a positive retardation in the NE and SW quadrants and negative in the NW and SE quadrants indicating typical extinction of quartzine or length-slow chalcedony (WLC3, West Lulworth Cove, 50³7'1.27"N; $2^{\circ} 14^{\prime} 55.18^{\prime \prime} \mathrm{W}$ )

Cap (Francis 1983) has a planar contact with the marl and comprises the mound-forming microbialite (Stromatolite and Thrombolite sub-facies, Figs. 3, 4 and 5) and Burrow boundstone facies (Fig. 6) that inter-digitate laterally with the Intraclastic peloidal packstone-grainstone facies (Fig. 3). The transition between the lower and upper part of the Hard Cap bed is marked by finer packstone that onlaps on to the sides of large microbial mounds (Fig. 3). The Great Dirt Bed (Damon 1860) is also interpreted by Francis (1986) as a rendzina palaeosoil made of the Conglomerate facies (Fig. 12) with an irregular (microkarstic) erosional surface at the base (Fig. 3). The overlying Soft Cap (Bristow 1857) comprises the third unit of Microbialite facies and Intraclastic peloidal packstone-grainstone facies with a planar surface at the base (Fig. 3). In this bed, the microbial mounds (Stromatolite and Thrombolite sub-facies and Burrow boundstone facies) developed around fallen trees and in situ tree stumps, as seen at the well-known Fossil Forest locality east of Lulworth Cove. Here, domed or doughnut-shaped build-ups, which interdigitate with the Intraclastic peloidal packstone-grainstone facies (detailed in the next section), are exposed in three dimensions. The overlying Cypris Freestone (Fisher 1856) beds comprise mainly the Cross-bedded peloidal packstone grainstone facies (Figs. 3 and 8) with intercalations of Gypsiferous peloidal packstone (Figs. 3 and 10) and Calcareous sandstone facies beds (Figs. 3 and 11). The basal surface is irregular, overlying the Soft Cap. The Cypris Freestone beds are overlain by the Hard Cockle Beds (Bristow 1857) that mark the top of the Mupe Member. In some locations, the base of the Cypris Freestone comprises the Broken Beds (Fisher 1856) that are made of the Evaporite breccia (Figs. 3 and 15) and vuggy sub-facies (Figs. 3 and 14) with an irregular and undulating surface at the base
(Fig. 3). The lower part of these beds is made of the Evaporite vuggy sub-facies that covers the microbial mounds of the underlying Soft Cap bed and is overlain by the Evaporite breccia sub-facies (Fig. 3).

\section{Quantitative facies transition analysis}

Quantitative facies transition analyses (Burgess 2016) were conducted for all logs from the western area and, separately, all $\log$ s from the eastern area (Figs. 1c and 16). Some facies were grouped to simplify the analysis (Fig. 16). The method defines optimised transition probability matrices that show the probabilities of all facies transitions recorded in all logs from each area, as well as the most optimal vertical arrangement of facies, analogous to an ideal cycle (Burgess 2016). Transition probability values range from zero to one. For example, no transitions occur from Evaporite to Carbonaceous marl, but Evaporites always pass upwards to Crossbedded peloidal packstone-grainstone facies. These variable transition probabilities suggest preferred occurrence of certain facies vertically and therefore laterally adjacent during deposition, assuming little or no missing time. This is clearly shown on the matrices and optimised successions (Fig. 16) where the Evaporite and Cross-bedded peloidal packstone-grainstone facies are interbedded and are expected to be deposited after all the other facies.

\section{Microbial mounds}

The Microbialite facies is subdivided into two sub-facies (Stromatolite and Thrombolite sub-facies), which together with the Burrow boundstone facies formed mounds, commonly around tree trunks, branches and/or stumps (Fig. 17). These mounds are composed of the Stromatolite sub-facies found locally and always at the base of the mounds (Fig. 17); the Burrow boundstone facies that forms a more or less isopachous casing around the tree remains (Fig. 17), and the major, mound-forming Thrombolite sub-facies that initially envelopes the Burrow boundstone and then accumulates upwards and laterally to form microbial build-ups (Fig. 17). The mounds are surrounded by, and inter-finger with, the Intraclastic peloidal packstone-grainstone facies (Figs. 7 and 17). This facies occurs as an inter-mound facies but also accumulates in growth cavities within the microbial mounds and between thrombolite heads and columns. Silicified tree remains (trunks, branches and stumps) are locally found in the Hard Cap and Soft Cap and were rooted in the Lower Dirt Bed and the Great Dirt Bed palaeosoils. Francis (1982, 1983) described and identified the trees to be an ancient cypress (Protocupressinoxylon purbeckensis).

Figure 18 illustrates the sequence of events interpreted for the origin of the microbial mounds and the 

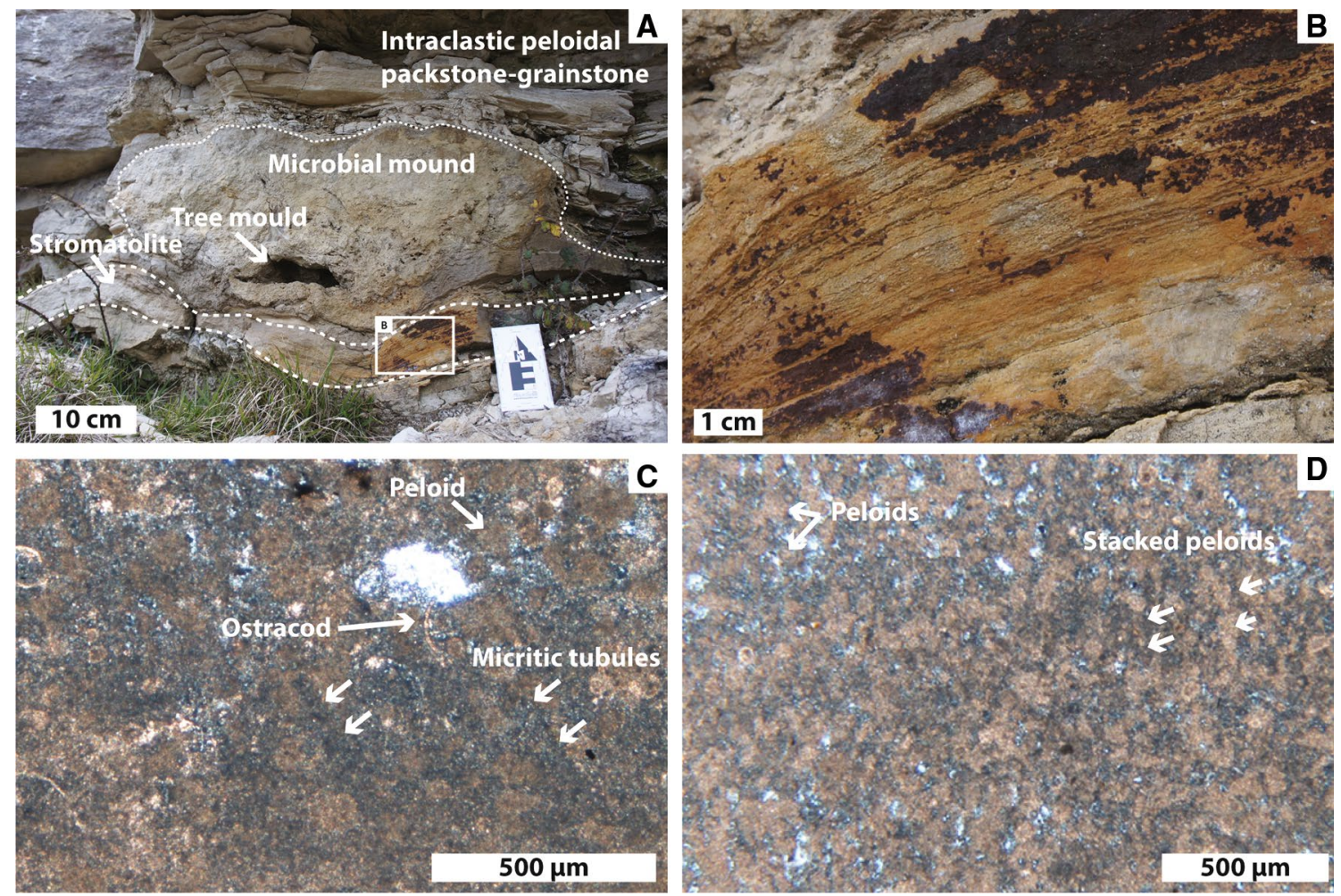

Fig. 5 Stromatolite sub-facies. a Hard Cap from Portesham Quarry with stromatolitic bed at the base $\left(50^{\circ} 40^{\prime} 18.03^{\prime \prime} \mathrm{N} ; 2^{\circ} 33^{\prime} 8.62^{\prime \prime} \mathrm{W}\right)$. b Crinkled lamination, close-up view of white boxed area in a. c Peloidal packstone with micritic tubules in PPL (SWB4, South West

silicification of the trees. Following the transgression of the lake, the Stromatolite sub-facies (Fig. 18e) accumulated on the lake floor and the soils and trees were waterlogged and killed (Fig. 18b-d), as originally proposed by West (1975) and Francis (1982). Following flooding, the Burrow boundstone facies was constructed around the trees being stabilised by non-marine polychaetes or insect larval tubes (Fig. 18e; Table 1) and locally by microbial filaments. Polychaetes and insect larvae are common in present-day lacustrine environments where they burrow into soft sediment. They create tubes by accreting grains they can find close by to consolidate burrow walls as well as using mucus to impregnate burrow walls (Leggitt and Loewen 2002; Paik 2005; Dashtgard and Gringas; Knaust and Bromley 2012). Contemporaneously with the deposition of the Burrow boundstone facies, the silicification of the wood tissue occurred (Fig. 18e). The silica is considered to be of biogenic origin from the dissolution of planktic organisms that were living in the brackish-water lake or phytoliths (cf. Bustillo 2010). Although diatoms are by far the most common biogenic silica source in the lacustrine environment, their first occurrence is in the Late Cretaceous (Chacón-Baca et al. 2002). Sponges are reported from the Jurassic in lakes (Manconi and Pronzato
Bowers, Isle of Portland, 50 $\left.32^{\prime} 40.06^{\prime \prime} \mathrm{N} ; 2^{\circ} 27^{\prime} 10.56^{\prime \prime} \mathrm{W}\right)$. d Peloidal grainstone with vertically stacked peloids in PPL (BQ4, Broadcroft Quarry, Isle of Portland, 50³2'53.74"N; ${ }^{\circ} 25^{\prime} 35.07^{\prime \prime} \mathrm{W}$ )

2008) and together with phytoliths that are very abundant in non-marine settings. They are the best candidate for the source of silica in the Purbeck lake. This dissolved silica is considered to have been remobilised as a molecular silicic acid $\left(\mathrm{H}_{4} \mathrm{SiO}_{4}\right)$, as that is the only form of soluble silica found in nature, and it is the only agent able to penetrate fine wood cells (Siever 1962; Francis 1982). This permineralisation by silicic acid was either a process of filling and impregnation as suggested by Leo and Barghoorn (1976) or the capillary and evapo-transpiration model of Renaut et al. (2002) to silicify in situ trees soon after their death (Fig. 18e, f). At this time, geopetal sediments were deposited in the tubular cavities of the Burrow boundstone facies (Fig. 18e). Francis (1982) measured preferential orientations in moulds of fallen trees in the Hard Cap and Soft Cap and interpreted northerly blowing winds due to their mainly north-south orientations. Relatively strong winds and/or wind-driven currents could have caused the broken-off upper parts of the trees to fall to the lake floor (Fig. 18f). In view of the Burrow boundstone casing around the trees, the broken-off portions are thought to have been heavier than the wood and unlikely to have formed long-distance drifts (Fig. 18f). These broken-off trees then formed the substrates for the accumulation of 

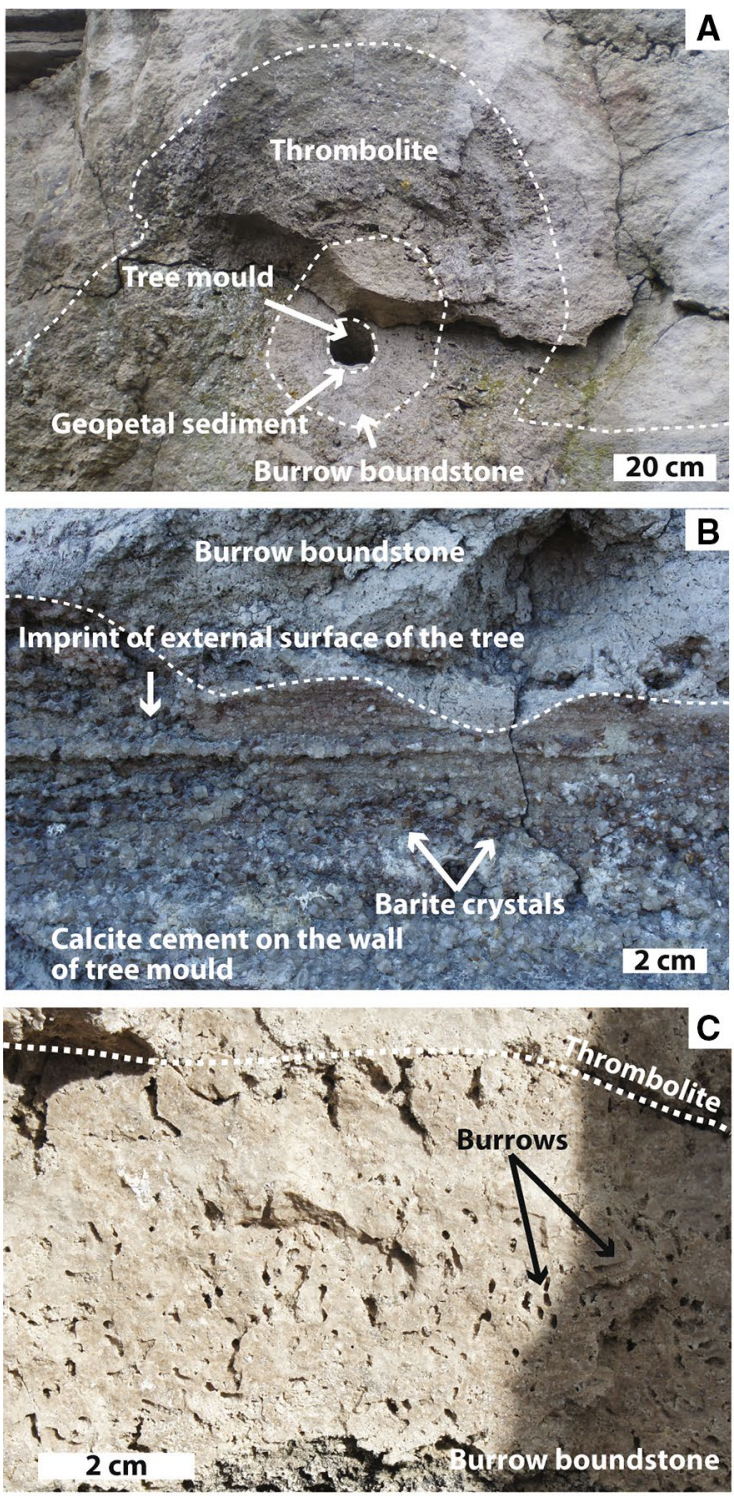

C
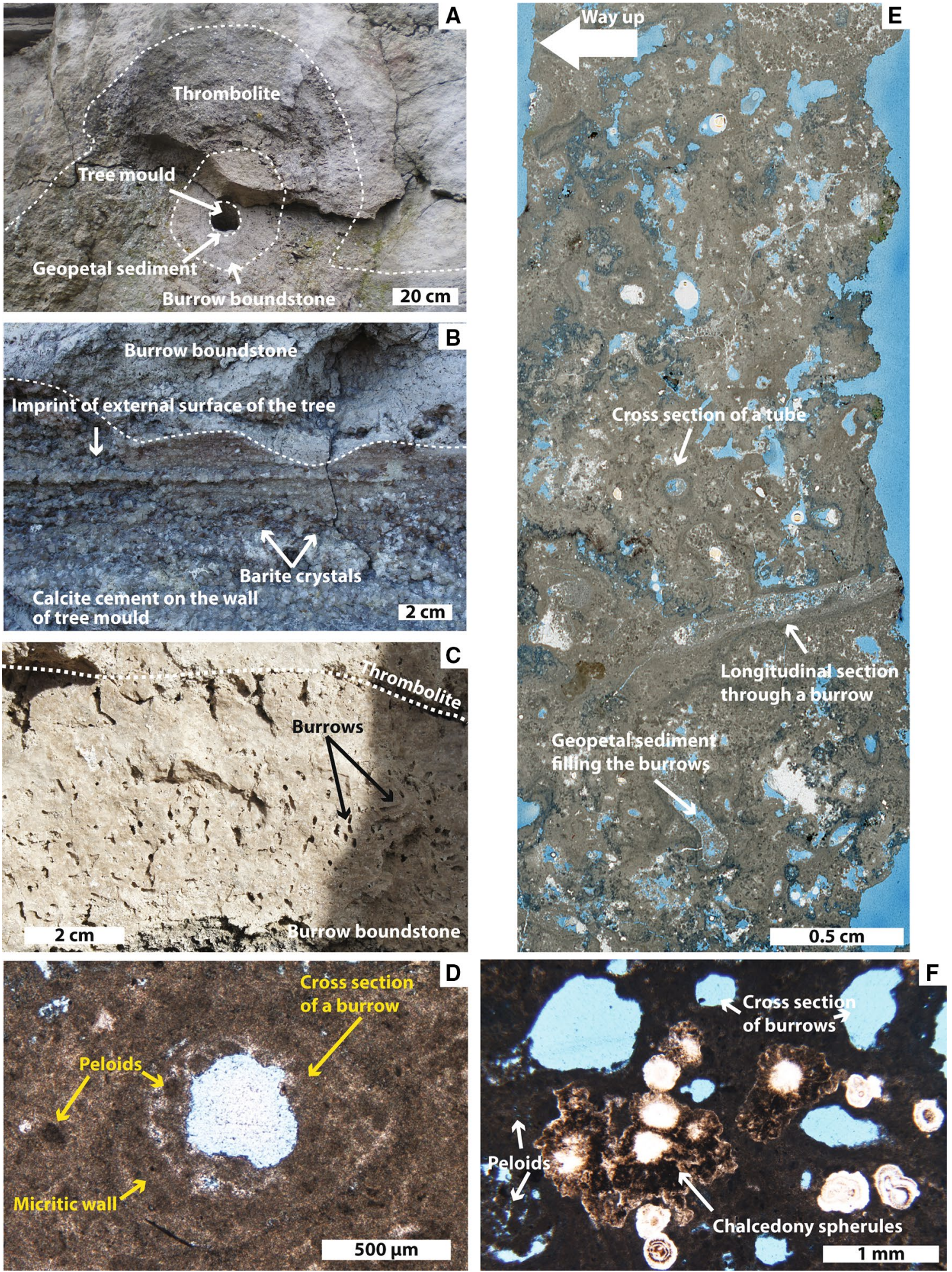

Fig. 6 Burrow boundstone facies. a Occurrence of the Burrow boundstone facies between tree (trunk or branch) moulds and Thrombolite sub-facies. b Burrow boundstone around tree (trunk or branch) mould with bark imprint, calcite cement and barite crystals (Hard Cap, God Nore, Isle of Portland, $50^{\circ} 31^{\prime} 31.41^{\prime \prime} \mathrm{N} ; 2^{\circ} 26^{\prime} 22.51^{\prime \prime} \mathrm{W}$ ). c Sinuous cavities interpreted as burrows as seen on quarry surface around tree mould (trunk or branch) mould (Soft Cap, Fossil Forest, $\left.50^{\circ} 36^{\prime} 58.37^{\prime \prime} \mathrm{N} ; 2^{\circ} 14^{\prime} 23.09^{\prime \prime} \mathrm{W}\right)$. d Burrow boundstone with cross

sections of thick-walled, tubular structures interpreted as burrows in PPL (BQ6, Broadcroft Quarry, Isle of Portland, 50³2'53.74"N; $\left.2^{\circ} 25^{\prime} 35.07^{\prime \prime} \mathrm{W}\right)$. e Thin-section scan illustrating the complex burrow network, burrow walls and geopetal sediment filling the tubes (BQ6, Broadcroft Quarry, Isle of Portland, 50 $32^{\prime} 53.74^{\prime \prime} \mathrm{N} ; 2^{\circ} 25^{\prime} 35.07^{\prime \prime} \mathrm{W}$ ). f Chalcedony spherules developing around peloids in micrite matrix in PPL (E251107, God Nore, Isle of Portland, $50^{\circ} 31^{\prime} 31.41^{\prime \prime} \mathrm{N}$; $\left.2^{\circ} 26^{\prime} 22.51^{\prime \prime} \mathrm{W}\right)$ 

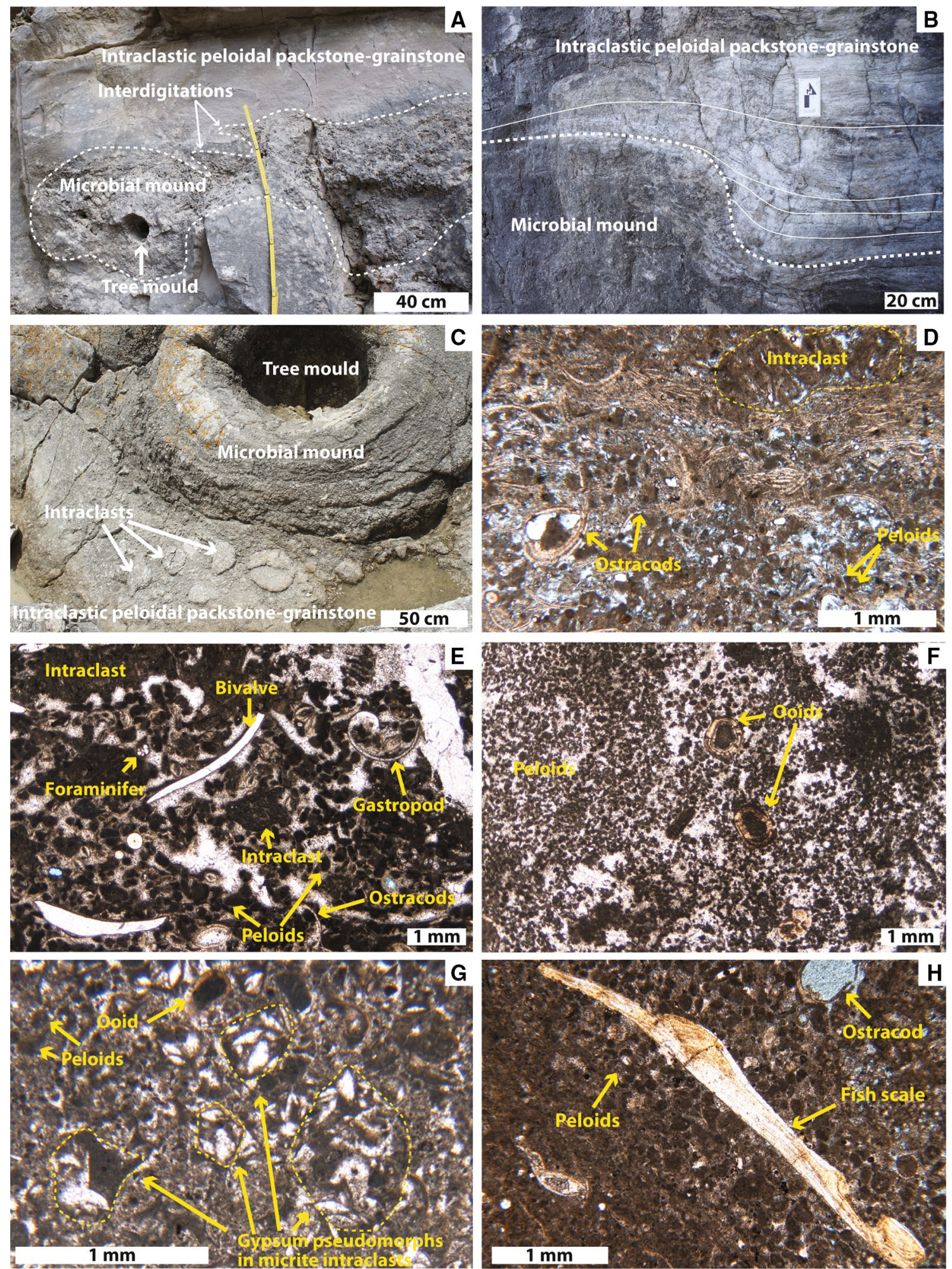

the Thrombolite sub-facies by photosynthetic cyanobacteria as they only developed on the upper surfaces of the fallen trees (Fig. 18g). This explains the non-isopachous morphology of the Thrombolite sub-facies around the trees (Fig. 18a, b, g). In the meantime, a second generation of geopetal sediments was deposited in the cavities of the Thrombolite sub-facies and in the tubes of the Burrow boundstone facies (Fig. 18g) (cf. Bosence 1987). Later during burial, calcite spar cements were precipitated followed by barite crystals (Table 1; Figs. 4c and 18g). 
४Fig.7 Intraclastic peloidal packstone-grainstone facies. a Interdigitation of a microbial mound and the Intraclastic peloidal packstone-grainstone facies. The dashed line outlines the boundary of the microbial mound (Tout Quarry, Isle of Portland, 50 $33^{\prime} 11.57^{\prime \prime} \mathrm{N}$; $2^{\circ} 26^{\prime} 36$. 83"W). b Onlap of plane-bedded Intraclastic peloidal packstone-grainstone (solid lines) onto margin of microbial mound (dashed line) (Fossil Forest, 50³6'58.37"N; 2 ${ }^{\circ} 14^{\prime} 23.09^{\prime \prime} \mathrm{W}$ ). c Centimetre-sized microbial intraclasts adjacent to a microbial mound (Fossil Forest, 50 $36^{\prime} 58.37^{\prime \prime} \mathrm{N} ; 2^{\circ} 14^{\prime} 23.09^{\prime \prime} \mathrm{W}$ ). d Intraclastic peloidal packstone-grainstone with ostracods, peloids, and intraclasts. Note the ostracod-rich horizon above (PPL, PQ3, Portesham Quarry, $\left.50^{\circ} 40^{\prime} 18.03^{\prime \prime} \mathrm{N} ; 2^{\circ} 33^{\prime} 8.62^{\prime \prime} \mathrm{W}\right)$. e Intraclastic peloidal grainstone with mollusc fragments (gastropods and bivalves), intraclasts, peloids, ostracods and rare foraminifer in PPL (WT3, Worbarrow Tout, $\left.50^{\circ} 36^{\prime} 55.95^{\prime \prime} \mathrm{N} ; 2^{\circ} 11^{\prime} 11.70^{\prime \prime} \mathrm{W}\right)$. f Fine-grained intraclastic peloidal grainstone with ooids and peloids in PPL (WLC5, West Lulworth Cove, $50^{\circ} 37^{\prime} 1.27^{\prime \prime} \mathrm{N} ; 2^{\circ} 14^{\prime} 55.18^{\prime \prime} \mathrm{W}$ ). g Gypsum pseudomorphs (lozenge-shaped) in micrite intraclasts (yellow dashed lines), peloids and ooids in PPL (MB5A, Mupe Bay, 50 $36^{\prime} 58.37^{\prime \prime} \mathrm{N} ; 2^{\circ} 13^{\prime} 42.20^{\prime \prime} \mathrm{W}$ ). h Peloidal packstone with a fish scale, ostracods and peloids (PQ7, Portesham Quarry, 5040'18.03"N; $2^{\circ} 33^{\prime} 8.62^{\prime \prime} \mathrm{W}$ )

\section{Facies associations and palaeoenvironments}

Five facies associations (FA) are defined on the basis of frequency of facies transitions, the interpreted palaeoenvironments of the facies and their occurrence in the field: Sub-littoral lacustrine, Emergent, Mounded marginal lacustrine, Hypersaline lacustrine and Bedded marginal lacustrine facies associations (Table 2).

\section{Sub-littoral lacustrine facies association}

The Sub-littoral lacustrine FA comprises just one rather distinct facies, the Wackestone to fine grainstone facies. This facies is exclusively found at the base of the Mupe Member in the Transition Bed (Table 2; West 2013). It comprises fine-grained peloids and ostracods and lacks sedimentary structures apart from locally developed planar lamination. In view of the fine-grained texture and the quasi-absence of sedimentary structures, this facies association is interpreted to have been deposited below wave-base, between metres and tens of metres of water depth with rare storm reworking to form lamination. On basis of the preserved biotas (brackish-water Valvata, Hydrobia, and Loriolina gastropods; freshwater Cyrena media bivalves, and ostracods), the depositional environment is interpreted as brackish-water lacustrine. The erosion of the underlying shallow-marine Portland limestones results in the presence of ooid grainstone intraclasts and marine bioclast fragments (Solenopora, bryozoans, echinoids, and bivalves) reworked into this facies.

\section{Emergent facies association}

This facies association is found in the three palaeosoils: Basal Dirt Bed, Lower Dirt Bed and Great Dirt Bed, and comprises the Carbonaceous marl and the Conglomerate facies (Table 2). The palaeosoils and their contents were documented in detail by Francis $(1983,1984,1986)$ who demonstrated that they have a rendzina profile (mature with profiles A/C for the Great Dirt Bed and immature for the Basal and Lower Dirt Beds). The palaeosoils contain rooted and fallen ancient conifers (Protocupressinoxylon purbeckensis, Francis 1983) together with cycadophytes (Fitton 1827; Buckland and De La Bèche 1835). The type of soil and the occurrence of conifer and cycad remains were used as evidence by Francis (1986) to interpret the climate semiarid Mediterranean-type. This is supported with the occurrence of fossil charcoal, or fusain (Francis 1986) and black pebbles as indicators of past forest fires (e.g. Strasser and Davaud 1983). The palaeosoils commonly accumulated over an irregular surface, interpreted as microkarstic; they have their thickest expression in palaeotopographic lows and are thin or absent over highs.

\section{Mound marginal lacustrine facies association}

The Mounded marginal lacustrine FA comprises the moundforming Microbialite and Burrow boundstone facies and the intermound Intraclastic peloidal packstone-grainstone facies. This facies association is found in all the locations studied, in the Skull Cap, Hard Cap, and Soft Cap (Table 2). The coarse-grained texture of these boundstones and grainstones indicates a moderate- to high-energy depositional environment and a marginal-lacustrine setting is interpreted. This is supported by its close association with karstic surfaces and palaeosoils (Fig. 16) and the presence of tabular and mounded, low-relief microbial mounds, which are interpreted to have grown to lake level in shallow water. The presence of brackish-water ostracods (Strahan 1898; Barker et al. 1975; Anderson 1985; Horne 2002) and gastropods (Strahan 1898; Arkell 1941; Clements 1973; Radley 2002), together with the absence of freshwater charophytes and in situ evaporite minerals suggests that this facies association represents a brackish-water lacustrine (i.e. non-marine) environment. This is supported by stable isotope (carbon and oxygen) data acquired during this project (Fig. 19; Dharmarajah 2015) from bulk samples from the Intraclastic peloidal packstone-grainstone of the Skull and Hard Cap from the Isle of Portland. The $\delta^{13} \mathrm{C}$ data vary between -2.71 and $-7.20 \%$ (with a precision of $0.12 \%$ ) and the $\delta^{18} \mathrm{O}$ data between -4.63 and $-0.72 \%$ (with a precision of $0.03 \%$; Fig. 19). Oxygen isotopic signatures of lacustrine carbonate precipitating in the water column, and accumulating 

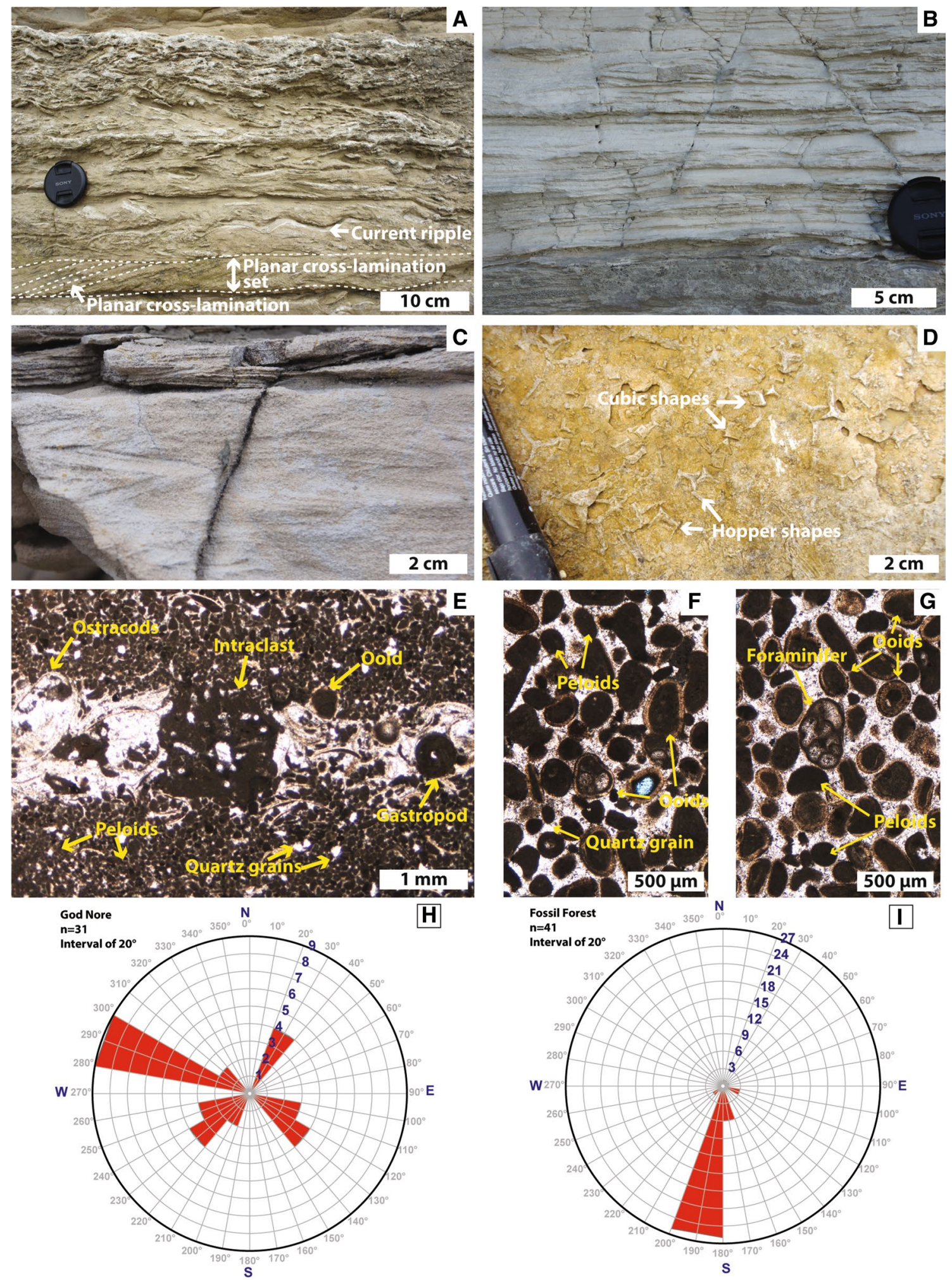

as mud, reflect lake water composition and temperature of precipitation; carbon values are controlled by the source of the $\mathrm{CO}_{2}$ /carbonate (Talbot and Kelts 1990; Leng and Marshall 2004; Tanner 2010). Considering that the Purbeck data

were obtained from bulk samples, their values will reflect a mixture of sedimentological and diagenetic signatures.

Arenas-Abad et al. (2010, Table 2), Della Porta (2015, Tables 1 and 2) and Talbot (1990, Fig. 1) presented isotopic values from abiotic lacustrine and fluvial carbonates and 
४Fig. 8 Cross-bedded peloidal packstone-grainstone facies. a Planar cross-lamination and wave or current ripples (vertical-section, Pondfield Cove, $50^{\circ} 36^{\prime} 57.12^{\prime \prime} \mathrm{N} ; 2^{\circ} 11^{\prime} 4.11^{\prime \prime} \mathrm{W}$ ). b Planar lamination (vertical-section, South West Bowers, 50 $32^{\prime} 40.06^{\prime \prime} \mathrm{N} ; 2^{\circ} 27^{\prime} 10.56^{\prime \prime} \mathrm{W}$ ). c Herring-bone cross-stratification (vertical-section, Fossil Forest, $\left.50^{\circ} 36^{\prime} 58.37^{\prime \prime} \mathrm{N} ; 2^{\circ} 14^{\prime} 23.09^{\prime \prime} \mathrm{W}\right)$. d Halite pseudomorphs on under surface of bed (Broadcoft Quarry, 50 32'53.74"N; 2²5'35.07"W). e Peloidal grainstone with peloids, ostracods, microbial intraclasts, quartz grains and gastropods (WLC8, West Lulworth Cove, $\left.50^{\circ} 37^{\prime} 1.27^{\prime \prime} \mathrm{N} ; 2^{\circ} 14^{\prime} 55.18^{\prime \prime} \mathrm{W}\right)$. f Close-up view of grainstone with peloids, quartz grains and superficial ooids with heavily micritised (possibly microbial) intraclasts and grapestone nuclei (WT12, Worbarrow Tout, $\left.50^{\circ} 36^{\prime} 55.95^{\prime \prime} \mathrm{N} ; 2^{\circ} 11^{\prime} 11.70^{\prime \prime} \mathrm{W}\right)$. g Peloidal grainstone with peloids, ooids and foraminifer (WT12, Worbarrow Tout, $\left.50^{\circ} 36^{\prime} 55.95^{\prime \prime} \mathrm{N} ; 2^{\circ} 11^{\prime} 11.70^{\prime \prime} \mathrm{W}\right)$. h Orientation and direction measurements of the cross-lamination at God Nore with 31 measurements showing a main current direction towards N290 and three secondary directions N030; $\mathrm{N} 130$ and $\mathrm{N} 230\left(50^{\circ} 31^{\prime} 31.41^{\prime \prime} \mathrm{N} ; 2^{\circ} 26^{\prime} 22.51^{\prime \prime} \mathrm{W}\right)$. i Orientation and direction measurements of the cross-lamination at Fossil Forest with 41 measurements showing a unique direction towards N190 $\left(50^{\circ} 36^{\prime} 58.37^{\prime \prime} \mathrm{N} ; 2^{\circ} 14^{\prime} 23.09^{\prime \prime} \mathrm{W}\right)$

Lovelace (2006) values for an Upper Jurassic freshwater lake of the Morrison Formation (Wyoming, USA); these are compared to the Purbeck analyses in Fig. 19. The $\delta^{13} \mathrm{C}$ data of the Skull and Hard Caps are within the range of fluvial and freshwater lacustrine environments (Fig. 19). The negative values suggest depletion in ${ }^{12} \mathrm{C}$ due to photosynthesis and/ or constant renewing of surface waters, which indicates an increasing vegetation cover and/or a short-residence time of the waters (Talbot 1990; Talbot and Kelts 1990; Leng and Marshall 2004). The $\delta^{18} \mathrm{O}$ data are within the range of saline and hypersaline lakes (Fig. 19). This suggests depletion in ${ }^{16} \mathrm{O}$ due to evaporation of lighter isotopes, which indicates fresh (but not truly freshwater) to brackish waters in a through-flowing system (Talbot 1990; Talbot and Kelts 1990; Leng and Marshall 2004). In addition, sparry drusy calcite cements are identified in most thin-sections and these are thought to have formed shortly after deposition during early diagenesis. These cements would have been sampled during isotope measurements, and account for the depletion of ${ }^{16} \mathrm{O}$. However, the fluids that precipitated these drusy cements would have been influenced by overlying lithologies and lake and soil waters.

The data from the Hard Cap show more negative values for both $\delta^{13} \mathrm{C}$ and $\delta^{18} \mathrm{O}$ than in the Skull Cap and these suggest a slight freshening stratigraphically up-section into the Hard Cap and overlying Great Dirt Bed. Talbot (1990) stated that the co-variance between carbon and oxygen data is more common in closed lakes than in open lakes. He proposed that closed lakes typically show greater regression coefficients $(r)$, above 0.8 , than open lakes. In this study, the regression coefficients are about 0.11 for the Skull Cap and 0.24 for the Hard Cap (Fig. 19), suggesting an open-lake system. Taken together with the fossil evidence (see above) and the petrographic evidence for the absence of both evaporites (indicating hypersalinity) and charophytes (indicating fresh waters) in this FA, these data all indicate brackish-water conditions in an open lacustrine system. Taken together, this evidence argues against West's (1975) and Francis' (1982, 1983, 1984, 1986) hypersaline lagoon, Perry's (1994) freshwater origin and Radley's (2002) closed lake system, and supports Bosence's (1987) previous interpretation of a brackish-water lacustrine system. Moreover, the recognition of microbialite deposits around trees provides detail in support of Bosence's (1987) and Perry's (1994) interpretation of tufa deposits as complex thrombolite mounds as opposed to their earlier interpretations as stromatolites (West 1975; Francis 1982).

The textures and structures of the Microbialite sub-facies on their own are not thought to be diagnostic of specific environments. The combination of all these features indicates that this facies association was deposited along the margins of a shallow brackish-water lake that flooded over shorelines and soils vegetated by conifers.

\section{Hypersaline lacustrine facies association}

The Hypersaline lacustrine FA comprises the Evaporite and the Gypsiferous peloidal packstone facies (Table 2) and is found at Dungy Head, West Lulworth Cove, Fossil Forest, Mupe Bay, Worbarrow Tout, Fishermen's Ledge and Durlston Head (Table 2, Fig. 1). This facies association forms the evaporite collapse breccia of the Broken Beds and adjacent units at the base of the Cypris Freestone (Fig. 3; Table 2). The presence of evaporite crystal pseudomorphs (anhydrite, gypsum and halite) filled with sediment, and reworked gypsum crystals in the Gypsiferous peloidal packstones indicate hypersaline conditions during deposition, as previously interpreted by West (1975). Anderson (1985) and Horne $(1995,2002)$ also interpreted hypersaline conditions on the basis of ostracod assemblages in the Broken Beds. In addition, Radley (2002) inferred palaeosalinities on the basis of mollusc assemblages after compilation of data from Arkell (1941), West (1961), Clements (1973), Barker et al. (1975) and his own work. Although sampled molluscs are not precisely located with respect to the more detailed work presented in this paper, the low mollusc diversity helped Radley (2002) propose that the Broken Beds were deposited in a closed lake system with periodic hypersaline conditions. In view of the underlying (mounded marginal lacustrine) and overlying (bedded marginal lacustrine) facies associations reflecting lacustrine environments, this facies association is interpreted to have been deposited in a hypersaline lacustrine system. 

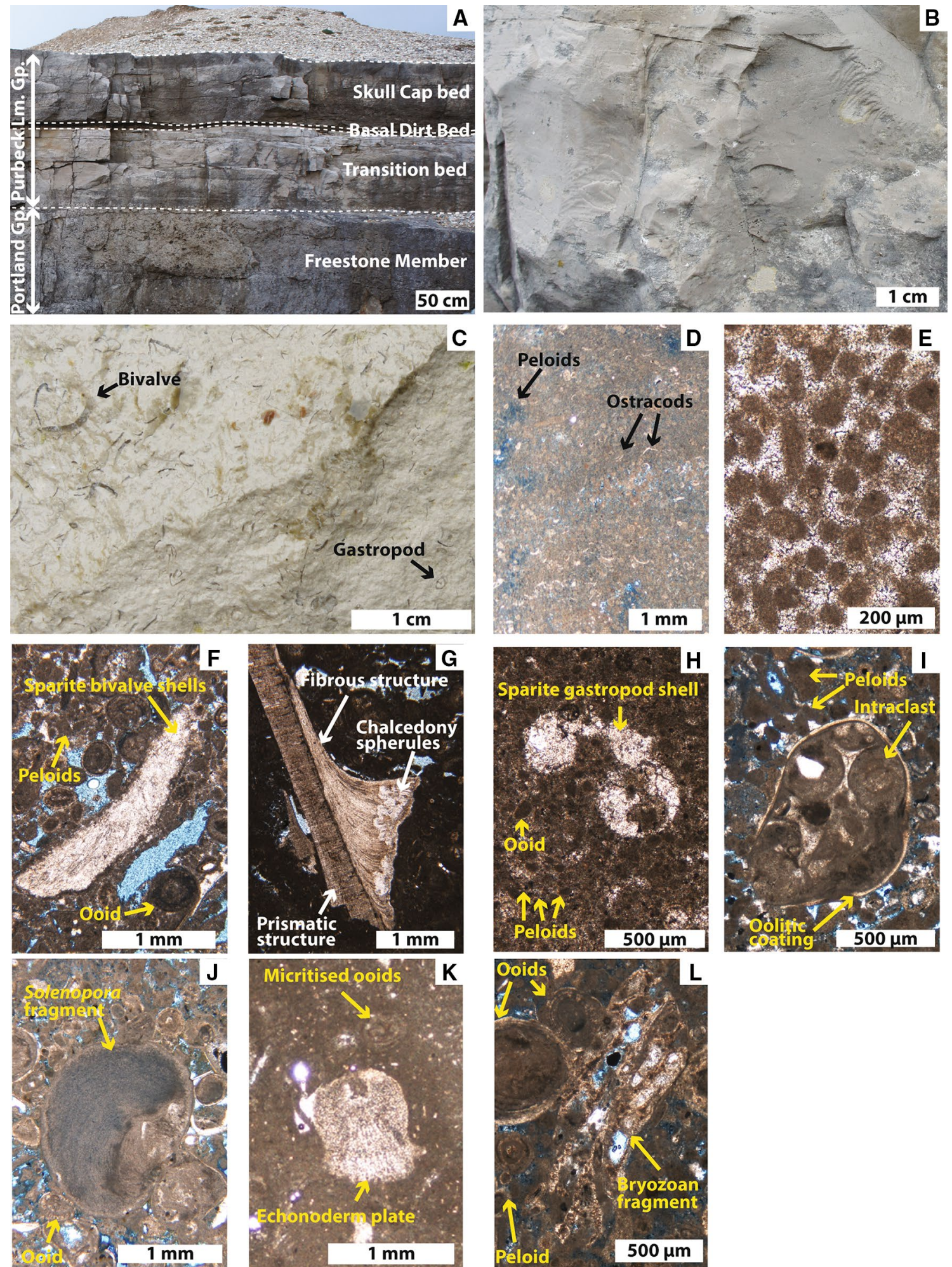

\section{Bedded marginal lacustrine facies association}

The Bedded marginal lacustrine FA is composed of the Cross-bedded peloidal packstone-grainstone and Calcareous sandstone facies (Table 2). This facies association is

unique to the Cypris Freestone and is found at all the locations studied. Its true thickness could only be measured at five locations where the contact with the overlying Hard Cockle Beds is exposed (Tables 1, 2). The coarse-grained facies with sedimentary structures, such as cross-lamination, 
४Fig. 9 Wackestone to fine grainstone facies. a Transition between Portland Group and Purbeck Limestone Group (Portland Bill, Isle of Portland, $50^{\circ} 30^{\prime} 53.20^{\prime \prime} \mathrm{N} ; 2^{\circ} 27^{\prime} 53.20^{\prime \prime} \mathrm{W}$ ). b Close-up view of locally, laminated Wackestone to fine grainstone (God Nore, Isle of Portland, $\left.50^{\circ} 31^{\prime} 31.41^{\prime \prime} \mathrm{N} ; 2^{\circ} 26^{\prime} 22.51^{\prime \prime} \mathrm{W}\right)$. c Close-up view of Wackestone to fine grainstone facies with ostracods and molluscs (Pondfield Cove, $\left.50^{\circ} 36^{\prime} 57.12^{\prime \prime} \mathrm{N} ; 2^{\circ} 11^{\prime} 4.11^{\prime \prime} \mathrm{W}\right)$. d Wackestone with peloids and ostracods (GN2, God Nore, Isle of Portland, 50 $31^{\prime} 31.41^{\prime \prime} \mathrm{N}$; $2^{\circ} 26^{\prime} 22.51^{\prime \prime} \mathrm{W}$ ). e Fine peloidal packstone (PB2, Portland Bill, Isle of Portland, $50^{\circ} 30^{\prime} 53.20^{\prime \prime} \mathrm{N} ; 2^{\circ} 27^{\prime} 31.43^{\prime \prime} \mathrm{W}$ ). f-l Reworked allochems from the underlying Portland Group. f Sparite and fibrous bivalve shell and micritised ooids in a fine peloidal grainstone (BQ1, Broadcroft Quarry, Isle of Portland, 50 $32^{\prime} 53.74^{\prime \prime} \mathrm{N} ; 2^{\circ} 25^{\prime} 35.07^{\prime \prime} \mathrm{W}$ ). g Bivalve shell showing both fibrous and prismatic structures and micritised ooids in a peloidal packstone (PB1, Portland Bill, Isle of Portland, 50 $30^{\prime} 53.20^{\prime \prime} \mathrm{N} ; 2^{\circ} 27^{\prime} 31.43^{\prime \prime} \mathrm{W}$ ). h Gastropod shell replaced and filled by spar cement, peloids and superficial ooids in a fine peloidal grainstone (PB3, Portland Bill, Isle of Portland, $50^{\circ} 30^{\prime} 53.20^{\prime \prime} \mathrm{N}$; $\left.2^{\circ} 27^{\prime} 31.43^{\prime \prime} \mathrm{W}\right)$. i Intraclast of oolitic grainstone with a cortical coating and peloids in a fine peloidal grainstone (GN3, God Nore, Isle of Portland, $\left.50^{\circ} 31^{\prime} 31.41^{\prime \prime} \mathrm{N} ; 2^{\circ} 26^{\prime} 22.51^{\prime \prime} \mathrm{W}\right)$. j Solenopora fragment and ooids in a fine peloidal grainstone (GN3, God Nore, Isle of Portland, $50^{\circ} 31^{\prime} 31.41^{\prime \prime} \mathrm{N} ; 2^{\circ} 26^{\prime} 22.51^{\prime \prime} \mathrm{W}$ ). k Echinoderm plate (with straight extinction in XPL), micritised ooids and ostracod shell fragments (PB1, Portland Bill, Isle of Portland, 50 30'53.20"N; 2 $27^{\prime} 31.43^{\prime \prime} \mathrm{W}$ ). 1 Bryozoan fragment, foraminifers, peloids and mixed and micritised ooids in a fine peloidal grainstone (GN3, God Nore, Isle of Portland, $50^{\circ} 31^{\prime} 31.41^{\prime \prime} \mathrm{N} ; 2^{\circ} 26^{\prime} 22.51^{\prime \prime} \mathrm{W}$ )

cross-stratification and herring-bone cross-stratification indicates a high-energy shallow marginal environment.

Herring-bone cross-stratification is known to occur in lakes with a water body large enough to be influenced by gravitational forces (the moon and the sun) as in Lake Superior (about $82,103 \mathrm{~km}^{2}$ ) or Lake Michigan (about $58,000 \mathrm{~km}^{2}$ ) in the North American Great Lakes (Mortimer and Fee 1976; Kennish 1986; Mann and Lazier 1991; Mortimer 2004; Trebitz 2006). Alternatively, they can be generated by opposing wind-driven currents as documented by Rusnak (1960)for a hypersaline lake Laguna Merida (about $1230 \mathrm{~km}^{2}$ ) in Texas (USA) and by Ainsworth et al. (2012) in Lake Eyre $\left(9500 \mathrm{~km}^{2}\right)$ in Australia. They can also be the results of seiche events where two waves of opposite direction are combined to create a unique and larger wave (Sager et al. 1985; Mortimer 2004). With the Wessex Basin being about $45,000 \mathrm{~km}^{2}$ (Fig. 1), tides or seiche events would be expected to create such herring-bone stratification. However, the Portland-Wight sub-basin is much smaller (Fig. 1), about $12,000 \mathrm{~km}^{2}$, which is a similar area to Lake Eyre (see above) where wind-driven currents may have controlled the formation of herring-bone cross-stratification.

The smooth-shelled ostracods Fabanella boloniensis, Mantelliana purbeckensis, and Mantelliana cyrton were identified at the base of the Cypris Freestone at God Nore, Isle of Portland, and reflect a saline lacustrine environment (Ray Bate, pers. comm., June 2017). Previous records of non-marine biotas such as hypersaline tolerant S-phase ostracods (Anderson 1985; Horne 2002) and brackish to hypersaline tolerant gastropods indicate a closed lake system (Clements 1973). This is confirmed by the occurrence of sediment-filled, halite pseudomorphs indicating hypersaline conditions (cf. West 1975). Altogether, these features suggest a marginal, shallow hypersaline lacustrine environment.

\section{Facies models for the Mupe Member}

The incorporation of these five facies associations into the ideal sequences for facies transition (Fig. 20) is used, together with modern-day analogues, as a basis for the establishment of two facies models for the Mupe Member. The Sub-littoral lacustrine FA, found at the base of the succession, is overlain by the Emergent FA and the ideal sequences (Fig. 20) show that the latter is closely related to the Mounded marginal lacustrine FA as it is mainly found in between palaeosoils. The Emergent FA is most likely to be overlain by the Bedded marginal lacustrine FA as indicated in Fig. 20. These facies associations are interpreted to have formed in a through-flowing brackish-water lake. The Hypersaline lacustrine FA is interbedded with the Bedded marginal lacustrine FA (Fig. 20). This facies relationship enables the identification of two main depositional environments: a brackish-water phase in the lower part of the Mupe Member and a hypersaline water phase in the upper part. The transition between environments is marked by a sharp surface and a random change in facies (as discussed earlier) where the Great Dirt Bed (Conglomerate facies) and the Soft Cap (Microbialite and Intraclastic peloidal packstone-grainstone facies) can be in contact with either the Cypris Freestone (Cross-bedded peloidal packstone-grainstone facies) or with the Broken Beds (Evaporite facies). This was observed at 15 locations; 13 where microbial mounds and inter-mound facies of the Soft Cap are overlain by the Evaporite facies (seven locations) and the Cross-bedded peloidal packstone-grainstone (six locations), against only two locations where the Conglomerate facies of the Great Dirt Bed is overlain by the Cross-bedded peloidal packstone-grainstone facies of the Cypris Freestone. This shows the importance of integrating petrographic and outcrop studies together with facies transition analysis to strengthen the validity of facies relationship diagrams.

\section{Brackish-water phase}

The lower part of the Mupe Member is interpreted to have formed in a brackish-water, open-lake system of Talbot and Allen (1996) or a balanced-fill lake of Bohacs et al. (2000), based on the facies, biotas and stable isotope analyses. Figure 21 illustrates the proposed depositional setting of a shallow margin of this lake system based on the integration of 

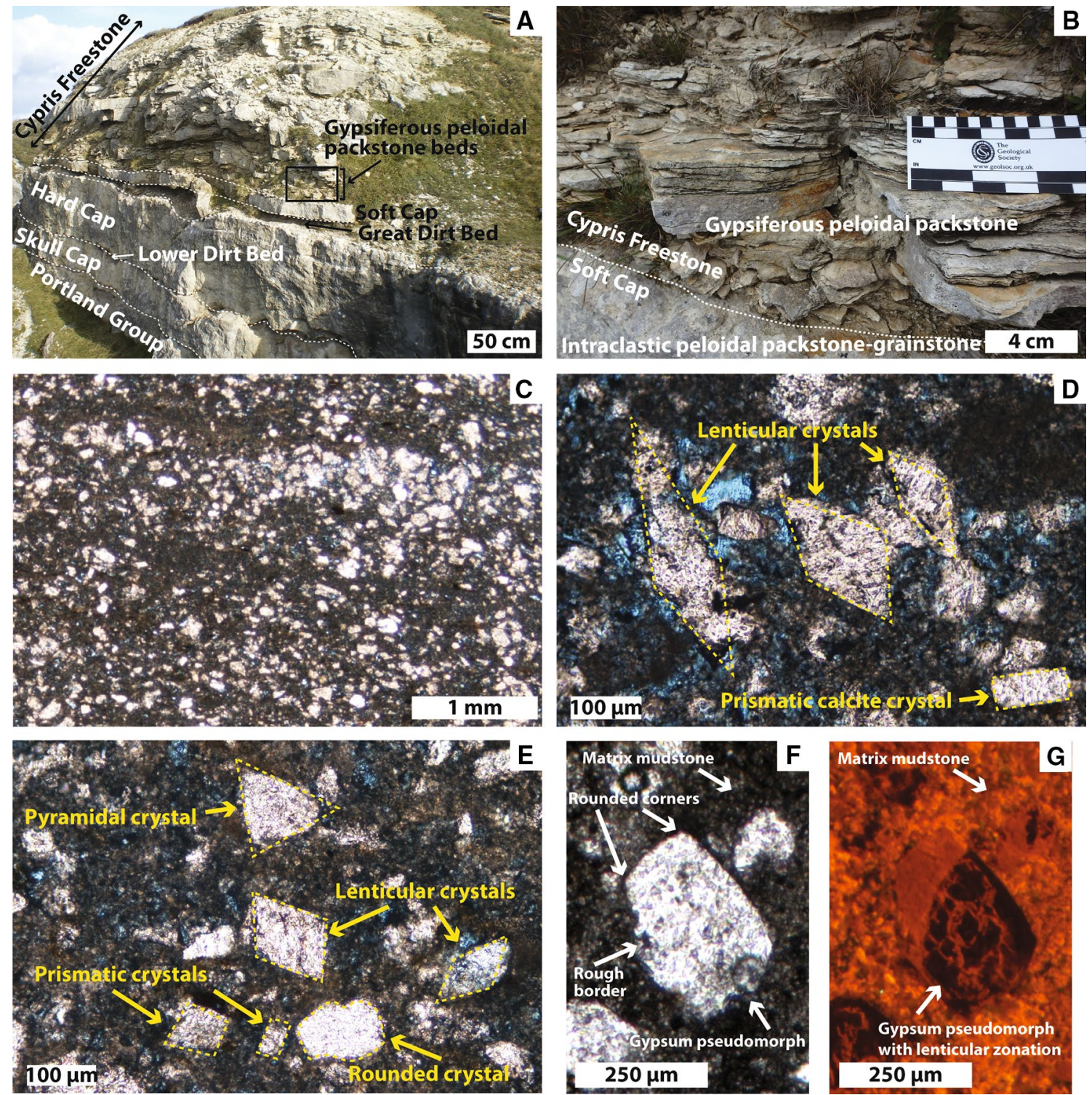

Fig. 10 Gypsiferous peloidal packstone facies. a Location of the laminated beds just above the Soft Cap bed and at the base of the Cypris Freestone unit. The black box locates b and $\mathbf{c}$ (South West Bowers Quarry, Isle of Portland, 50 $\left.32^{\prime} 40.06^{\prime \prime} \mathrm{N} ; 2^{\circ} 27^{\prime} 10.56^{\prime \prime} \mathrm{W}\right)$. b Laminated packstone beds overlying Soft Cap grainstone (South West Bowers Quarry, Isle of Portland, 50 $\left.32^{\prime} 40.06^{\prime \prime} \mathrm{N} ; 2^{\circ} 27^{\prime} 10.56^{\prime \prime} \mathrm{W}\right)$. c Prismatic calcite crystals after gypsum within a micrite matrix (CQ10, Coombefield Quarry, Isle of Portland, $50^{\circ} 31^{\prime} 58.25^{\prime \prime} \mathrm{N}$; $\left.2^{\circ} 26^{\prime} 33.65^{\prime \prime} \mathrm{W}\right)$. d Details of lenticular and prismatic gypsum pseu-

work presented in this paper together with facies from a modern analogue, the freshwater lake of Laguna Bacalar, Yucatan Peninsula, Mexico (Gischler et al. 2008, 2011; and observations by the authors in 2014-2015).

Laguna Bacalar lake is about $50 \mathrm{~km}$ long, 1-2 km wide, and up to $20 \mathrm{~m}$ deep, set in a humid tropical climate (Pérez et al. 2011) in the equatorial zone (Gischler et al. 2008, 2011), with thrombolite mounds along its shores (Fig. 22). domorphs (highlighted with yellow dashed lines) within a mudstone matrix (TQ11, Tout Quarry, Isle of Portland, 50 $33^{\prime} 11.57^{\prime \prime} \mathrm{N}$; $\left.2^{\circ} 26^{\prime} 36.83^{\prime \prime} \mathrm{W}\right)$. e Prismatic, lenticular and rounded gypsum pseudomorphs (highlighted with yellow dashed lines) in PPL (SWB7, South West Bowers, Isle of Portland, $\left.50^{\circ} 32^{\prime} 40.06^{\prime \prime} \mathrm{N} ; 2^{\circ} 27^{\prime} 10.56^{\prime \prime} \mathrm{W}\right)$. f, g PPL and CL views of lenticular calcite crystal showing a lenticular dark zone in the centre of the pseudomorph under CL (CQ10, Coombefield Quarry, Isle of Portland, 50³1'58.25"N; $2^{\circ} 26^{\prime} 33.65^{\prime \prime} \mathrm{W}$ )

The freshwater is supplied by groundwater from a limestone hinterland through cenotes (Gischler et al. 2008, 2011) and flows towards the north. This differs from the situation that is interpreted for the Purbeck lake. Here, fluvial run-off from the carbonate hinterland in the northern footwall region is considered to be the likely source area and surface waters would have been channelled through the relay ramp in the centre of the study area into the 

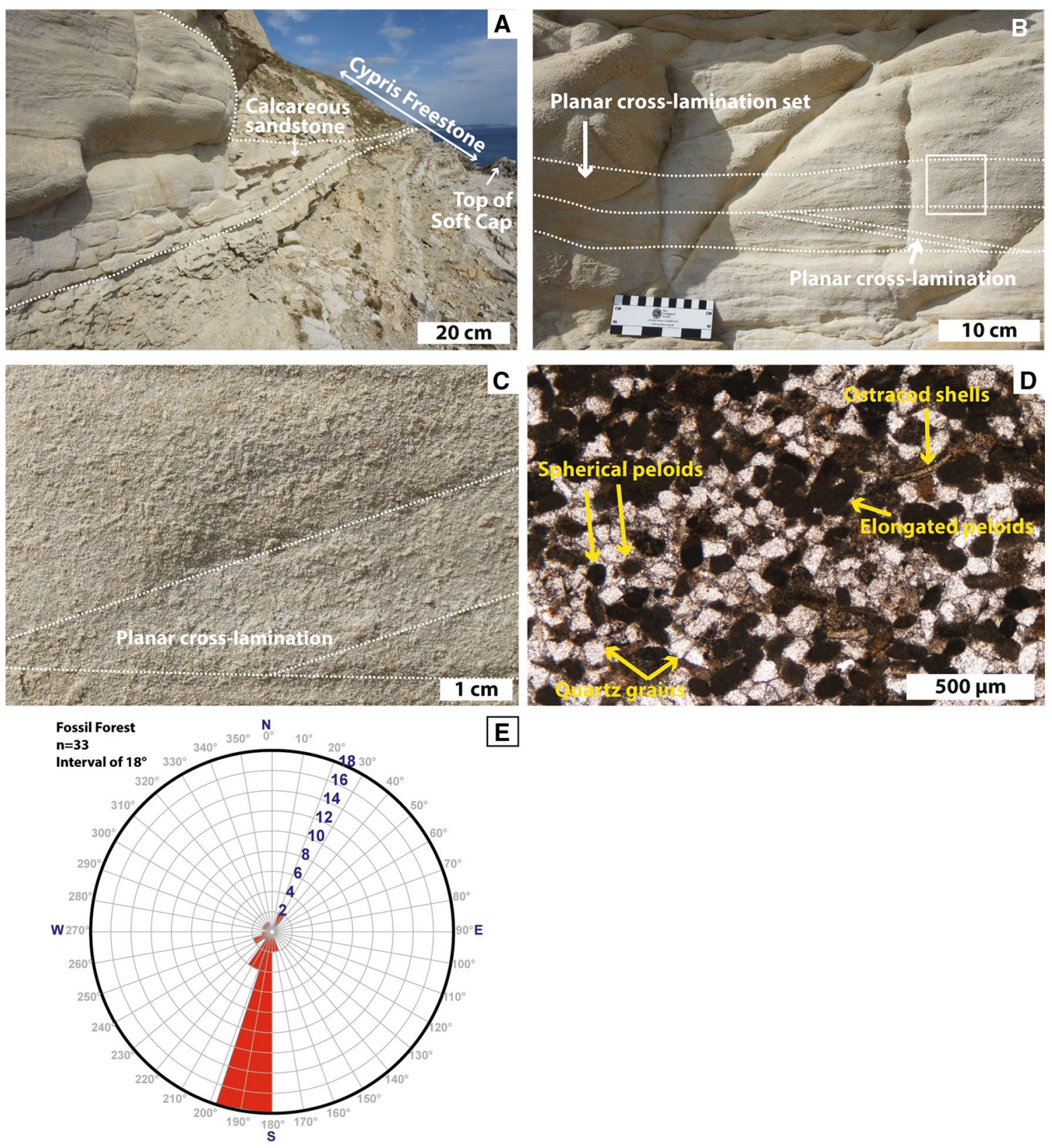

E

Fig. 11 Calcareous sandstone facies. a Location of Calcareous sandstone within Cypris Freestone unit (Fossil Forest, 50³6'58.37"N; $\left.2^{\circ} 14^{\prime} 23.09^{\prime \prime} \mathrm{W}\right)$. b Herring-bone cross-stratification. The white square locates c (Fossil Forest, 50 $36^{\prime} 58.37^{\prime \prime} \mathrm{N} ; 2^{\circ} 14^{\prime} 23.09^{\prime \prime} \mathrm{W}$ ). c Calcareous sandstone facies in detail with abundant quartz grains weathering out on surface (Fossil Forest, 50³6'58.37"N; 2¹4'23.09"W). d Quartz

Purbeck lake (Fig. 1). However, the carbonate facies and microbial mound sizes, morphologies and internal microstructures in Laguna Bacalar are similar to those in the lower part of the Mupe Member. In particular, the thrombolite mounds found associated with shoreline trees in the shallow lake margins are similarly associated with peloidal grainstone facies with ostracods and molluscs. The internal microstructure of the thrombolites is similar to

grains, elongated and spherical peloids, ostracod valve with calcite cement (WLC9, West Lulworh Cove, 50 37'1.27"N; $2^{\circ} 14^{\prime} 55.18^{\prime \prime} \mathrm{W}$ ). e Orientation and direction measurements of the cross-lamination at Fossil Forest with 33 measurements showing a main direction at $\mathrm{N} 190\left(50^{\circ} 36^{\prime} 58.37^{\prime \prime} \mathrm{N} ; 2^{\circ} 14^{\prime} 23.09^{\prime \prime} \mathrm{W}\right)$

that of the Purbeck microbialites, as both have constructed upward-radiating filament moulds incorporating the surrounding sediments and fossils. The modern thrombolites exhibit several sizes and morphologies, microbial mats, small tabular mounds in shallow areas, flat-topped ledges and large mounds (up to $2 \mathrm{~m}$ high, Fig. 22) in intermediate depth areas, and microbial mats in deeper areas $(>2 \mathrm{~m})$. The mounds develop along the shores and grow towards 

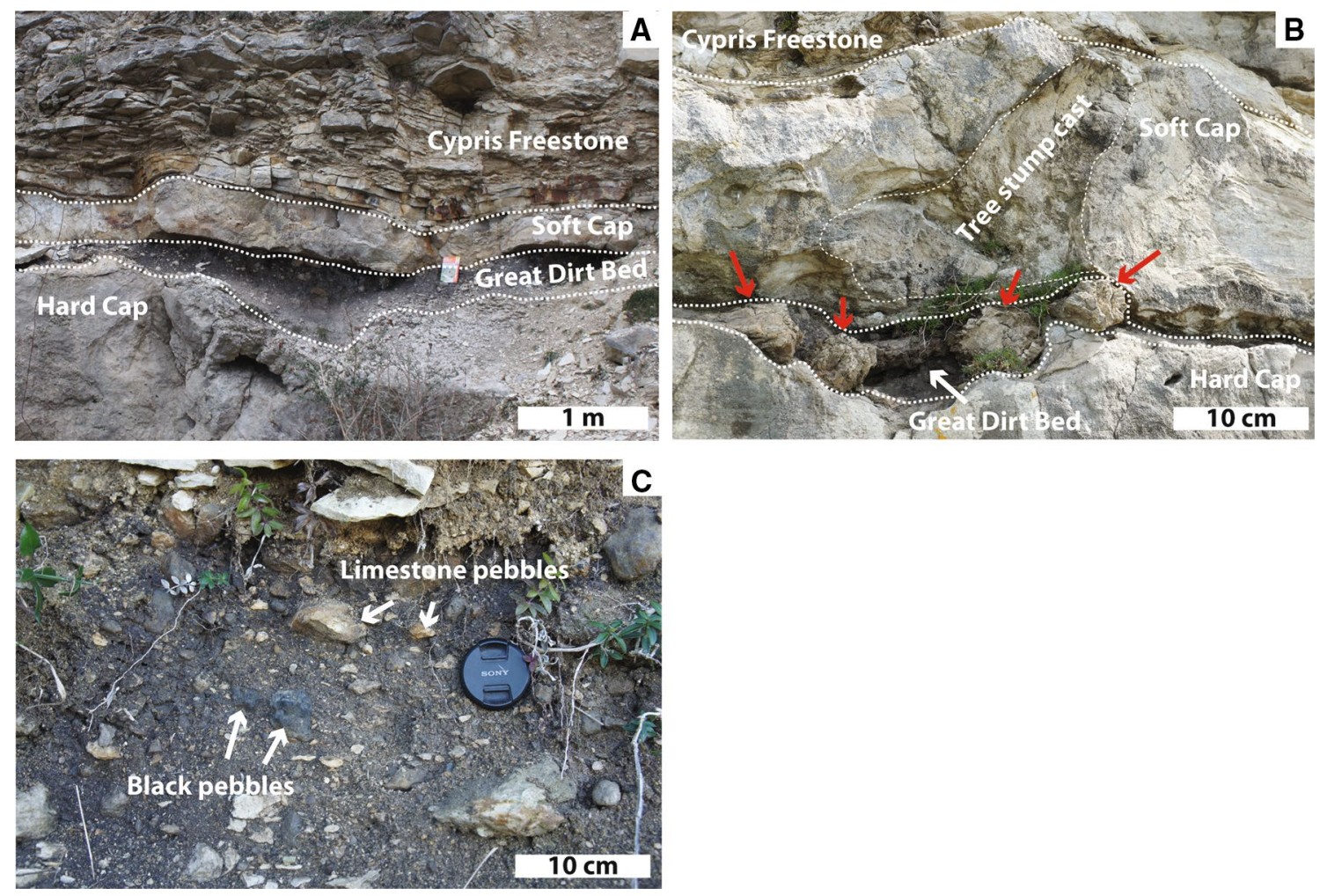

Fig. 12 Conglomerate facies. a Location of the Great Dirt Bed with Conglomerate facies (Penn's Weare, Isle of Portland, 50 $32^{\prime} 27.46^{\prime \prime} \mathrm{N}$; $2^{\circ} 25^{\prime} 35.31^{\prime \prime} \mathrm{W}$ ). b Silicified tree stump and roots (red arrows) within the Great Dirt Bed and stump cast in the Soft Cap (West Cliff, Isle of
Portland, $\left.50^{\circ} 32^{\prime} 2.75^{\prime \prime} \mathrm{N} ; 2^{\circ} 27^{\prime} 14.87^{\prime \prime} \mathrm{W}\right)$. c Conglomerate facies with black and white limestone pebbles (South West Bowers, Isle of Portland, $50^{\circ} 32^{\prime} 40.06^{\prime \prime} \mathrm{N} ; 2^{\circ} 27^{\prime} 10.56^{\prime \prime} \mathrm{W}$ )

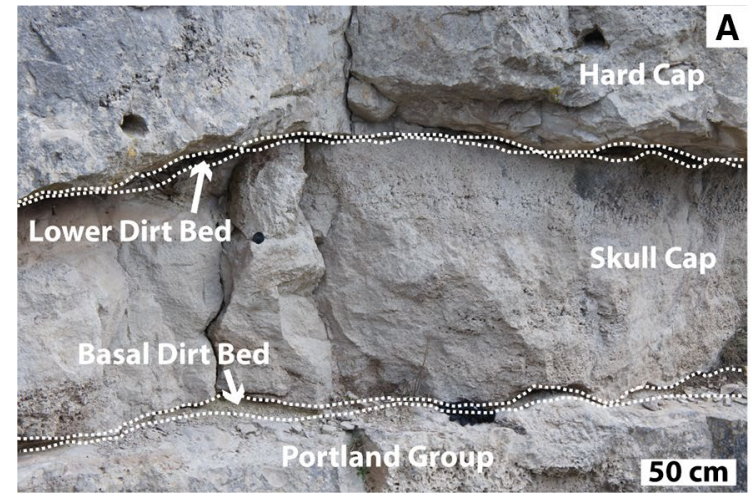

Fig. 13 Carbonaceous marl facies. a Location of the Lower Dirt Bed and Basal Dirt Bed comprising the Carbonaceous marl facies (Tout Quarry, Isle of Portland, 50³3'11.57"N; $2^{\circ} 26^{\prime} 36.83^{\prime \prime W}$ ). b Close-up

the lake basin and are commonly found growing around roots of mangrove trees. The microbialites show very rapid growth rates of up to $1 \mathrm{~cm} /$ year as measured during a March 2015 field survey. This rate was measured on stakes in an abandoned harbour built around 25 years ago, where thrombolites have developed a thickness up to $25 \mathrm{~cm}$. In

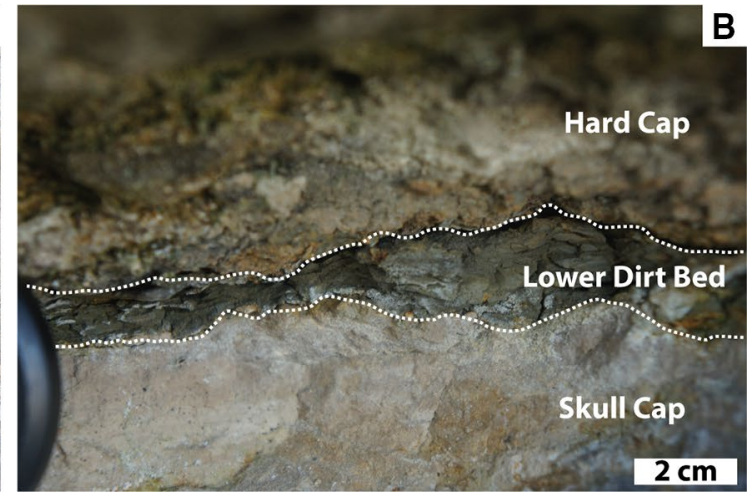

view of the Lower Dirt Bed, black and brown lamination can be seen in a dark, organic-rich marl (South West Bowers, Isle of Portland, $50^{\circ} 32^{\prime} 40.06^{\prime \prime} \mathrm{N} ; 2^{\circ} 27^{\prime} 10.56^{\prime \prime} \mathrm{W}$ )

the deepest part of the lake (2-20 m), fine-grained peloidal carbonates are deposited (Gischler et al. 2008, 2011).

The lower part of the Mupe Member comprises three stratigraphic units (the Skull, Hard and Soft Caps) of the Sub-littoral lacustrine and Mounded marginal lacustrine FA deposited between three palaeosoils (Emergent FA). They therefore represent three depositional sequences. The 

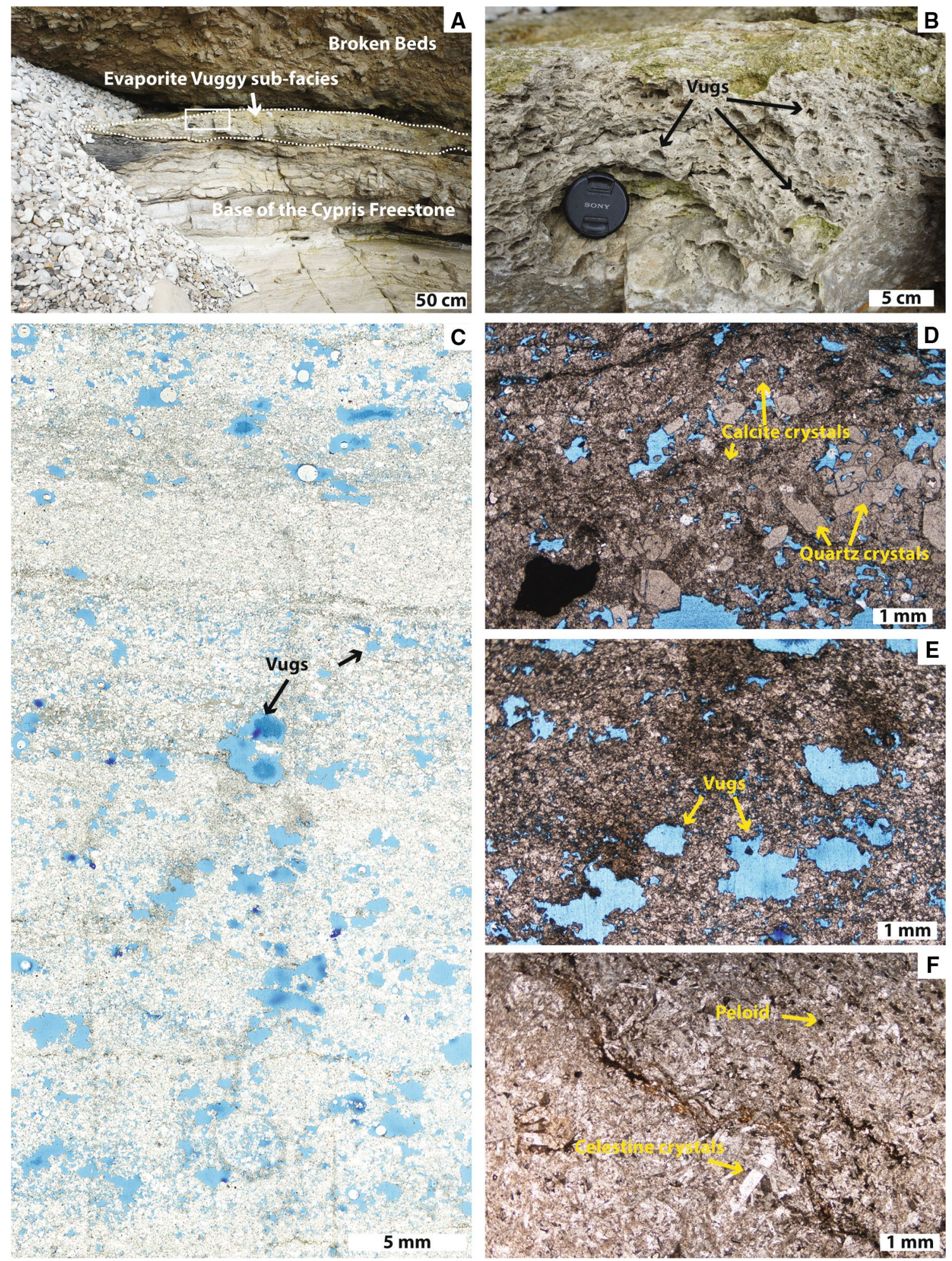

Fig. 14 Evaporite vuggy sub-facies. a Evaporitic beds below the Broken Beds. The white box locates b (Worbarrow Tout, $50^{\circ} 36^{\prime} 55.95^{\prime \prime} \mathrm{N}$; $\left.2^{\circ} 11^{\prime} 11.70^{\prime \prime} \mathrm{W}\right)$. b Close-up view of a, note the vugs up to $1 \mathrm{~cm}$ in diameter (Worbarrow Tout, 50 $36^{\prime} 55.95^{\prime \prime} \mathrm{N} ; 2^{\circ} 11^{\prime} 11.70^{\prime \prime} \mathrm{W}$ ). c Thinsection scan with 1-2-mm-sized vugs in a calcite crystalline texture (MB11, Mupe Bay, 50 $36^{\prime} 58.37^{\prime \prime} \mathrm{N} ; 2^{\circ} 13^{\prime} 42.20^{\prime \prime} \mathrm{W}$ ). d Quartz crystals

(between $500 \mu \mathrm{m}$ and $1 \mathrm{~mm}$ ) and calcite crystals replacing original lithology (WT8, Worbarrow Tout, 50³6'55.95"N; $2^{\circ} 11^{\prime} 11.70^{\prime \prime} \mathrm{W}$ ). e Millimetre-sized vugs in a calcite mosaic, note squared edges to vugs indicating replacement of former evaporite minerals by calcite (MB11, Mupe Bay, 50 36'58.37"N $2^{\circ} 13^{\prime} 42.20^{\prime \prime} \mathrm{W}$ ). f Celestine crystals and peloids (DH1, Durlston Head, 50 35'43.58"N; $1^{\circ} 57^{\prime} 3.73^{\prime \prime} \mathrm{W}$ ) 

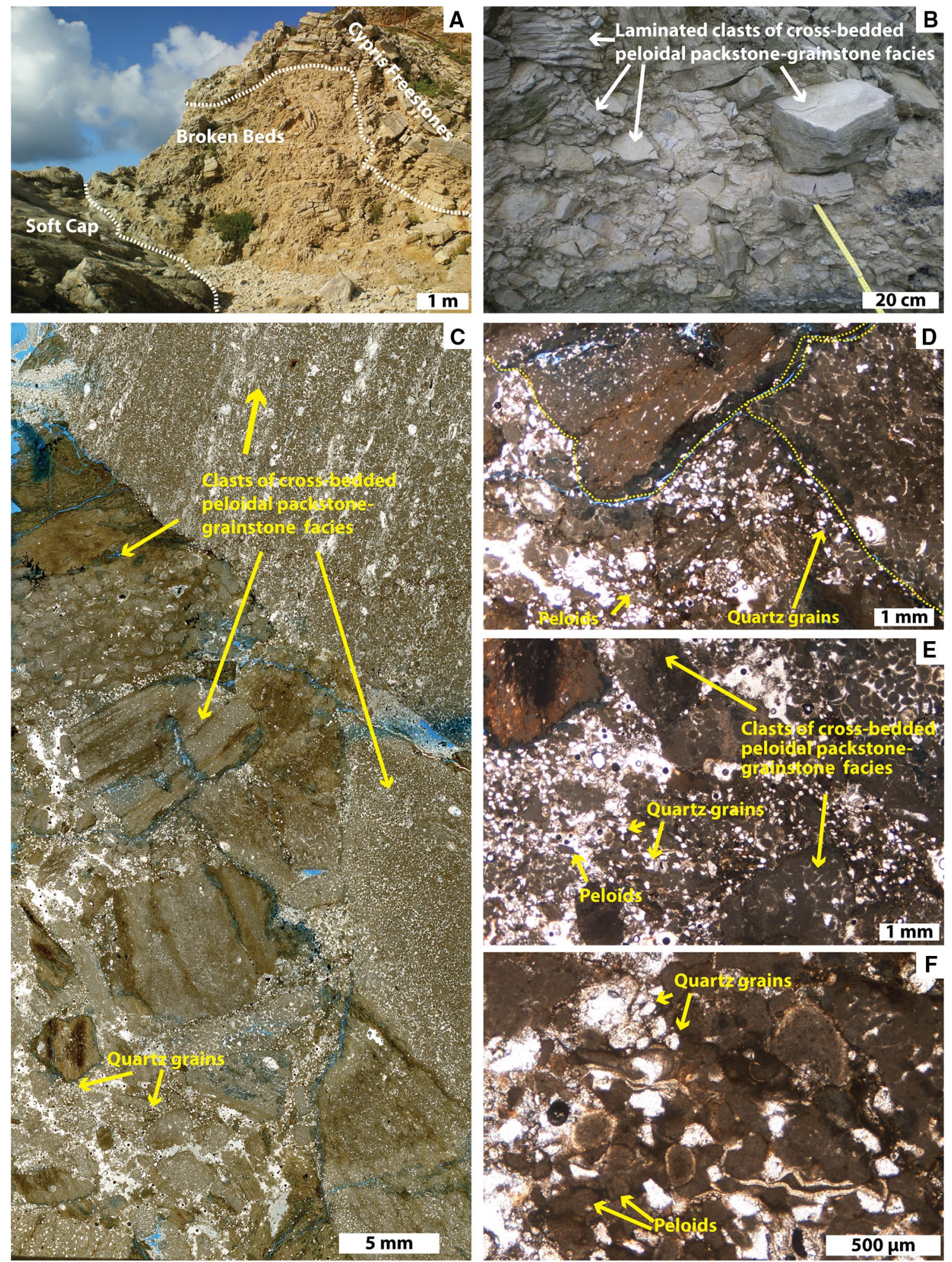

Fig. 15 Evaporite breccia sub-facies. a Field view of the Broken Beds unit made of the brecciated sub-facies (Fossil Forest, 50 $36^{\prime} 58.37^{\prime \prime} \mathrm{N}$; $\left.2^{\circ} 14^{\prime} 23.09^{\prime \prime} \mathrm{W}\right)$. b Close-up view of the Broken Beds made of cobble to boulder-sized blocks (West side of Lulworth Cove, $50^{\circ} 37^{\prime} 1.27^{\prime \prime} \mathrm{N}$; $\left.2^{\circ} 14^{\prime} 55.18^{\prime \prime} \mathrm{W}\right)$. c Thin-section scan showing relatively large clasts of Cross-bedded peloidal packstone-grainstone facies (WLC7, West Lulworth Cove, $\left.50^{\circ} 37^{\prime} 1.27^{\prime \prime} \mathrm{N} ; 2^{\circ} 14^{\prime} 55.18^{\prime \prime} \mathrm{W}\right)$. d Close-up view of $\mathbf{a}$, the matrix is composed of quartz grains, peloids and ostracods (WLC7, West Lulworth Cove, 50 $37^{\prime} 1.27^{\prime \prime} \mathrm{N} ; 2^{\circ} 14^{\prime} 55.18^{\prime \prime} \mathrm{W}$ ). e Close-up view of $\mathbf{a}$, smaller angular intraclasts can be identified within a matrix made of quartz grains, peloids and ostracods. f Closeup view of $\mathbf{c}$ detailing the matrix of the sub-facies (WLC7, West Lulworth Cove, $50^{\circ} 37^{\prime} 1.27^{\prime \prime} \mathrm{N} ; 2^{\circ} 14^{\prime} 55.18^{\prime \prime} \mathrm{W}$ ) 


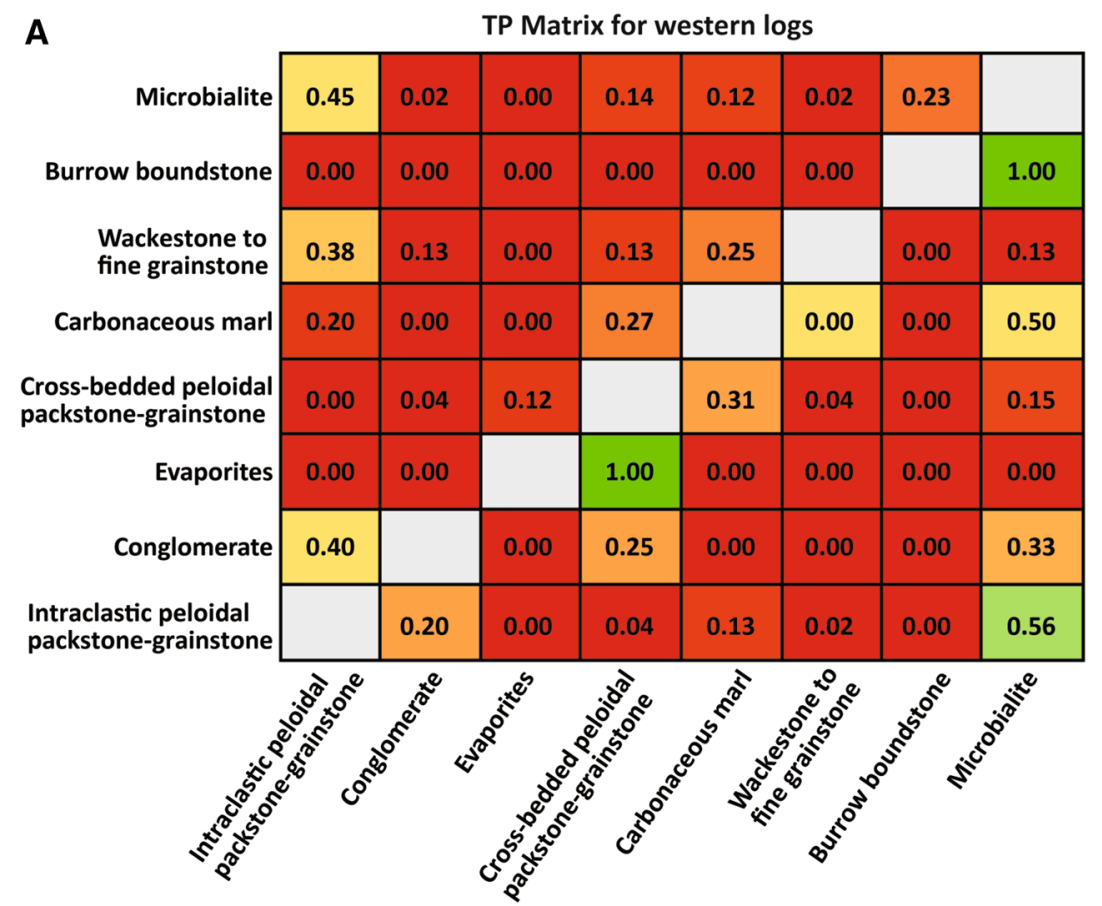

Ideal sequence for western logs

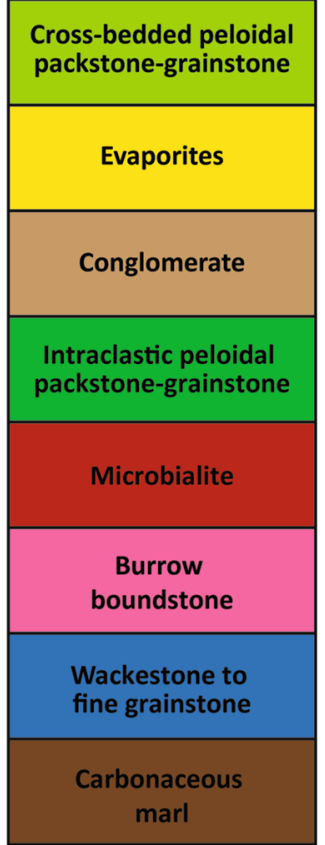

B

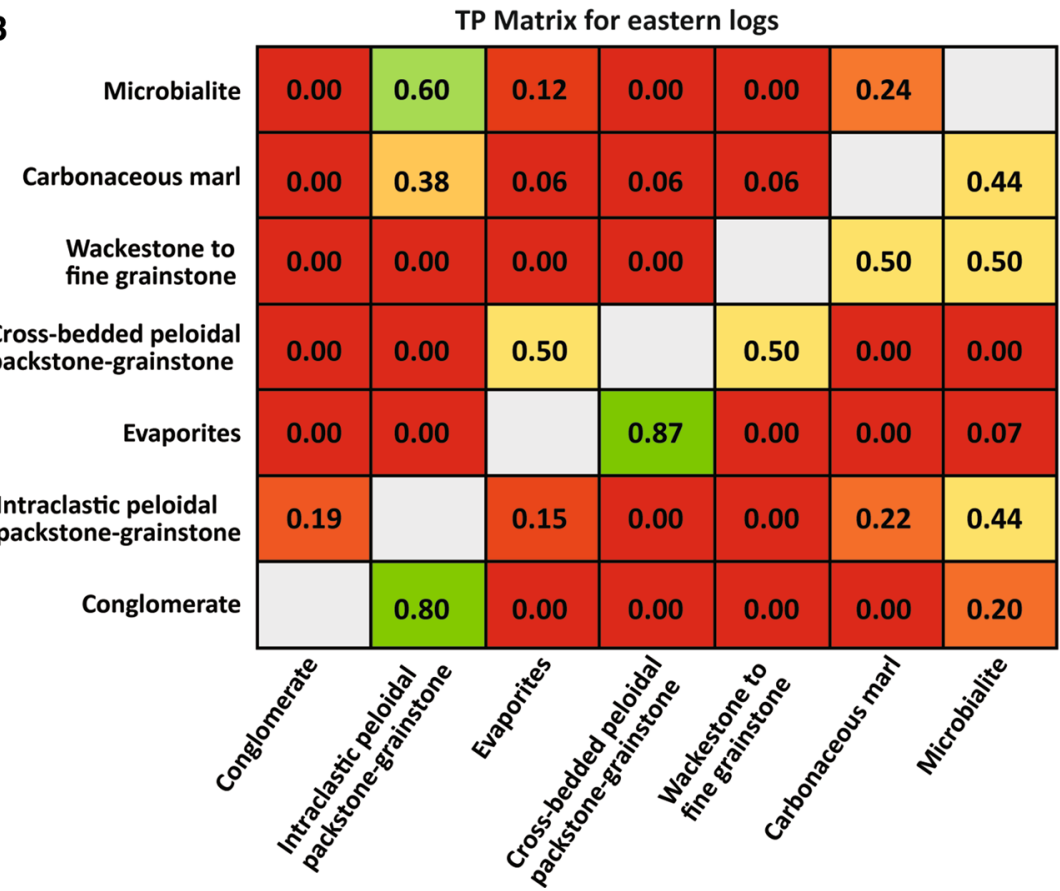

Ideal sequence for eastern logs

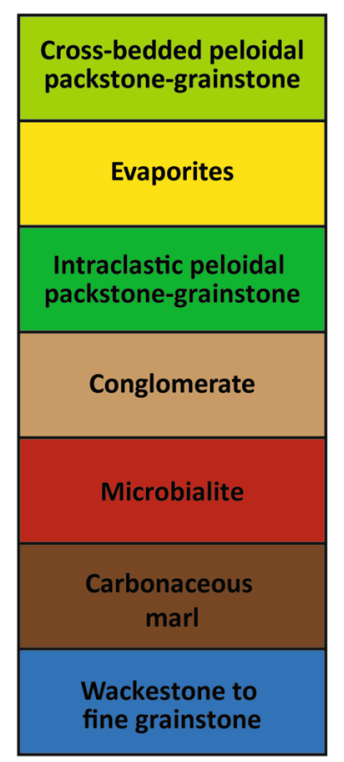

Fig. 16 Optimised transition probability matrices and optimised successions (Burgess 2016) for the Mupe Member in south Dorset from the western area (a) and eastern area (b). Transitions are not equiprobable, suggesting preferred occurrence of certain facies vertically and therefore laterally adjacent during deposition, assuming

palaeosoils were deposited after a drop in lake level as indicated by erosion of underlying deposits of either the Portland Group (for the Basal Dirt Bed) or the Transition Bed, the Skull Cap and the Hard Cap beds (Fig. 20). On the emergent little or no missing time. The vertical successions. Note that to simplify analysis, some facies have been grouped, so the Microbialite facies combines the Thrombolite and Stromatolite sub-facies; and the Evaporites facies combines the Evaporite vuggy sub-facies and the Gypsiferous peloidal packstone facies

lake margins, the palaeosoils supported a vegetation of ancient cypress trees and cycadophytes. In the littoral zone and shallowest parts of the lake, small, tabular microbial mounds developed either around tree stumps, or associated 

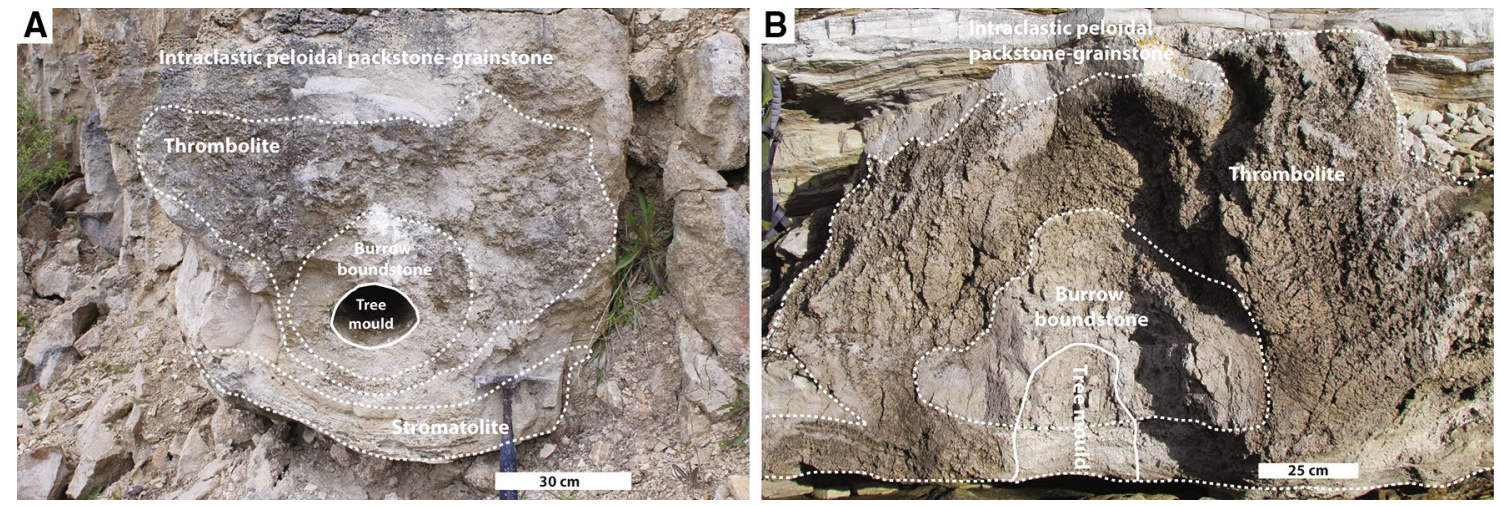

Fig. 17 Microbial mounds at outcrop. a Developed around a fallen tree (Hard Cap, Broadcroft Quarry, Isle of Portland). b Developed around an in situ tree stump (Soft Cap, Fossil Forest, picture courtesy of Estanislao Kozlowski)

with trees, and surrounded by inter-mound coarse-grained facies (Intraclastic peloidal packstone-grainstone), comparable to those seen in Laguna Bacalar. Where the accommodation space was greater in slightly deeper waters the mounds are higher, more irregularly shaped, thicker and developed around inundated tree trunks and branches (as with the large mounds found in intermediate depths in Laguna Bacalar). These are surrounded by an inter-mound, coarse-grained facies with mound-derived intraclasts, as is also the case in Laguna Bacalar. Deeper into the Purbeck lake, in the sub-littoral zone, microbial activity formed mats alternating with horizons of coarse-grained facies (Intraclastic peloidal packstone-grainstone facies) as represented by the microbial mats found in the deepest part of the margins in Laguna Bacalar. The reason these deeper-water mats did not develop into tabular or complex mounds could be due to one factor or a combination of several factors. A lack of light would reduce or stop the photosynthesis that would decrease microbial growth rate; a lack of sediment or of dissolved carbonate due to a change in water chemistry would reduce the trapping and binding process and the microbialites would not be preserved, and/or an excess of sediment may result in the microbial mats being smothered (Dupraz et al. 2009). As suggested by comparison with Laguna Bacalar (see above) and general lacustrine facies models (Platt and Wright 1991; Bohacs et al. 2000), the Purbeck brackish-water lake of this study most likely had low relief, ramp-type margins, with microbial mounds confined to the littoral zone.

In the deepest part of the lake, the deposition of the finegrained facies of the Sub-littoral lacustrine FA occurred with no microbial build-ups. Although a lateral transition between the Transition Bed and the Skull, Hard or Soft Caps was never observed in outcrops, the abundance of peloids and microbial intraclasts in the Wackestone to fine grainstone facies of the Transition Bed indicates deposition in adjacent deeper-water settings (see above). As a consequence, the depositional environment of Sub-littoral lacustrine FA can only be inferred.

The depositional environments of the Caps and Dirt Beds have been debated since the 19th century when Webster (1826), Buckland and De La Bèche (1835) and Arkell (1947) proposed a freshwater environment because of the trees and their interpretation of the surrounding tufa or "burr" deposits. Later, West (1975) proposed a lagoonal environment with hypersaline waters with algal limestones based on inferred palaeosalinities from biotas and comparison with developments of stromatolites from the hypersaline Arabian Gulf sabkhas. This interpretation had been proposed earlier by Brown $(1963,1964)$ who worked on the algal limestones and was later supported by Francis' $(1982,1983,1984,1986)$ work on the Dirt Beds (i.e. the palaeosoils). Brown $(1963,1964)$ detailed the types of algae associated with the algal deposits to belong to Ortonella and Girvanella based on preserved filament morphologies and Solenopora, and inferred deposition to have occurred in a hypersaline environment. However, this has since been shown to be erroneous, as the first two taxa are now interpreted as sheaths of filamentous cyanobacteria (Riding 1991) that form in a wide range of environments and the Solenopora is interpreted to be derived from the underlying Portland Limestone (see above). Francis $(1982,1983,1984,1986)$ demonstrated that the palaeosoils were rendzina profiles at different stages of maturity that supported conifer and cycadophyte forests that developed under a semi-arid Mediterranean-type climate. According to Francis (1982), the hypersalinity of the waters is consistent with this type of climate and with the rapid death and preservation of trees when drowned. It was only with Bosence's (1987) work on facies of the Cap and Dirt Beds and Perry's (1994) work on the tufa deposits that the freshwater origin was reconsidered. Bosence (1987) demonstrated that stromatolites are a minor component of the "algal limestones" of previous workers and that 


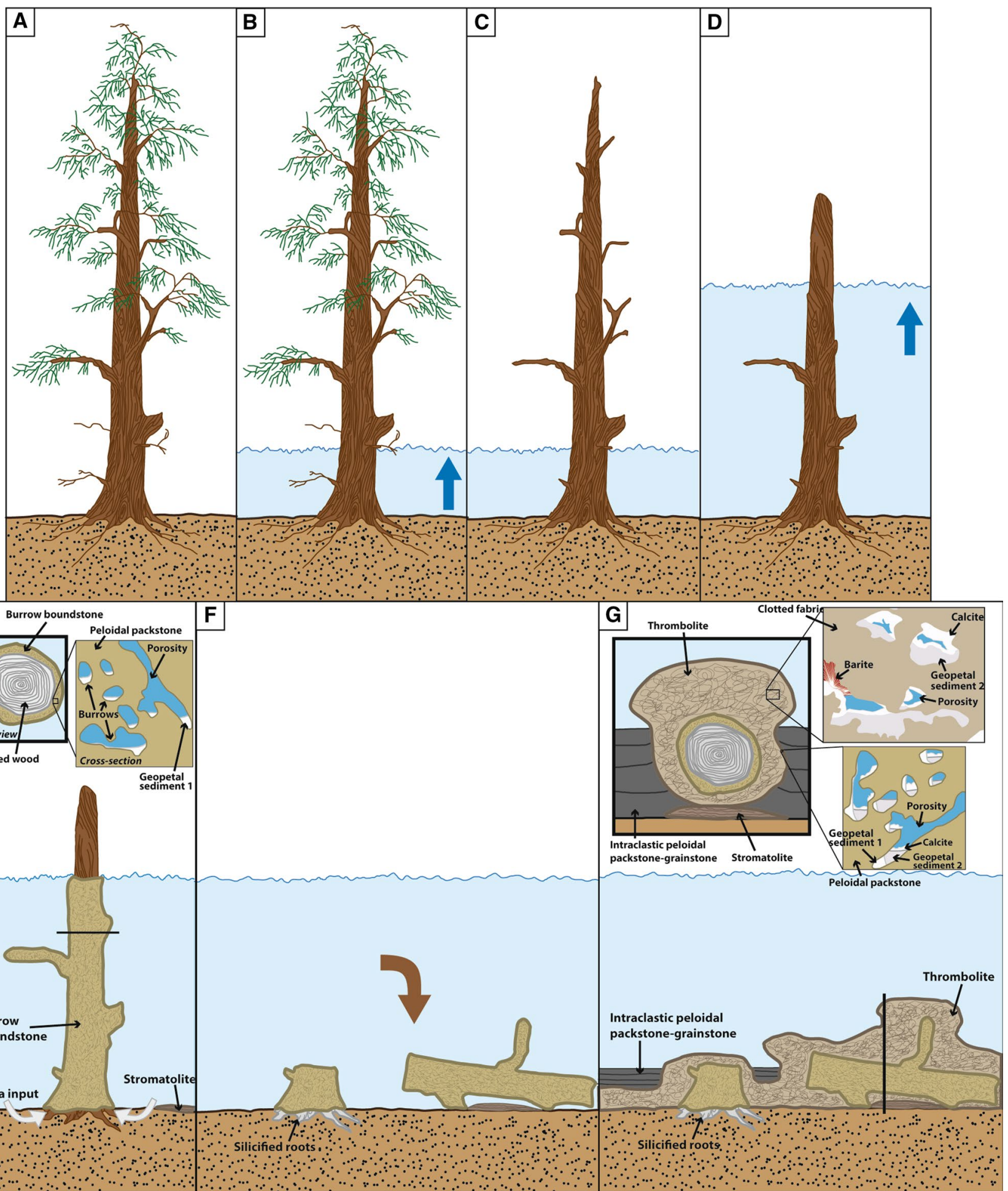

Fig. 18 Reconstruction of events leading to the formation of the microbial mounds. a Protocupressinoxylon purbeckensis tree growing in Purbeck soil (after Francis 1982). b Flooding of vegetated soil with brackish-water lake. c Decay of the trees. d Lake level continues to rise to at least 4-m depth, which is accompanied by tree decay. e Accumulation of the Burrow boundstone facies and Stromatolite sub-facies. The black line locates the upper cross section. See text for discussion on silica source. $\mathbf{f}$ The tree breaks with the Burrow boundstone casing and falls near its stump. $\mathrm{g}$ In situ stump with broken-off tree trunk and branch form substrate for accumulation of Thrombolite sub-facies. The black line locates the upper cross section 
Table 2 Main characteristics of facies associations in stratigraphic order from base to top

\begin{tabular}{|c|c|c|c|c|c|}
\hline Facies associations & Facies (subfacies) & $\begin{array}{l}\text { Depositional environ- } \\
\text { ments }\end{array}$ & Thickness recorded & $\begin{array}{l}\text { Stratigraphic occur- } \\
\text { rence }\end{array}$ & Distribution \\
\hline $\begin{array}{l}\text { Bedded marginal } \\
\text { lacustrine }\end{array}$ & $\begin{array}{l}\text { Cross-bedded peloidal } \\
\text { packstone-grainstone } \\
\text { Calcareous sandstone }\end{array}$ & $\begin{array}{l}\text { Marginal hypersaline } \\
\text { lacustrine }\end{array}$ & $4.50-10 \mathrm{~m}$ & Cypris Freestone & Throughout study area \\
\hline Hypersaline lacustrine & $\begin{array}{l}\text { Evaporite (vuggy and } \\
\text { breccia) } \\
\text { Gypsiferous peloidal } \\
\text { packstone }\end{array}$ & $\begin{array}{l}\text { Marginal hypersaline } \\
\text { lacustrine }\end{array}$ & $0-8.70 \mathrm{~m}$ & Broken Beds & $\begin{array}{l}\text { Dungy Head, West } \\
\text { Lulworth Cove, Fos- } \\
\text { sil Forest, Mupe Bay, } \\
\text { Worbarrow Tout, } \\
\text { Fishermen's Ledge, } \\
\text { Durlston Head }\end{array}$ \\
\hline $\begin{array}{l}\text { Mounded marginal } \\
\text { lacustrine }\end{array}$ & $\begin{array}{l}\text { Intraclastic peloidal } \\
\text { packstone-grainstone } \\
\text { Microbialite (stromato- } \\
\text { lite and thrombolite) } \\
\text { Burrow boundstone }\end{array}$ & $\begin{array}{l}\text { Marginal brackish } \\
\text { lacustrine }\end{array}$ & $1 \mathrm{~cm}$ to $5.90 \mathrm{~m}$ & $\begin{array}{l}\text { Soft Cap } \\
\text { Hard Cap } \\
\text { Skull Cap }\end{array}$ & Throughout study area \\
\hline Emergent & $\begin{array}{l}\text { Carbonaceous marl } \\
\text { Conglomerate }\end{array}$ & $\begin{array}{l}\text { Soils formed in } \\
\text { semi-arid climate } \\
\text { Mediterranean-type }\end{array}$ & $0-60 \mathrm{~cm}$ & $\begin{array}{l}\text { Cypris Freestone } \\
\text { Great Dirt Bed } \\
\text { Lower Dirt Bed } \\
\text { Basal Dirt Bed }\end{array}$ & Throughout study area \\
\hline Sub-littoral lacustrine & $\begin{array}{l}\text { Wackestone to fine } \\
\text { grainstone }\end{array}$ & $\begin{array}{l}\text { Sub-littoral brackish } \\
\text { lacustrine }\end{array}$ & $0-1.20 \mathrm{~m}$ & Transition Bed & $\begin{array}{l}\text { Portesham Q., Poxwell } \\
\text { Q., Chalbury } \\
\text { Hell's Bottom, } \\
\text { Swanworth Q., } \\
\text { Fishermen's Ledge, } \\
\text { Durlston Head } \\
\text { God Nore, Lawnshed } \\
\text { Q., Portland Bill }\end{array}$ \\
\hline
\end{tabular}

they should be referred to as thrombolites originating in brackish-water environments. Perry (1994) supported this idea and interpreted calcite cements coating phytoclasts as more evidence for a freshwater origin. Radley's (2002) work on mollusc assemblages showed that due to the low diversity of gastropod species and the mixing of low-salinity and marine species (considered to have been brought into the system via rare marine incursions), the environment was most likely a closed brackish-water system that was periodically saline marine. Supporting this are the rare occurrences of small benthic foraminifera within the packstone-grainstones of this study.

\section{Hypersaline water phase}

The upper part of the Mupe Member is considered to have been deposited in a more closed lacustrine system of Talbot and Allen (1996) or an underfilled lake type of Bohacs et al. (2000), as indicated by the evaporites and the preserved biota. Figure 23 illustrates the proposed depositional setting of a low-relief margin of this hypersaline, closed-lake. This is based on facies interpretation and a comparison with a modern-day analogue, the northern arm (Gunnison Bay) of the Great Salt Lake, Utah, USA (Chidsey et al. 2015; pers. obs. Gallois 2013).
The Great Salt Lake is divided into a closed, hypersaline, northern arm called Gunnison Bay (240-260 ppt) and a southern arm called Gilbert Bay (120-140 ppt), with freshwater input via four major river systems (Chidsey et al. 2015). In this northern part, microbialites are present but because of the extreme salinity (close to the halite-saturation point, Chidsey et al. 2015), today they are dead and lithified. These microbialites are covered by ooids and microbial intraclasts. Additionally, halite hopper crystals are crystallising on the surface water, sinking when too heavy to float, and are deposited on the lake floor as centimetre-thick salt deposits (Baskin 2014). Consequently, halite crystals can be found encrusted on the surface of the dead microbialites (Chidsey et al. 2015).

The facies model for the upper part of the Mupe Member indicates the lower part of the Cypris Freestone beds as being deposited within a shallow lake margin. This facies model comprises the Hypersaline lacustrine and Bedded marginal lacustrine facies associations. In the littoral to Sub-littoral zones of the lake, cross-bedded, coarse-grained facies accumulated in moderate- to high-energy conditions as indicated by the peloidal grainstones and the presence of well-sorted intraclasts and ooids that were deposited in dunes and ripples. The organic-rich interbeds (Fig. 3, Table 1) are rare throughout the studied area but may be seen 


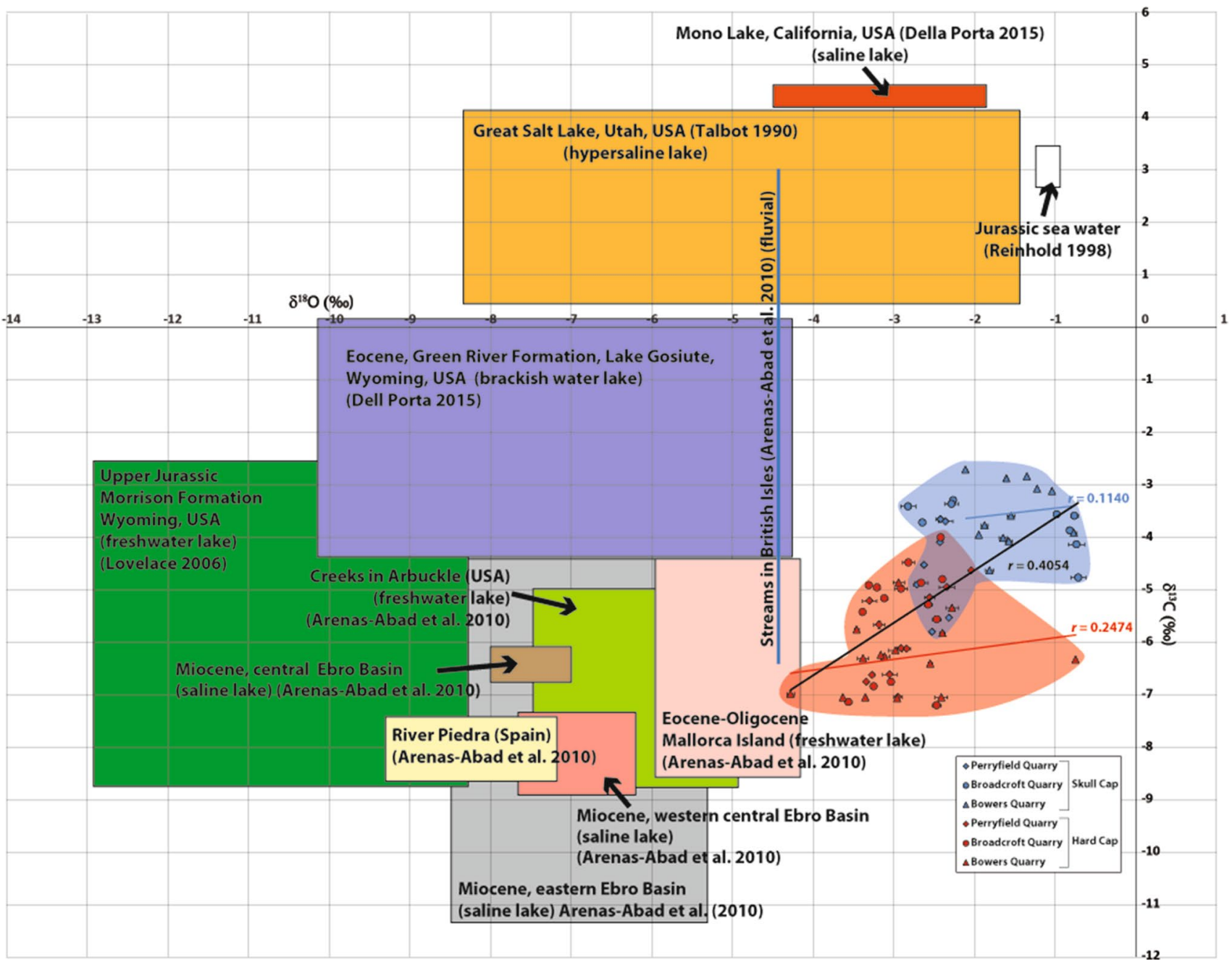

Fig. 19 Cross-plot of $\delta^{18} \mathrm{O}$ vs. $\delta^{13} \mathrm{C}$ stable isotope data of the Intraclastic peloidal packstone-grainstone facies in the Skull and Hard Cap units compared with data from non-marine carbonates by Talbot (1990), Lovelace (2006), Arenas-Abad et al. (2010) and Della Porta
(2015). Values from Arenas-Abad et al. (2010) were measured on fluvial carbonates; and from Talbot (1990) and Della Porta (2015) on present-day lake deposits on the Isle of Portland at Broadcroft Quarry, God Nore, King Barrow Quarries and Perryfield Quarry, and are thought to have been deposited in deeper waters from reworked nearby palaeosoils. The evidence of evaporite crystals as calcite or sediment pseudomorphs after gypsum, anhydrite and halite indicates arid climatic conditions and hypersaline waters. The presence of halite pseudomorphs on the top surfaces of beds suggests increasingly arid conditions and desiccation towards the top of the beds (Talbot and Allen 1996). Possible temporary and local freshwater input via river systems provided occasional siliciclastic material from the land that led to the deposition of the quartz-rich Calcareous sandstone facies. Rather more localised and closed areas within this lake provided the conditions for the deposition of the Evaporite facies (Evaporite vuggy sub-facies). Evaporite deposits were formerly more extensive than they appear at outcrop today, due to their dissolution, and this led to the formation of the Evaporite breccia sub-facies, interpreted as an evaporite collapse breccia (cf. West 1975). In the deepest part (i.e. sub-littoral zone) of the lake, the deposition of fine-grained facies is inferred (Sub-littoral lacustrine facies association) as for the previous facies model. The absence of microbial activity can be explained by two possible processes: either a rise in lake level (i.e. flooding) or a change in the chemistry of the water. A rise in lake level needs to be just enough to stop microbial growth and to be associated with a higher sedimentation rate (sediment input became greater than the growth rate) but not so high as to fill deeper lake areas. This is interpreted from the observations in the modern-day Great Salt Lake (Utah, USA) where microbialites are never found beyond $4 \mathrm{~m}$ water depth alongside coarse-grained facies. A change in the chemistry of the water 

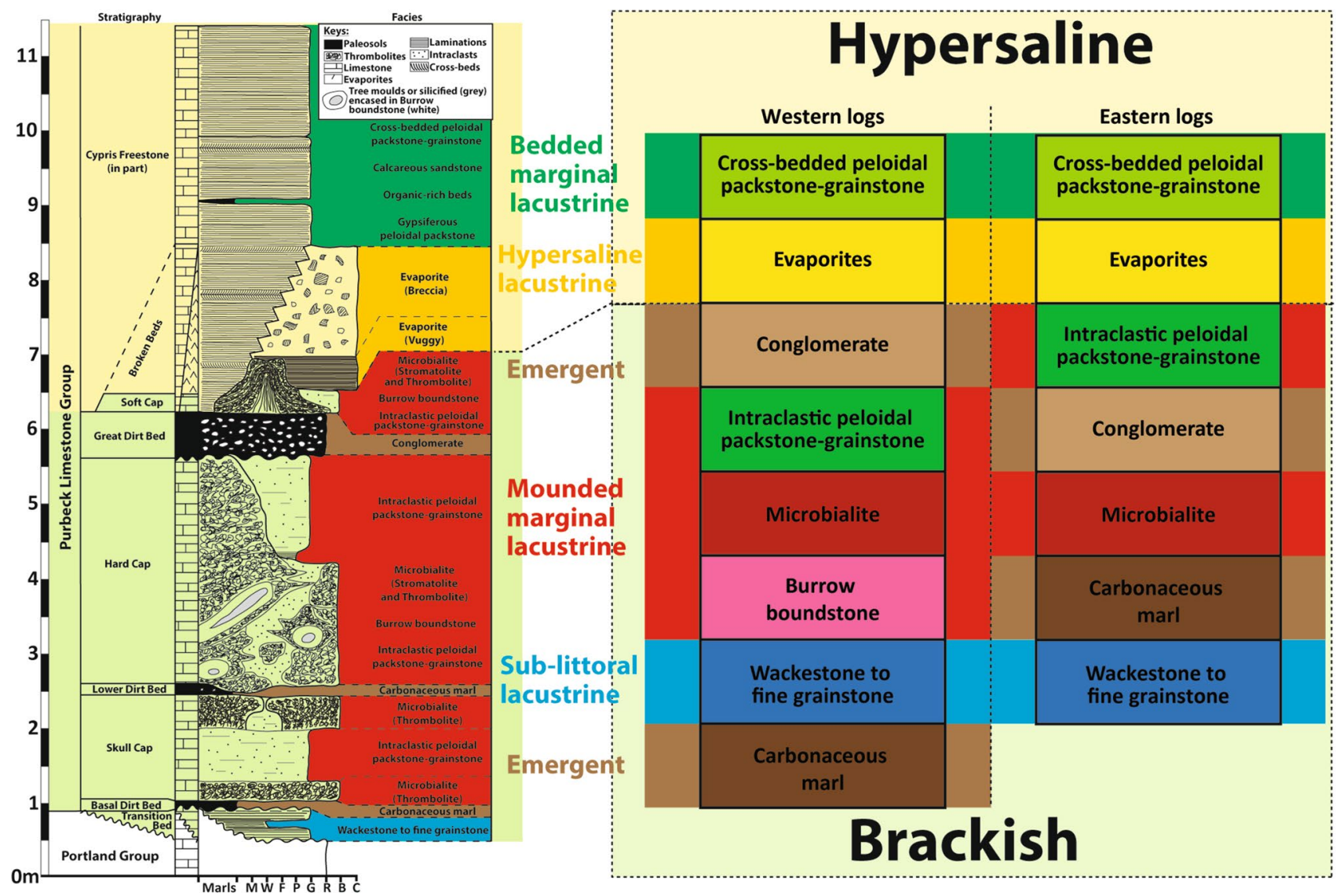

Fig. 20 Ideal sequences with facies associations and depositional environments together with the generalised log

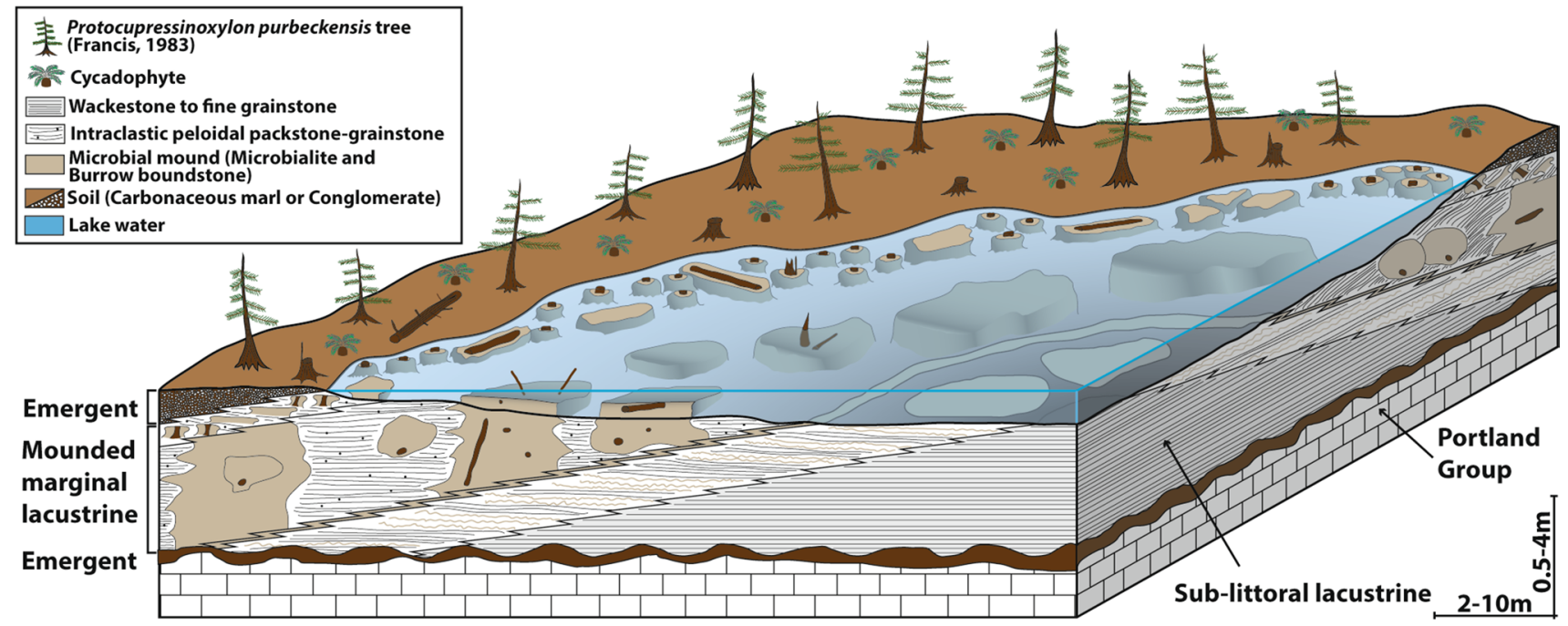

Fig. 21 Facies model for hypothetical brackish-water open-lake margin for the lower Mupe Member, based on the modern analogue Laguna Bacalar (Mexico)

could be due to geographical barriers that reduced flows and increased salinities, which would have provoked the death of the microbial community. This is interpreted from Dupraz et al.'s (2009) work that proposed that a lack of dissolved carbo associated with either a lack or excess of sediment is deleterious to microbial health and growth. However, 

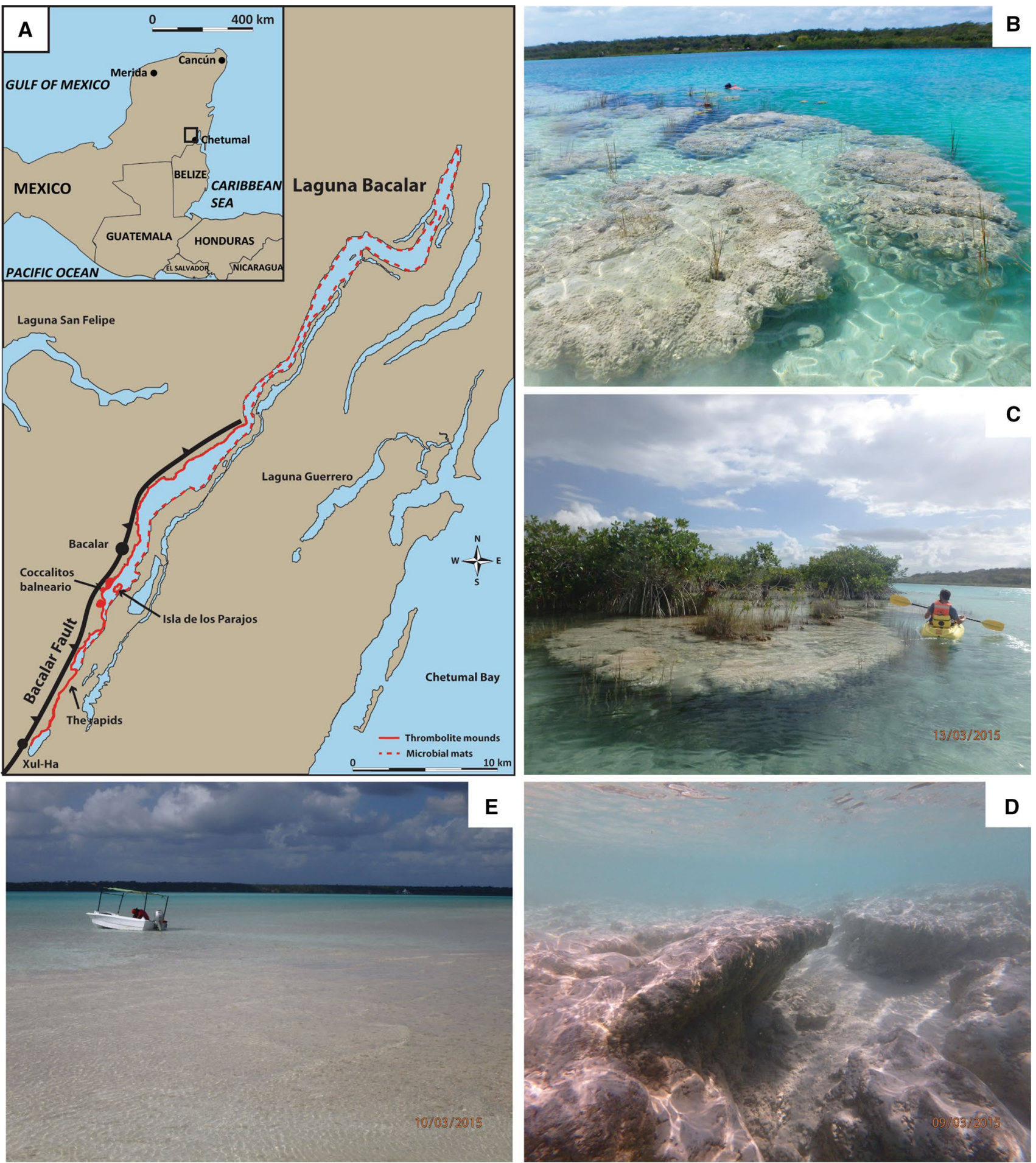

Fig. 22 Laguna Bacalar, Yucatan Peninsula, Mexico. a Map of the lake with microbialite occurrence in red (after Gischler et al. 2008, 2011). b, c Flat-topped lake margin mounds, south of The Rapids. d

Underwater view of lake margin flat-topped ledge mounds, south of The Rapids. e Shallow microbial mats, western lake shore

the peloidal packstone-grainstone facies described in this the previous facies model lacking microbial intraclasts and facies model are typical of marginal areas and are similar to with more ooids. This indicates that the carbonate saturation 


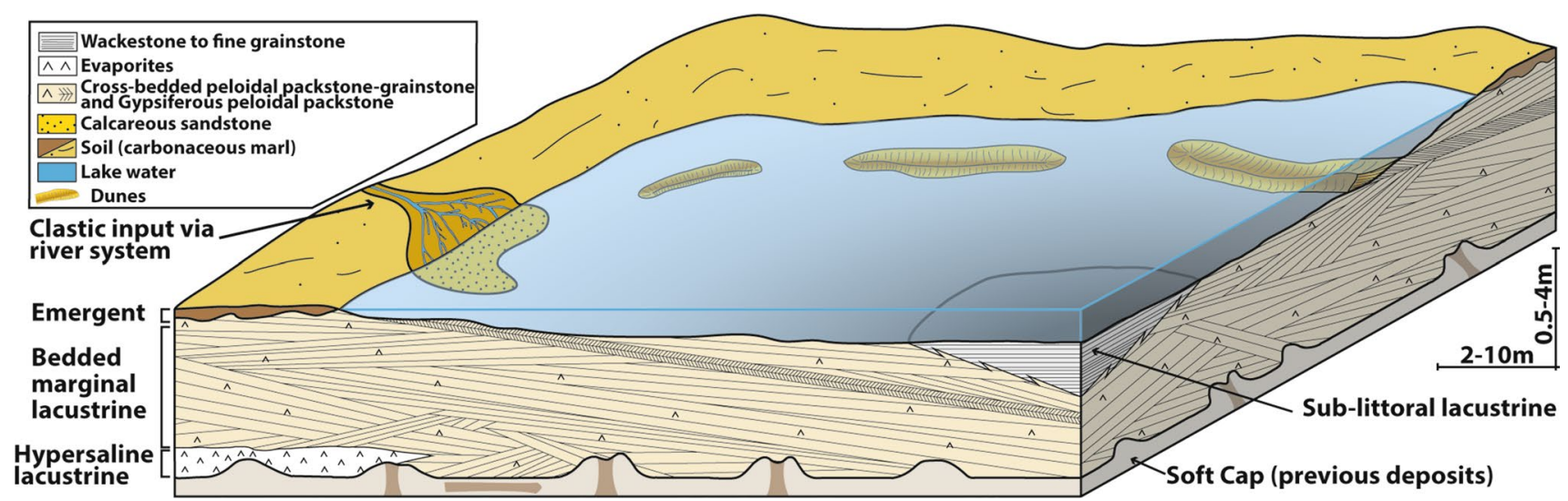

Fig. 23 Facies model for regressive hypersaline water lake margin for the upper part of the Mupe Member. Note that the upper palaeosoil is only locally developed compared with the previous model for the lower Mupe Member

probably remained the same or slightly higher, and that an increase in salinity, as indicated by the appearance of evaporite pseudomorphs, is the more likely cause of the death of the microbialites.

In contrast to the brackish-water facies model (Fig. 21), the hypersaline model (Fig. 23) is in agreement with most of the previous interpretations of depositional environments for the Mupe Member and, in particular, with West's (1975) interpretation of hypersaline conditions. Radley's (2002) interpretation of a closed lacustrine system, based on mollusc assemblages (see above), is also consistent with data presented in this study and the hypersaline facies model of Fig. 23.

\section{Discussion}

\section{Microbialites as palaeoenvironmental indicators?}

Della Porta (2015) compared lacustrine build-ups of a number of modern lakes (Great Salt Lake in Utah, Pyramid Lake in Nevada, and Mono Lake in California in the USA) and ancient lacustrine deposits (Green River Formation, Uinta Basin in Utah and Lake Gosiute in Wyoming in the USA and Ries Crater Lake in Germany) and concluded that internal fabrics of such build-ups are not specific to different lacustrine environments and therefore cannot be used as palaeoenvironmental indicators. By contrast, Jahnert and Collins (2011, 2012) studied the microbial deposits in modern-day hypersaline marine Shark Bay (Hamelin Pool, Western Australia) and Chidsey et al. (2015) studied the ancient microbial deposits of the Green River Formation (Uinta Basin, Utah, USA) compared to its modern analogue, the Great Salt Lake (Utah, USA). Both studies showed an environmental control on microbialite development and demonstrated that a specific internal fabric reflects a specific water depth and a specific margin type, with stromatolites found in the shallowest part and in low gradient margins and thrombolites in deeper waters and in steeper gradient margins. In the present study, thrombolitic and stromatolitic internal fabrics (cf. Riding 2011) are identified and interpreted to be deposited in a brackish-water lake, compared to modern analogues.

The internal fabrics of the Purbeck microbial facies described in this study show similarities with a range of published data worldwide. Thrombolitic and stromatolitic internal fabrics in the Purbeck limestones are very similar to those found in modern and ancient environments, and five among many others are mentioned here:

The freshwater lake at Laguna Bacalar (Yucatan Peninsula, Mexico, Gischler et al. 2008, 2011) contains thrombolites with their internal fabrics made of heads of upwardradiating filament moulds incorporating the surrounding sediments and fossils.

The hypersaline lake at Great Salt Lake (Utah, USA, Chidsey et al. 2015; Della Porta 2015) contains leiolites to thrombolites (Della Porta 2015) that comprise abundant calcitic spherulites linked with acicular cements and/or microbial filaments (Chidsey et al. 2015) and that can incorporate peloids, detrital grains, ooids, or even bird feathers; the external part is usually encrusted with tubes of brine-fly larvae (Post 1977; Chidsey et al. 2015; Della Porta 2015).

The marine hypersaline lagoon at Hamelin Pool (Shark Bay, Western Australia, Jahnert and Collins 2011, 2012) contains stromatolitic laminated microfabrics of smooth and colloform mounds and thrombolitic clotted microfabrics of pustular domes (Jahnert and Collins 2011, 2012).

The alkaline Mono Lake (California, USA, Della Porta 2015) contains metre-scale pinnacles composed in the central layers of leiolitic and clotted peloidal micrite, dendrites and calcitic spherulites; they are coated in the external layers 
with dense micrite laminae, microsparitic crusts and clotted micrite.

The Eocene brackish-water lake of the Green River Formation (Uinta Basin, Utah, USA, Chidsey et al. 2015; Della Porta 2015) contains microbialites with four main internal microstructures: stromatolitic agglutinated made of irregular coarse-grained (peloids, quartz grains and intraclasts) laminae; stromatolitic agglutinated dendritic composed of an alternation of coarse-grained (as for the previous fabric) and dendritic laminae; stromatolitic fine-grained composed of laterally extensive laminae (from metres to tens of metres), and thrombolitic microfabrics characterised by a clotted structure with a micritic matrix incorporating ooids, peloids and quartz grains (Sarg et al. 2013).

This shows that microbial deposits similar but not identical to that of the Purbeck have been found in a range of salinities (from freshwater to hypersaline marine) and all kinds of climate settings (Mediterranean-type to tropical). Therefore, based only on their internal fabrics, microbialites are not thought to be useful as palaeoenvironmental indicators. Interpretation requires the integration of palaeontological, petrographic (stable isotopes) data from penecontemporaneous facies together with comparisons with modern analogues. As mentioned by Della Porta (2015), integration of mound internal fabrics, external morphologies and distribution and their relationships with surrounding facies is critical to enable microbial deposits to be used as palaeoenvironmental indicators.

\section{Depositional environments}

This study indicates that the palaeoenvironments were initially brackish-water lacustrine as opposed to the hypersaline lagoons as interpreted by West $(1975,1979)$ and by Francis (1982). In addition, the two new facies models that depict the two depositional environments proposed in this study indicate that the hypersaline conditions interpreted by West (1975) only appeared in the second half of the Mupe Member (above the Soft Cap). The former brackish-water phase can be classified as a balanced-fill lake type of Bohacs et al. (2003) or an open lake of Talbot and Allen (1996), and the later hypersaline phase as an under-filled lake type of Bohacs et al. (2003) or a closed lake of Talbot and Allen (1996). The transition between the two depositional environments in the Purbeck is sharp, and forms one bedding plane between the Soft Cap and the Cypris Freestone as observed at the Fossil Forest, Lulworth. Here, thinly bedded evaporitic beds overlie microbial mounds and inter-mound facies (Figs. 1 and 23). The thinly bedded evaporitic beds drape the original topography of the mounds and there is no evidence of erosion on this surface. Such a transition is similar to that of modernday salt-pans where, due to evaporation after closure of the water body, the deposition of gypsum and halite crusts has resulted in a sharp vertical transition between brackish deposits and evaporitic beds (e.g. Lowenstein and Hardie 1985; Chidsey et al. 2015).

In the lower part of the Purbeck Limestone Group of Dorset, the transition between the brackish and hypersaline environments is sharp, so a climatic control seems unlikely to be the driving mechanism. This is supported by palaeoclimate studies that propose that arid conditions prevailed during the Late Jurassic, from the late Kimmeridgian (hudlestoni zone) through to the early Berriasian, with its climax during the deposition of the lower Purbeck beds (Hallam 1993; Hesselbo et al. 2009). As a consequence, channel avulsion (Allen 1965) or tectonically driven change in discharge (Twidale 1971) appear to be the best candidates that might control such a sharp transition. Although no clear evidence for synsedimentary tectonics has been published for the lower Purbeck beds, fluvial input was hypothesised by Underhill (2002) to be through the relay ramp linking the Ridgeway and Purbeck Faults (Fig. 1) and this is further supported by data in this paper (Table 1). A change in the palaeotopography either due to synsedimentary tectonics or to channel avulsion on the footwall blocks or on the relay ramp could have resulted in a river system diversion that would have interrupted the freshwater input into the lake.

\section{Conclusions}

This study demonstrates the importance of studying the details of facies and their transitions for the interpretation of shallow lacustrine deposits. Such data are used, together with modern analogues, to erect new facies models for lacustrine carbonates. The main conclusions from this work are as follows:

The study of the Mupe Member of the Purbeck Limestone Group results in ten newly described facies, grouped into five facies associations, all interpreted as marginal deposits in an earlier brackish and a later hypersaline shallow lake.

The Wackestone to fine grainstone facies is exclusive to the Transition Bed locally deposited at the base of the Mupe Member and is interpreted to represent deeper water deposits in a brackish-water lake. The Microbialite facies composed of the Stromatolite and Thrombolite sub-facies and together with an unusual Burrow boundstone facies form microbial mounds that are closely associated with the intermound Intraclastic peloidal packstone-grainstone facies and together with the mounds are found in the Skull, Hard and Soft Cap beds. These facies are interpreted to represent shallow-water deposits formed on the margins of a brackishwater lake. The sub-lacustrine facies are overlain by palaeosoils of the Carbonaceous marl and Conglomerate facies developed under a semi-arid, Mediterranean-type climate. The Cross-bedded peloidal packstone-grainstone facies 

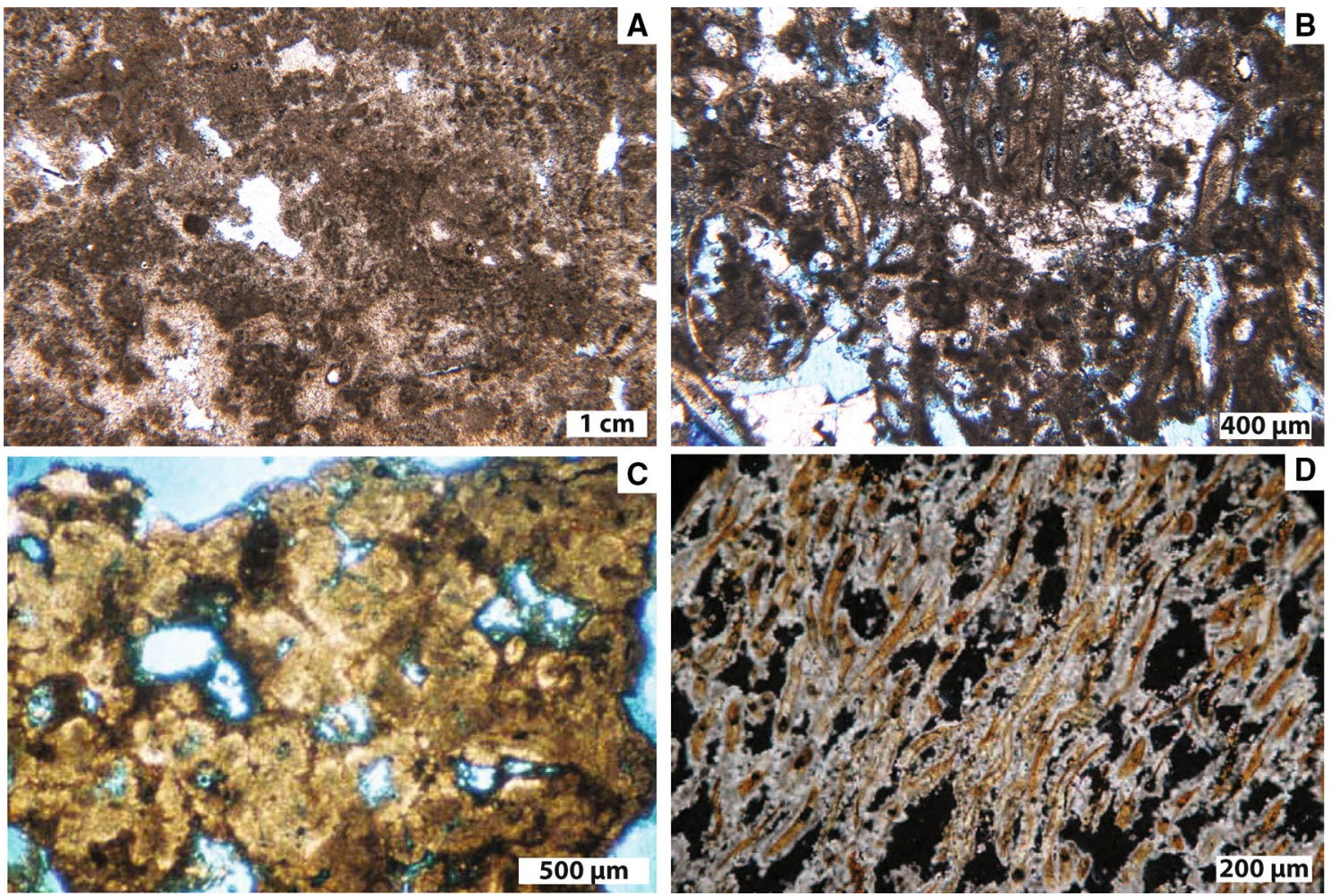

Fig. 24 Microphotographs comparing thrombolitic internal fabrics from Purbeck limestone mounds, Great Salt Lake (Utah, USA) and Laguna Bacalar (Mexico). a Clotted texture and cement fringes under PPL from Purbeck (POQ6, Hard Cap, Poxwell Quarry, 50³9'3.84"N; $\left.2^{\circ} 21^{\prime} 52.12^{\prime \prime} \mathrm{W}\right)$. b Microbial filaments, ostracods and peloids under

constitutes the main facies of the overlying Cypris Freestone beds and is interbedded with the Gypsiferous peloidal packstone and Calcareous sandstone facies together with Vuggy and Breccia sub-facies of the Evaporite facies. Together, these facies were formed in a hypersaline shallow lacustrine margin environment.

Microbial mounds are particularly useful indicators of palaeoenvironments, but only when macro- and micro-scale characterisations are integrated with a full description and interpretation of penecontemporaneous facies and biotas.

Similar microbial fabrics of stromatolites and thrombolites are found in modern analogues to the Purbeck limestones such as the freshwater Laguna Bacalar (Mexico, Fig. 24), the hypersaline Great Salt Lake (Utah, USA, Fig. 24) and ancient analogues such as the brackish-water Green River Formation (Eocene) of the Uinta Basin (Utah, USA).

The small-scale characterisation of the vertical facies transition from the earlier brackish to the later hypersaline lake showed that the boundary is marked by a sharp contact where hypersaline, locally evaporitic, deposits are directly overlying microbial mounds. This suggests that the change may have occurred rapidly, most likely due to an extensional

PPL from Purbeck (GN4, Hard Cap, God Nore, 50³1'31.41"N; $\left.2^{\circ} 26^{\prime} 22.51^{\prime \prime} \mathrm{W}\right)$. c Clotted texture and early cements under PPL from Great Salt Lake (Utah, USA, Chidsey et al. 2015). d Microbial filaments and early cements under XPL from Laguna Bacalar (Yucatan Peninsula, Mexico, Castro-Contreras et al. 2014)

tectonic event (e.g. fault movement, tilting) or a channel avulsion resulting in a reduction in the fluvial discharge into the lake.

Acknowledgements This research was funded by BP Exploration Operating Company Ltd and Baker Hughes Ltd and the authors wish to thank current and former employees, I. Billing (BP, UK), T. Sabato Ceraldi (BP, UK) and S. Krueger (Baker Hughes, Germany) and B. Vining (Baker Hughes, UK) for their help throughout the project and approvals for the publication of this work. Thanks to V. Dharmarajah (RHUL, UK), who performed the $\mathrm{C}$ and $\mathrm{O}$ stable isotope analyses during her MSc summer project and to D. Lowry (RHUL, UK) for his help in undertaking these analyses. We are very grateful to the quarry managers on the Isle of Portland, M. Godden (Albion Stone) and A. Jackson (Portland Stone Firms), who always granted us access to the quarries. The authors would also like to thank the two reviewers André Strasser and Paul Wright and Maurice Tucker for their very constructive comments and suggestions that improved this manuscript.

Open Access This article is distributed under the terms of the Creative Commons Attribution 4.0 International License (http://creativeco mmons.org/licenses/by/4.0/), which permits unrestricted use, distribution, and reproduction in any medium, provided you give appropriate credit to the original author(s) and the source, provide a link to the Creative Commons license, and indicate if changes were made. 


\section{References}

Ainsworth RB, Hasiotis ST, Amos KJ, Krapf CBE, Payenberg THD, Sandstrom ML, Vakarelov BK, Lang SC (2012) Tidal signatures in an intracratonic playa lake. Geology 40:607-610

Allen JR (1965) A review of the origin and characteristics of recent alluvial sediments. Sedimentology 5:89-191

Anderson FW (1985) Ostracod faunas in the Purbeck and Wealden of England. J Micropalaeontol 4:1-67

Anderson FW, Bazley RAB (1971) The Purbeck Beds of the Weald (England). Bull Inst Geol Sci, London, p 34

Arenas-Abad C, Vázquez-Urbez M, Pardo-Tirapu G, Sancho-Marcén C (2010) Fluvial and associated carbonate deposits. In: AlonsoZarza AM, Tanner LH (eds) Carbonates in continental settings, vol 61. Developments in Sedimentology. Elsevier, Amsterdam, pp 133-175

Arkell WJ (1933) The Jurassic system in Great Britain. Oxford University Press, Oxford

Arkell WJ (1941) The gastropods of the Purbeck Beds. Q J Geol Soc 97:79-128

Arkell WJ (1947) The geology of the country around Weymouth, Swanage, Corfe \& Lulworth. HM Stationery Office, Richmond

Austen JH (1852) A guide to the geology of the Isle of Purbeck, and the south-west coast of Hampshire. W Ship

Barker D, Brown CE, Bugg SC, Costin J (1975) Ostracods, land plants, and charales from the basal Purbeck beds of Portesham Quarry, Dorset. Palaeontology 18:419-436

Baskin RL (2014) Occurrence and spatial distribution of microbial bioherms in Great Salt Lake. PhD thesis, University of Utah

Bohacs KM, Carroll AR, Neal JE, Mankiewicz PJ (2000) Lake-basin type, source potential, and hydrocarbon character: an integratedsequence-stratigraphic-geochemical framework. In: GierlowskiKordesch EH, Kelts KR (eds) Lake basin through space and time, vol 46. American Association of Petroleum Geologists studies in geology. AAPG, Tulsa, pp 3-34

Bohacs KM, Carroll AR, Neal JE (2003) Lessons from large systemsthresholds, nonlinearity, and strange attractors. In: Chan MA, Archer AW (eds) Extreme depositional environments: mega end members in geologic time, vol 370. Geol soc Am spec pap, pp $75-90$

Bosence DWJ (1987) Portland and Purbeck Formations of the Isle of Portland. In: Riding R (ed) 4th Symposium on Fossil Algae, Excursions Guide, Cardiff

Bristow H (1857) Comparative vertical sections of the Purbeck strata of Dorsetshire. Geological Survey Vertical Sections 22

Brown PR (1963) Algal limestones and associated sediments in the basal Purbeck of Dorset. Geol Mag 100:565-573

Brown PR (1964) Petrography and origin of some Upper Jurassic beds from Dorset, England. J Sediment Res 34:254-269

Buckland W, De La Bèche HT (1835) On the geology of the neighbourhood of Weymouth and the adjacent parts of the Coast of Dorset. Trans Geol Soc Lond 4:1-46

Burgess P (2016) Identifying ideal stratigraphic cycles using a quantitative optimization method. Geology 44:443-446

Bustillo MA (2010) Silicification of continental carbonates. Dev Sedimentol 62:153-178

Carroll AR, Bohacs KM (1999) Stratigraphic classification of ancient takes: balancing tectonic and climatic controls. Geology 27:99-102

Casey R (1963) The dawn of the Cretaceous period in Britain. Bull South-East Union Sci Soc 117:1-15

Castro-Contreras SI, Gingras MK, Pecoits E, Aubet NR, Petrash D, Castro-Contreras SM, Dick G, Planavsky N, Konhauser KO (2014) Textural and geochemical features of freshwater microbialites from Laguna Bacalar, Quintana Roo, Mexico. Palaios 29:192-209

Chacón-Baca E, Beraldi-Campesi H, Cevallos-Ferriz S, Knoll A, Golubic S (2002) 70 Ma nonmarine diatoms from northern Mexico. Geol 30:279-281

Clements RG (1973) A study of certain non-marine Gastropoda from the Purbeck Beds of England. PhD thesis, University of Hull

Clements RG (1993) Type-section of the Purbeck Limestone Group, Durlston Bay, Swanage, Dorset. Proc Dorset Nat Hist Archaeol Soc 114:181-206

Cope JCW, Duff KL, Parsons CF, Torrens HS, Wimbledon WA, Wright JK (1980) A correlation of Jurassic rocks in the British Isles: part two: Middle and Upper Jurassic. Geo Soc Lond Spec Rep, vol 15. Blackwell Scientific Publications, Hoboken

Cope J, Ingham JK, Rawson P (1992) Atlas of palaeogeography and lithofacies. Geol Soc London

Damon R (1860) Handbook to the geology of Weymouth and the Island of Portland: with notes on the natural history of the coast and neighbourhood, Stanford

Dashtgard SE, Gingras MK (2012) Marine invertebrate neoichnology. In: Knaust D, Bromley RG (eds) Trace fossils as indicators of sedimentary environments, vol 64. Development in sedimentology. Elsevier, Amsterdam, pp 273-295

Della Porta G (2015) Carbonate buildups in lacustrine, hydrothermal and fluvial settings: comparing depositional geometry, fabric types and geochemical signature. In: Bosence D, Gibbons K, Le Heron DP, Morgan WA, Pritchard T, Vining BA (eds) Microbial carbonates in space and time: implications for global exploration and production. Geol Soc Lond Spec Publ 418:17-68

Dharmarajah V (2015) Sequences and layering in lacustrine carbonates; Purbeck Limestone, Wessex Basin. MSc thesis, Royal Holloway University of London

Dupraz C, Pattisina R, Verrecchia E (2006) Translation of energy into morphology: simulation of stromatolite morphospace using a stochastic model. Sediment Geol 185:185-203

Dupraz C, Reid RP, Braissant O, Decho AW, Norman RS, Visscher PT (2009) Processes of carbonate precipitation in modern microbial mats. Earth Sci Rev 96:141-162

Fisher O (1856) On the Purbeck strata of Dorsetshire. Trans Camb Philos Soc 9:555-581

Fitton WH (1827) Observations on some of the strata between the Chalk and the Oxford Oolite, in the south-east of England. Trans Geol Soc Lond 2:103-388

Francis JE (1982) The Fossil Forest of the basal Purbeck Formation (Upper Jurassic) of Dorset, southern England. Palaeobotanical and palaeoenvironmental investigations. PhD thesis, University of Southampton

Francis JE (1983) The dominant conifer of the Jurassic Purbeck Formation, England. Palaeontology 26:277-294

Francis JE (1984) The seasonal environment of the Purbeck (Upper Jurassic) fossil forests. Palaeogeogr Palaeoclim Palaeoecol 48:285-307

Francis JE (1986) The calcareous paleosols of the basal Purbeck Formation (Upper Jurassic), southern England. In: Wright VP (ed) Paleosols. Blackwell Oxford, Oxford, pp 112-138

Gallois A (2013) Late Jurassic lacustrine carbonates; a multi-scale analysis of the Mupe Member (Purbeck Limestone Group) of the Wessex Basin, UK. PhD thesis, Royal Holloway University of London

Gierlowski-Kordesch EH (2010) Lacustrine carbonates. In: AlonsoZarza AM, Tanner LH (eds) Carbonates in continental settings. Facies, environments and processes, vol 61. Elsevier, Amsterdam, pp 1-101

Gischler E, Gibson MA, Oschmann W (2008) Giant Holocene freshwater microbialites, Laguna Bacalar, Quintana Roo, Mexico. Sedimentol 55:1293-1309 
Gischler E, Golubić S, Gibson MA, Oschmann W, Hudson JH (2011) Microbial mats and microbialites in the freshwater Laguna Bacalar, Yucatan Peninsula, Mexico. In: Reitner J, Quéric N-V, Arp $\mathrm{G}$ (eds) Advances in stromatolite geobiology, vol 131. Springer, Berlin, pp 187-205

Hallam A (1993) Jurassic climates as inferred from the sedimentary and fossil record. Philos Trans R Soc Lond 341:287-296

Hanor JS (2000) Barite-celestine geochemistry and environments of formation. Rev Mineral Geochem 40:193-275

Hanor JS (2004) A model for the origin of large carbonate-and evaporite-hosted celestine $\left(\mathrm{SrSO}_{4}\right)$ deposits. J Sediment Res 74:168-175

Hesselbo SP, Deconinck J-F, Huggett JM, Morgans-Bell HS (2009) Late Jurassic palaeoclimatic change from clay mineralogy and gamma-ray spectrometry of the Kimmeridge Clay, Dorset, UK. J Geol Soc 166:1123-1133

Horne DJ (1995) A revised ostracod biostratigraphy for the PurbeckWealden of England. Cretac Res 16:639-663

Horne DJ (2002) Ostracod biostratigraphy and palaeoecology of the Purbeck Limestone Group in southern England. Spec Pap Palaeontol 68:53-70

Horne DJ (2004) Jurassic/Cretaceous of Durlston Bay, Dorset. In: Siveter DJ, Lord AR (eds) Fieldguide for the Thirteenth International Symposium on Ostracoda. British Micropalaeontological Society, Chatham 10:46-56

House MR (1969) The Dorset coast from Poole to the Chesil Beach. 2nd Edition. Geologists' Association Guides. Geologists' Association 22

Jahnert RJ, Collins LB (2011) Significance of subtidal microbial deposits in Shark Bay, Australia. Marine Geol 286:106-111

Jahnert RJ, Collins LB (2012) Characteristics, distribution and morphogenesis of subtidal microbial systems in Shark Bay, Australia. Marine Geol 303-306:115-136

Kennish MJ (1986) Ecology of Estuaries: physical and chemical aspects, vol 1. CRC Press Inc, Boca Raton

Knaust D, Bromley RG (2012) Trace fossils as indicators of sedimentary environments. Elsevier, Amsterdam

Lake SD (1985) The structure and evolution of the Wessex Basin. PhD thesis, University of Durham

Leggitt VL, Loewen MA (2002) Eocene Green River Formation "Oocardium tufa" reinterpreted as complex arrays of calcified caddisfly (Insecta: trichoptera) larval cases. Sediment Geol 148:139-146

Leng MJ, Marshall JD (2004) Palaeoclimate interpretation of stable isotope data from lake sediment archives. Q Sci Rev 23:811-831

Leo RF, Barghoorn ES (1976) Silicification of wood. Botanical Mus Leafl Harv Univ 25:1-47

Lovelace DM (2006) An Upper Jurassic Morrison Formation fireinduced debris flow: taphonomy and paleoenvironment of a sauropod (sauropoda: Supersaurus vivianae) locality, east-central Wyoming. N M Mus Nat Hist Sci Bull 36:47-64

Lowenstein TK, Hardie LA (1985) Criteria for the recognition of saltpan evaporites. Sedimentology 32:627-644

Mann KH, Lazier JRN (1991) Dynamics of marine ecosystem. Blackwell Science

Manconi R, Pronzato R (2008) Global diversity of sponges (Porifera: Spongillina) in freshwater. Hydrobiol 595:27-33

Mortimer CH (2004) Lake Michigan in motion: responses of an inland sea to weather, earth-spin, and human activities. University of Wisconsin Press, Madison

Mortimer CH, Fee EJ (1976) Free surface oscillations and tides of Lakes Michigan and Superior. Philos Trans R Soc Lond 281:1-61

Paik IS (2005) The oldest record of microbial-caddisfly bioherms from the Early Cretaceous Jinju Formation, Korea: occurrence and palaeoenvironmental implications. Palaeogeogr Palaeoclim Palaeoecol 218:301-315

Pérez L, Bugja R, Lorenschat J, Brenner M, Curtis J, Hoelzmann P, Islebe G, Scharf B, Schwalb A (2011) Aquatic ecosystems of the Yucatan Peninsula (Mexico), Belize, and Guatemala. Hydrobiology 661:407-433

Perry CT (1994) Freshwater tufa stromatolites in the basal Purbeck Formation (Upper Jurassic), Isle of Portland, Dorset. Geol J 29:119-135

Platt NH, Wright VP (1991) Lacustrine carbonates: facies models, facies distributions and hydrocarbon aspects. In: Anadón P, Cabrera L, Kelts K (eds) Lacustrine facies analysis. Spec Publ IAS 13: $57-74$

Post FJ (1977) The microbial ecology of the Great Salt Lake. Microb Ecol 3:143-165

Radley JD (2002) Distribution and palaeoenvironmental significance of molluscs in the Late Jurassic-Early Cretaceous Purbeck Formation of Dorset, southern England: a review. In: Milner AR, Batten DJ (eds) Life and environments in Purbeck times. Special Papers in Palaeontology. The Palaeontological Association 68: 41-52

Reinhold C (1998) Multiple episodes of dolomitization and dolomite recrystallization during shallow burial in Upper Jurassic shelf carbonates: eastern Swabian Alb, southern Germany. Sediment Geol 121:71-95

Renaut RW, Morley CK, Jones B (2002) Fossil hot-spring travertine in the Turkana Basin, northern Kenya: structure, facies, and genesis. In: Renaut RW, Ashley GM (eds) Sedimentation in continental rifts. Spec Publ SEPM 73:123-141

Riboulleau A, Schnyder J, Riquier L, Lefebvre V, Baudin F, Deconinck J-F (2007) Environmental change during the Early Cretaceous in the Purbeck-type Durlston Bay section (Dorset, southern England): a biomarker approach. Org Geochem 38:1804-1823

Riding R (1991) Calcareous algae and stromatolites. Springer, Berlin

Riding R (2011) Microbialites, stromatolites, and thrombolites. In: Reitner J, Thiel V (eds) Encyclopaedia of geobiology. Springer, Heidelberg, pp 635-654

Rusnak GA (1960) Some observations of recent oolites. J Sediment Res 30:471-480

Sager PE, Richman S, Harris HJ, Fewless G (1985) Preliminary observations on the seiche-induced flux of carbon, nitrogen and phosphorus in a Great Lakes coastal marsh. In: Prince HH, D'Itri FM (eds) Coastal Wetlands. Lewis Publishers, Chelsea, pp 59-65

Sarg JF, Suriamin H, Tänavsuu-Milkeviciene K, Humphrey JD (2013) Lithofacies, stable isotopic composition, and stratigraphic evolution of microbial and associated carbonates, Green River Formation (Eocene), Piceance Basin, Colorado. AAPG Bull 97:1937-1966

Siever R (1962) Silica solubility, $0-200{ }^{\circ} \mathrm{C}$, and the diagenesis of siliceous sediments. J Geol 70:127-150

Strahan A (1898) The Geology of the Isle of Purbeck and Weymouth. Memoirs of the Geological Survey, England and Wales

Strasser A, Davaud E (1983) Black pebbles of the Purbeckian (Swiss and French Jura): lithology, geochemistry and origin. Eclogae Geolog Helvetiae 76:551-580

Talbot MR (1990) A review of the palaeohydrological interpretation of carbon and oxygen isotopic ratios in primary lacustrine carbonates. Chem Geol Isot Geosci Sect 80:261-279

Talbot MR, Allen PA (1996) Lakes. In: Reading HG (ed) Sedimentary environments: processes, facies and Stratigraphy. Blackwell Publishing, Oxford, pp 83-124

Talbot MR, Kelts K (1990) Paleolimnological signatures from carbon and oxygen isotopic ratios in carbonates, from organic carbonrich lacustrine sediments. In: Katz BJ (ed) Lacustrine basin exploration: case studies and modern analogs. AAPG Mem 50:88-112 
Tanner LH (2010) Continental carbonates as indicators of paleoclimate. In: Alonso-Zarza AM, Tanner LH (eds) Carbonates in continental settings. Developments in sedimentology, vol 62. Elsevier, Amsterdam, pp 179-214

Trebitz AS (2006) Characterizing seiche and tide-driven daily water level fluctuations affecting coastal ecosystems of the Great Lakes. J Gt Lakes Res 32:102-116

Twidale CR (1971) Structural landforms: landforms associated with granitic rocks, faults and folded strata. Australian National University Press, Canberra

Underhill JR (2002) Evidence for structural controls on the deposition of the Late Jurassic-Early Cretaceous Purbeck Limestone Group, Dorset, southern England. In: Milner AR, Batten DJ (eds) Life and environments in Purbeck times. Spec Pap Palaeontol, vol 68. Palaeontogical Association London, pp 21-40

Underhill JR, Stoneley R (1998) Introduction to the development, evolution and petroleum geology of the Wessex Basin Geolog Soc Lond Spec Publ 133:1-18

Warren JK (2006) Evaporites: sediments, resources and hydrocarbons. Springer

Webster T (1826) Observations on the Purbeck and Portland Beds. Trans Geol Soc Lond 1:37-44

West IM (1960) On the occurrence of celestine in the caps and broken beds at Durlston Head, Dorset. Proc Geol Assoc 71:391-401

West IM (1961) Lower Purbeck beds of Swindon facies in Dorset. Nat 190:526

West IM (1964) Deformation of the incompetent beds in the Purbeck Anticline. Geol Mag 101:373
West IM (1975) Evaporites and associated sediments of the basal Purbeck Formation (Upper Jurassic) of Dorset. Proc Geol Assoc 86:205-225

West IM (1979) Sedimentary environments and diagenesis of Purbeck strata (Upper Jurassic-Lower Cretaceous) of Dorset UK. PhD thesis, Southampton University

West IM (1992) Contribution on Purbeck Group. In: Cope JCW, Ingham JK, Rawson PF (eds) Atlas of palaeogeography and lithofacies. Mem Geol Soc Lond, 13:124-126

West IM (2013) Purbeck Formation-facies and palaeoenvironments. http://www.southampton.ac.uk/ imw/purbfac.htm. Accessed July 2017

Westhead RK, Mather AE (1996) An updated lithostratigraphy for the Purbeck Limestone Group in the Dorset type-area. Proc Geol Assoc 107:117-128

Wimbledon WA, Hunt CO (1983) The Portland-Purbeck junction (Portlandian-Berriasian) in the Weald, and correlation of latest Jurassic-early Cretaceous rocks in southern England. Geol Mag 120:267-280

Chidsey TC, Vanden Berg MD, Eby DE (2015) Petrography and characterization of microbial carbonates and associated facies from modern Great Salt Lake and Uinta Basin's Eocene Green River Formation in Utah, USA. In: Bosence D, Gibbons K, Le Heron DP, Morgan WA, Pritchard T, Vining BA (eds) Microbial carbonates in space and time: implications for global exploration and production. Geol Soc Lond Spec Publ 418:261-286

Ziegler PA (1982) Geological Atlas of Western and Central Europe. Elsevier, Amsterdam 